UNIVERSIDADE DE SÃO PAULO

FFCLRP - DEPARTAMENTO DE PSICOLOGIA E EDUCAÇÃO

PROGRAMA DE PÓS-GRADUAÇÃO EM PSICOLOGIA

\title{
MODO DE VIDA E VIVÊNCIA DO MORTO NA TENDA ESPÍRITA DE UMBANDA PAI BENEDITO
}

Flávia Andréa Pasqualin 
Flávia Andréa Pasqualin

\section{MODO DE VIDA E VIVÊNCIA DO MORTO NA TENDA ESPÍRITA DE UMBANDA PAI BENEDITO}

Dissertação apresentada à Faculdade de Filosofia, Ciências e Letras de Ribeirão Preto - USP, como parte das exigências para a obtenção do título de Mestre em Ciências. Área: Psicologia. 
FICHA CATALOGRÁFICA

\section{Pasqualin, Flávia A.}

Modo de vida e vivência do morto na Tenda Espírita de Umbanda Pai Benedito. / Flávia Andréa Pasqualin; Orientador: José Francisco Miguel Henriques Bairrão.

Ribeirão Preto, 2009. 121 p.

Foto da capa: Dona Chiquinha

Foto da epígrafe: Joana

Dissertação, apresentada à Faculdade de Filosofia, Ciências e Letras de Ribeirão Preto / USP - Dep. De Psicologia e Educação.

1. Etnopsicologia Afro-brasileira. 2. Umbanda. 3. Psicologia da Religião 4. Psicologia da Cultura 5. Narrativa 
Nome: PASQUALIN, Flávia Andréa

Título: Modo de vida e vivência do morto na Tenda Espírita de Umbanda Pai Benedito

Dissertação apresentada à Faculdade de Filosofia Ciências e Letras de Ribeirão Preto - Universidade de São Paulo, departamento de Psicologia e Educação, para obtenção do título de Mestre em Psicologia.

Aprovado em:

Banca Examinadora:

Prof. Dr. Instituição:

Julgamento: Assinatura:

Prof. Dr. Instituição:

Julgamento: Assinatura:

Prof. Dr. Instituição:

Julgamento: Assinatura: 


\section{DEDICATÓRIA}

À minha mãe, pela dedicação e zelo com a neta, o que me permitiu ter tempo para a elaboração e escrita. Ao meu pai, pelo incentivo e apoio na execução desse trabalho.

À minha irmã, por ter inventado tantos passeios com a sobrinha.

À minha filha, que me trouxe tantas experiências e aprendizados durante esse trabalho.

À todo o terreiro de Pai Benedito, pela receptividade, respeito e carinho com que participaram da construção dessa pesquisa. Em especial, a D. Chiquinha por ter deixado um sólido trabalho na caridade, que hoje, mesmo depois de sua morte continua acolher a quem precisa.

A todos os membros e colaboradores do Laboratório de Etnopsicologia da FFCLRPUSP e, principalmente, ao professor Miguel Bairrão pela orientação. 


\section{AGRADECIMENTOS}

À amiga Fabiana, pelas palavras preciosas num momento tão decisivo dessa pesquisa.

À amiga Reuter, pela paciência e interesse em ouvir minhas histórias e descobertas.

À amiga Ana Carla, pelas "misteriosas" trocas de informações.

À colega Mariana, "companheira de esquerda", por ter tornado tantas idas e vindas à Jardinópolis, em momentos de reflexão e descontração.

A todos os membros da banca de defesa, pela colaboração na consecução deste trabalho e pela contribuição ao meu amadurecimento intelectual. 


\section{Aprender é apropriar-se da linguagem;}

É historiar-se, recordar o passado para despertar-se ao futuro;

é deixar-se surpreender pelo já conhecido.

Aprender a reconhecer-se, admitir-se...

Crer é criar. Arriscar-se a fazer dos sonhos,

textos visíveis e possíveis...

Alícia Fernandez, 2001 


\section{RESUMO}

PASQUALIN, F. A. Modo de vida e vivência do morto na Tenda Espírita de Umbanda Pai Benedito. 121 p. Dissertação (Mestrado) - Faculdade de Filosofia Ciências e Letras de Ribeirão Preto, Universidade de São Paulo, 2009.

Essa pesquisa trata-se do estudo de caso de um terreiro de umbanda, a Tenda Espírita de Umbanda Pai Benedito, situada na cidade de Jardinópolis-SP. Teve como objetivo geral apreender o modo de vida de uma comunidade afro-brasileira e específicos identificar especificidades e possibilidades de construção de significados abertas pelo recurso ao dispositivo cultural que afirma a sobrevida dos mortos e a sua participação na vida social e psicológica dos vivos, como também, conhecer concepções umbandistas a este respeito. O método adotado foi a participação da pesquisadora no cotidiano do grupo e o registro sistemático das narrativas que envolviam relatos deste tipo. Para efeito de análise deixou-se em suspenso quaisquer juízos a respeito da plausibilidade ou inverosimilhança da tese, uma vez que não se tratou de discutir a crença metafísico-religiosa subjacente, mas tão somente de observar e descrever o seu alcance na vida psíquica e na interação social. Sendo assim, admitido que o morto participa da vida social e psíquica do grupo, visou-se compreender como essa "presença" entre os vivos cria ou modula sentidos e possibilidades de vivências psíquicas, assim como regula as relações interpessoais. $O$ método adotado foi o etnográfico, que proporcionou uma "participação observante", com o objetivo de descrever a comunidade "por dentro" e a história oral, foi utilizada como um recurso a mais para ouvir os relatos orais. Para efeito de análise levaram-se em conta considerações teóricas a respeito da natureza do discurso narrativo, inspiradas em Lacan e Bakhtin, que propiciaram tratar "além das narrativas". Contudo, não se pretendeu esgotar a totalidade de possibilidades abertas por estes recursos. Conclui-se que o recurso ao "morto" como significante e interlocutor social possibilita grande riqueza e sutileza de recursos expressivos, capazes de fortalecer laços interpessoais e intergeracionais e de promover concomitantemente inclusão social e integração psíquica.

Palavras-chave: Etnopsicologia Afro-brasileira / Umbanda / Psicologia da Religião / Psicologia da Cultura / Narrativas 


\section{ABSTRACT}

PASQUALIN, F. A. Way of life and experience of dead in the Pai Benedito Spiritist Umbanda Tent. 121 p. Thesis (Masters) - University of São Paulo at Ribeirão Preto Faculty of Philosophy Sciences and Letters, 2009.

This research is a case of an umbanda worship place, the Pai Benedito Spiritist Umbanda Tent, located in the city of Jardinópolis, state of São Paulo. The study aimed, generally, to apprehend the way of life of an African-Brazilian community and specifically to identify specificities and possibilities of construction of meanings open by the resort to the cultural device that states the survival of the dead people and their participation in the social and psychological life of the people alive; to know the umbanda conceptions on this issue. The adopted method was researcher's participation in the daily life of the group and the systematic register of the narratives involving such reports. For the analysis, no judgment was done regarding the plausibility or unlikelihood of the thesis, since the implied metaphysical-religious belief was not discussed, the study only observed and described its reach on the psychic life and social interaction. Thus, assuming the dead people participate in the social and psychic life of the group, the study aimed to comprehend how this "presence" among alive people creates or modules meanings and possibilities of psychic experiences, as well as how it regulates interpersonal relationships. The ethnographic method was used, permitting an "observant participation" by the researcher, aiming to describe the community "from the inside". The oral history was used as an additional resort to listen to the oral reports. The theoretical consideration of the narrative discourse, inspired in Lacan and Bakhtin, was considered for the analysis, which enable to consider "beyond the narratives". Nevertheless, it was not aimed to drain all possibilities opened by these resorts. It is concluded that the resort of the "dead" as significant and social interlocutor permits abundant and subtle expressive resorts, responsible to strengthen interpersonal and intergenerational ties, and to promote, simultaneously, social inclusion and psychic integration.

Key words: Etnopsychology Afro-brazilian / Umbanda / Psychology of Religion / Psychology of Culture / Narrative 


\section{Sumário}

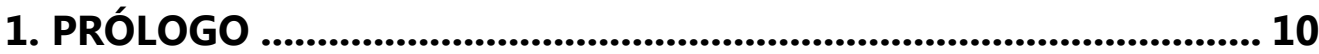

2. INTRODUÇÃO

3. CONSIDERAÇÕES TEÓRICAS .......................................................... 23

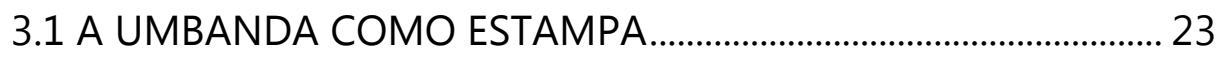

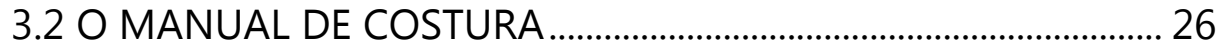

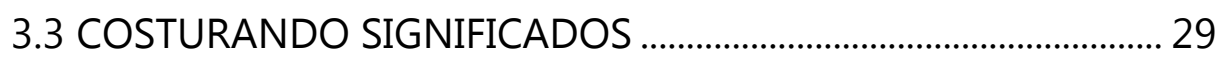

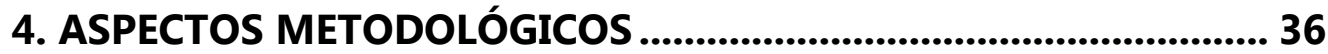

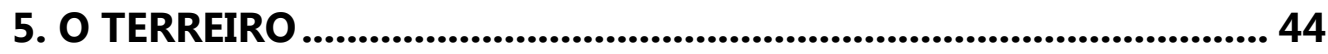

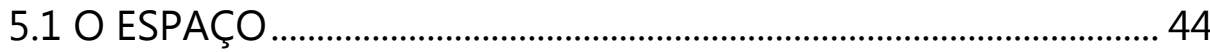

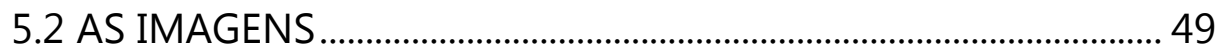

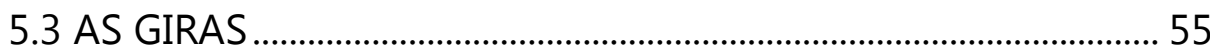

5.3.1 Giras no terreiro ..................................................................... 55

5.3.2 Giras fora do terreiro ............................................................. 71

5.3.3 Giras festivas............................................................................ 76

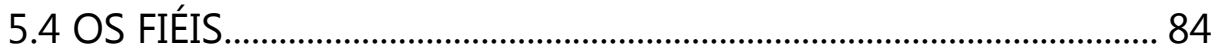

5.5 UTILIZAÇÃO DE PLANTAS................................................................ 86

5.6 D. CHIQUINHA, JOANA E A FORMAÇÃO DO TERREIRO .......... 91

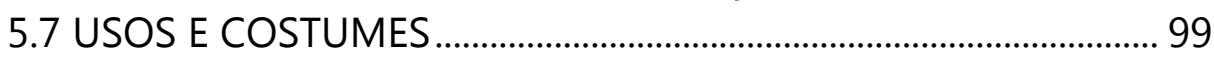

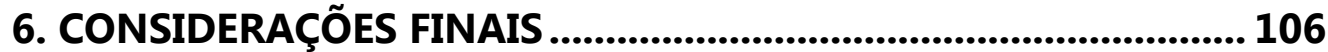

REFERENCIAS BIBLIOGRAFICAS ..............................................112

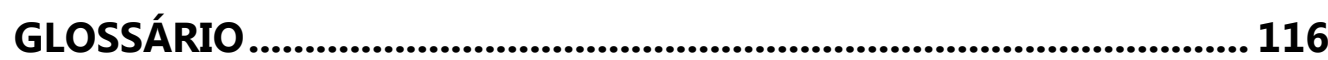

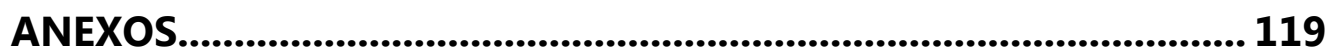

Anexo 1 - Termo de consentimento após informação

Anexo 2 - Normas para os médios do terreiro 


\section{PRÓLOGO}

Uma vez que descrevo o modo de vida no terreiro de Pai Benedito e conto histórias de vida pertinentes a essa casa, acredito ser relevante, ao iniciar, começar contar o meu (re)encontro com o terreiro escolhido para a realização dessa pesquisa.

Com efeito, disposta a adentrar o universo da umbanda, fez-se necessário, primeiramente, conhecer o objeto a ser estudado e para tal, eu deveria conhecer terreiros de umbanda. Em nosso laboratório de pesquisa os membros mais antigos apresentam os locais já freqüentados aos membros que estão chegando - no caso, eu era o membro novo - afim de que esses últimos possam se familiarizar com o local e com a linguagem utilizada pelos praticantes da umbanda, uma vez que trabalhamos com o método etnográfico. Dessa forma, naquele dia, dois colegas visitariam o terreiro de Joana (refiro-me à "Tenda Espírita de Umbanda Pai Benedito", nome oficial da casa), em Jardinópolis, e me convidaram para participar da ida ao local.

Devido às várias histórias que permeiam nossa sociedade sobre a umbanda, tais como: magia, feitiçaria, charlatanismo e assim vai..., lá fui eu, com as mãos trêmulas de medo e a imaginação em total atividade para a minha primeira visita a um terreiro. Entretanto, ao chegar, em poucos minutos, pude constatar toda a riqueza daquele local - não me refiro à riqueza material e sim à riqueza cultural de tudo o que estava ali e seus significados.

Outras visitas a novos terreiros aconteceram, mas já havia uma simpatia pelo primeiro local visitado. Quando ali retornei pela segunda vez, algumas imagens vieram a minha mente. Era como se eu já tivesse estado ali, embora com algumas imagens que me vinham à mente eram diferentes das que eu estava observando naquele momento. Como por exemplo, recordava-me de um chão vermelho e que, hoje, é verde. Esses pensamentos permaneceram comigo por mais algum tempo. 
Certo dia, ao comentar sobre minha pesquisa com uma tia-avó, simpatizante de "benzeções", leituras de mão, jogos de búzios e coisas do tipo, conto a ela sobre os terreiros visitados e pergunto se ela conhece o "terreiro de Joana", muito antigo em Jardinópolis, uma vez que, durante muitos anos, essa tia foi proprietária de um rancho às margens do rio Pardo, que fica na cidade mencionada. Minha tia, desconhecia o local, porém conheceu uma senhora, D. Chiquinha, benzedeira muito famosa daquela cidade (por sinal, já tinha ido benzer-se com ela várias vezes), e que havia morrido há pelo menos dez anos. Assim, interessada em conhecer o local de que eu havia falado, pede-me para levá-la.

Quando nós estávamos no terreiro de Joana, imediatamente, recordo-me, de uma única vez, em que ela havia me levado para ser benzida. Na ocasião, eu deveria ter cerca de quatro ou cinco anos. Aquela experiência havia me marcado porque o local era diferente de tudo o que, até aquela idade, eu estava acostumada a ver e, também, pelo pedido para que se retirasse os sapatos antes de adentrar o local, o que me causou uma enorme curiosidade e várias perguntas se fizeram na minha cabeça. Talvez algumas das quais eu venha, hoje, depois de tantos anos, tentar responder.

Numa terceira visita ao terreiro de Joana, ocorre-me um insight e, assim que termina a gira ${ }^{1}$, vou até ela e pergunto se naquele local havia tido, em alguma época, as características das quais me recordava. Por exemplo, o chão que hoje é verde, na minha memória aparecia como vermelho. Ela afirma que sim mas, naquele tempo, era sua mãe, D. Chiquinha, a mãe-de-santo da casa.

Pois bem, vinte e cinco anos depois, eu estava de volta ao primeiro terreiro em que havia pisado na minha vida, sem mesmo me dar conta, naquela época, de que ali era um terreiro de umbanda.

Depois disso, cada vez que minha tia retornava ao terreiro, levada por mim, eram horas ouvindo histórias sobre o tempo de D. Chiquinha, sobre o tempo de hoje,

\footnotetext{
${ }^{1}$ Para melhor compreensão do texto aos leitores não familiarizados com o vocabulário umbandista, a definição das palavras sinalizadas com esse asterisco " * " encontram-se no Glossário.
} 
sobre os filhos, os netos e, cada vez mais, eu fui me aproximando e me inteirando da história daquele terreiro tão antigo e tradicional na região, tendo o privilégio de ouvir várias facetas que talvez não chegassem aos ouvidos de um pesquisador.

Assim a vida, essa enorme colcha de retalhos, da qual só podemos ver sua beleza depois de finda, foi amarrando vários fragmentos e costurando cada história que havia sido começada. Contudo, num grande "ponto de estofo", pude compreender toda a trama.

Durante a graduação, inicio um estágio extra-curricular no CDP (Centro de Detenção Provisório de Ribeirão Preto) e, apaixonada pelo trabalho e pelas histórias que ouvia dos presidiários surge o desejo de pesquisar sobre esse universo tão inverso!

Ao procurar um orientador com o qual eu pudesse dar continuidade aos estudos lacanianos e trabalhar com as questões sobre marginalidade e exclusão social, chego a um grupo de pesquisa na área da psicologia social e, só depois, fico sabendo que pesquisam, especificamente, religiosidade afro-brasileira. Até então, apenas dois retalhos para mim: meu desejo de pesquisar algo sobre marginalidade e um grupo que estudava umbanda. O fio, talvez, Lacan?

Assim, alinhavando as histórias que eu trazia sobre minhas experiências na graduação, surge o convite, feito por meu orientador, para que eu ficasse no grupo para pesquisar exus.

Qual a relação entre exus e presidiários?

Esclareço ao leitor que, a umbanda divide suas entidades em dois campos, da direita e da esquerda.

"Assim estão do lado "direito" os orixás, sincretizados com os santos católicos, e que ocupam no panteão o posto de chefes de linhas e de falanges. São reverenciados, mas pouco ou nada participam do "trabalho*" da umbanda, isto é, da intervenção mágica no mundo dos homens para a solução de todos os seus problemas, que é o objetivo primeiro da umbanda enquanto religião ritual. Ainda, do lado do "bem", estão o caboclo (que representa a origem brasileira autêntica, $o$ antepassado indígena) 
e o preto-velho (símbolo da raiz africana e marca do passado escravista e de uma vida de sofrimentos e purgação de pecados). [...] De todas as classes de entidades da umbanda, que são muitas, certamente o preto-velho é o de maior reconhecimento público [...]. Ele é o sábio, paciente, tolerante e carinhoso. [...] Do panteão da direita também fazem parte os boiadeiros, os ciganos, os marinheiros. [...] 0 lado da esquerda é povoado pelos exus e pombagiras, basicamente. (PRANDI, R. 1996, págs. 141-146)"

Bairrão (2004a, p. 193-214) vai nos dizer sobre os exus e as pombas-gira, que

"Os exus representam liberdade e responsabilidade. Por isso associam-se a encruzilhadas. Também metaforizam a morte, numa acepção ética, como a possibilidade de escolhas contrárias à orientação do espírito. Mas é pouco referi-los nestes termos, entre o óbvio e o moral. Mais profundamente (e profundidade é com eles mesmos), não se deve esquecer que, em muitas tradições religiosas, a verdadeira morte é a vida corporal e o corpo é espiritualmente significado como um túmulo (tumbas e catacumbas, são aliás uma das suas especialidades...). Na umbanda e congêneres, chama-se de exu uma função espiritual associada à sombra que a corporeidade humana projeta na luz. Inequivocamente esta classe espiritual se associa à vida corporal e aos interesses individuais. Vincula-se ao eu de fato existente e talvez por isso seja considerada tão próxima do humano. Sempre que há separação entre eu e os outros, eu e o resto (a condição humana "normal"), pode haver choques de interesses e o "bem" de uns ser "mau" para outros. [...] As pombas gira apresentam o telúrico como receptivo e aprazível, em forma humana. Associadas aos fascínios do corpo, expressam espiritualmente a sexualidade e a sedução, a fertilidade da terra e os prazeres sensoriais. São muito amigas e solidárias com as vítimas de maus tratos provocados pelo temor ao prazer e à lubricidade. Não é raro que se espelhem em biografias humanas que contam com o recurso a talentos e meios eróticos para sobreviver (amantes, prostitutas, etc.). Provavelmente uma versão brasileira contemporânea de ritos de fertilidade e do culto a deusas mães, a sua associação à voluptuosidade da vida não desperta simpatia por parte dos que repudiam o corpo como um horizonte de experiência do sagrado, muitos dos quais, privados dos seus favores, intimidados pelo esplendor da sua nudez, intentam recobri-la com conotações de malignidade." 
O culto das entidades de esquerda já foi tratado como religião separada, a quimbanda, mas podemos ver exus e pombas-gira na umbanda.

De acordo com Trindade (1985), os exus introduzem a possibilidade de mudanças, eles são a encarnação do desafio, da vontade, da irreverência. Permitem aos homens a possibilidade de autodeterminação, de quebra das interdições sociais que limitam a sua liberdade - desordem. Exu também é um símbolo masculino de sexualidade e fertilidade. Sua imagem mais comum na umbanda é a do diabo católico. Dizem ser o exu a divindade mais próxima ao homem.

Segundo Amaral (2000), na África, ele é compreendido como um deus do movimento. Para Sikiru Salami, sacerdote nigeriano, (1999, p. 103), exu é "temido e evitado não por ser malévolo e sim por ser extraordinariamente poderoso".

Com efeito, exu freqüentemente é relacionado ao marginal em vários sentidos, pois no panteão umbandista pode incumbir-se de dar voz ao lado obscuro do ser humano.

Dessa forma, as entidades que atendem por exu, que a princípio "me levaram" à umbanda, associam-se, comumente, ao socialmente "recalcado". Muito daquilo que é banido pela sociedade está figurado no exu; até mesmo o local em que ele se encontra no terreiro é escondido, o que podemos equiparar ao inconsciente. $\mathrm{O}$ exu se presta ao papel de simbolizar tudo o que é marginalizado por essa sociedade, embora não se pretenda que ele a isso se reduza.

$\mathrm{Na}$ página seguinte, encontra-se a imagem de um exu, que pertence a tronqueira* do terreiro. 


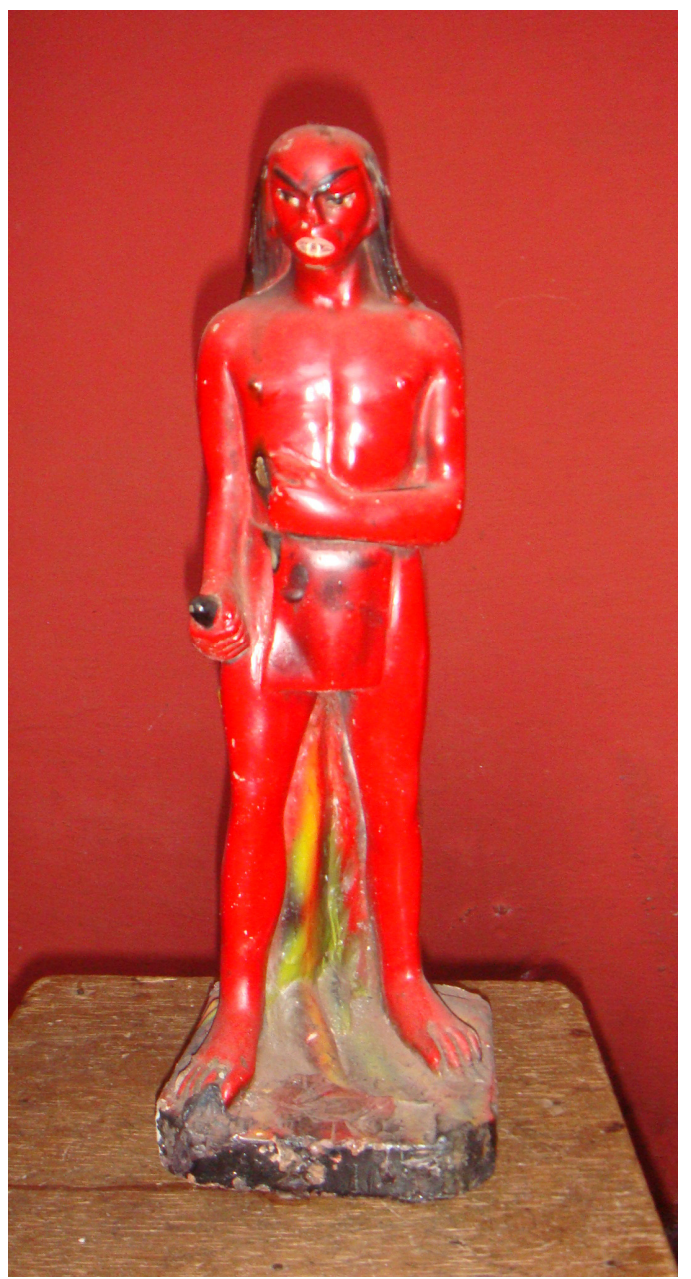

Figura 1: Exu.

Partindo do princípio de que "o bom filho à casa torna", a familiaridade com a casa - no caso, o terreiro - me possibilitou conquistar espaços necessários e imprescindíveis para o estudo, não apenas do exu, mas também das narrativas biográficas e das interações psíquicas e sociais entre freqüentadores do terreiro, atuais (vivos) e antigos (mortos).

Assim, como Ariadne e seu fio, adentrei um labirinto de encruzilhadas. Caminhos sinuosos que me fizeram retornar ao primeiro e único terreiro que havia pisado até então.

O exu recolheu-se, ou melhor, mostrou-se, a princípio, pelo "sem sentido", e no seu lugar, outra entidade apareceu, "tomando a frente" do trabalho. 
Na minha primeira ida, com o grupo de pesquisa, ao terreiro de Joana, ao ser benzida por Pai Benedito (espírito de um preto-velho recebido por Joana), ele comenta sobre uma cigana que me acompanha.

A fala de Pai Benedito surge da seguinte forma: ele me pergunta sobre umas coceiras que tenho (esclareço de antemão, ao leitor, que isso nunca havia sido comentado com ninguém e que, essa queixa já havia me levado a percorrer vários médicos). Assim, diz ele, na sua voz humilde: "sabe fia, essas coceiras que ocê têm? Que ôce vai nexis homi de branco? Que acorda de noite?! Essas coisas que ocê sente?! É a cigana que tá do seu lado, é ela que te fala as coisas! Exas coisa é tudu sua mediunidade. É que ocê é média." Dessa forma, surge uma interpretação do campo sobre mim: a mediunidade e a necessidade de desenvolvê-la, e com o tempo, surgem os convites para as festas de ciganos (também fechadas ao público como as de exus).

O leitor deve estar se perguntando porque falo dessa cigana, agora?!

Explico: durante a escrita dessa dissertação houve vários percalços, alguns a mais do que o esperado em qualquer estudo, acredito eu. Durante a pesquisa, engravido e peço uma licença. Depois, ao retornar e iniciar a parte escrita do trabalho, vários acontecimentos surgem na minha família e não consigo retornar aos estudos com a dedicação necessária. Fico indecisa e, por várias vezes, acho melhor desistir da pesquisa. Fico trancada nas minhas próprias indecisões e, cada vez que sento à frente do computador, algo acontece para atrapalhar. Encruzilhadas do labirinto? Poderíamos tecer várias interpretações psicanalíticas, mas como meu desejo é conhecer o universo umbandista, nada melhor que levar esses acontecimentos para que os próprios umbandistas façam suas interpretações, e eu dessa forma, possa conhecer sua lógica.

Comento as minhas dúvidas e dificuldades com mãe de santo e peço a sua opinião sobre o assunto. Joana dá o seu parecer, mas prefere que eu me consulte com o Pai Benedito para que ele veja o que está acontecendo. Durante a consulta, Pai Benedito conversa com "minha cigana" e me diz que é ela quem não me deixa 
escrever o trabalho, pois ela é meu guia de cabeça (entidade espiritual que me conduz) e não posso começar a escrever sobre outra entidade, no caso os exus.

Vale dizer, que tentei, mais uma vez escrever essa dissertação sem me referir à tal cigana e, por problemas técnicos, perdi meu trabalho, precisando recomeçar novamente. Todavia, cá estou eu, reverenciando o Povo do Oriente e pedindo sua permissão para abrir meu "trabalho". Nesse momento, ocorre-me que a tia que me levou até o centro da Joana, durante muitos anos, recebia seu guia* espiritual, que era Ramsés (entidade espiritual da linha do Oriente, como a cigana).

Elaborando a questão da entrada dos ciganos no trabalho, começo a pensar na sua relação com exu e vem-me à mente haver nos cultos afro-brasileiros uma relação de exu com Ifá, oráculo da adivinhação, assim como a cigana que prevê o futuro.

Podemos pensar que, "apresentada" por "minha cigana", obtive a permissão para pesquisar o povo da esquerda, o que me foi revelado através de um sonho muito esclarecedor e interpretado pela própria mãe de santo. Nele, eu estava no terreiro, durante uma festa belíssima onde havia muita fartura de comida e belos trajes e, de repente, Joana me pega pela mão e me faz atravessar um imenso jardim, deixando a multidão para trás. Assim, ela se vira para mim e diz que eu tinha permissão para pisar naquela área onde havia várias imagens de exus. Essas imagens eram estátuas maiores que o tamanho de uma pessoa e inteiramente branca. Mostrame uma estátua muito grande de um exu e, quando ele me vê, sorri. Ao contar o sonho para Joana ela logo diz que é festa de cigano, pois são eles que gostam de luxo; e as descrições que fiz da imagem do exu visto no sonho, ela refere-se ao seu exu, um dos guias do terreiro... "nossa tô arrupiada, esse é o meu exu é o [...]. Se sorriu é porque
está te ajudando."

(Depoimento Joana - 03/02/2006) 
Com efeito, ao freqüentar as giras de várias linhas de entidades, com assiduidade, passo a fazer minhas anotações de campo sentada dentro do conga*, e sempre que surge uma oportunidade, vou fazer as vezes do cambone*. Ao lado da mãe de santo, num lugar privilegiado, obtenho a permissão para transitar por vários lugares dentro do terreiro, como a tronqueira, lugar estritamente reservado aos médiuns da casa.

Contudo, como cambone, a pedido da mãe de santo, passo a acender velas para meu anjo da guarda, antes de iniciar a gira e, de tempos em tempos, para a minha "escora*", para a minha cigana e para Pai Benedito.

Os demais médiuns da casa também realizam esse trabalho para a escora todos os meses. A vela para Pai Benedito é porque ele é o chefe espiritual da casa, para o exu é para que ele tome conta da nossa vida afastando-nos do mal e, para a cigana porque ela seria meu guia de cabeça.

Assim, com a permissão para ir em frente, convido o leitor a seguir o fio...

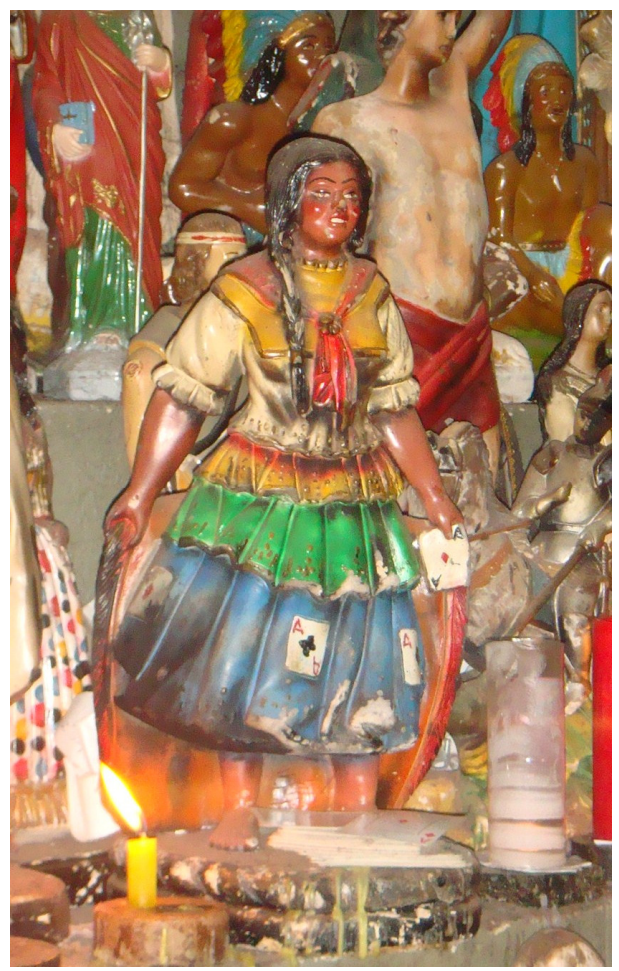

Figura 2: Imagem da cigana Maria. 


\section{INTRODUÇÃO}

"O que fazer, se não me reconheço? Não sou cristão, judeu ou muçulmano (...). O meu lugar é sempre o não lugar, não sou do corpo, da alma, sou do Amado.

(Rûmî)

Ao aproveitar a belíssima poesia-reflexiva de Rumi (místico persa, nascido em 1207), que me chega às mãos quando estou finalizando minha dissertação, percebo que ela faz parte do início desse trabalho e, agora, consigo ver que, enquanto tecia essas páginas, a minha própria história estava sendo fiada também, juntamente com a história do terreiro de umbanda que aqui é narrada.

Toda pesquisa surge de uma questão, mas sabemos que ao atravessar as palavras, descobrimos sentidos que estavam muito além de nossas ilusões.

Permeada por histórias que trazia desde criança, busco um caminho para continuar entre as narrativas religiosas. Encontro um tema: estudos sobre religiões afro-brasileiras.

E assim, disposta a percorrer os subterrâneos das histórias que cruzaram meu caminho, inicio meu trajeto com o estudo da umbanda, uma vez que esta religião possui um universo simbólico associado ao imaginário popular brasileiro, na qual podemos encontrar modelos de brasileiros menos valorizados, dentre os quais foram os primeiros a se enunciarem nessa trama através dos presidiários (já descrito no prólogo) para que esse(a) novelo(a) pudesse se desenrolar.

Contudo, ao encontrar acolhida para minhas histórias, inicio um estudo de caso da Tenda Espírita de Umbanda Pai Benedito, uma antiga e tradicional casa de umbanda. A escolha desse local, vem de acordo com a afirmação de Lutz (1988), a qual afirma que os estudos em etnopsicologia servem para apreender o modo como 
as pessoas de um determinado meio cultural vivem, se relacionam, e dão sentido às suas diversas vivências.

O seu estudo torna-se importante para a psicologia na medida em que o conhecimento à intervenção dos mortos junto aos vivos certamente permite tocar uma série de efeitos sociais e psicológicos que são ainda muito mal conhecidos.

Sendo assim, o estudo de caso do referido terreiro teve como objetivo apreender o modo de vida dessa comunidade e resgatar concepções umbandistas sobre o significado da participação do morto no contexto psicológico individual e comunitário, por meio de minha participação no cotidiano do grupo.

Uma vez que o morto participa da vida social e psíquica do grupo, visei compreender como essa "presença" entre os vivos cria ou modula sentidos e possibilidades de vivências psíquicas, assim como regula as relações interpessoais. Ou seja, busquei clarificar alguns tipos de efeito que esses entrelaçamentos podem produzir do ponto de vista psicológico.

Ainda que do ponto de vista etnográfico ou mesmo estritamente religioso, os cultos afro-brasileiros e o seu recurso à possessão, tenham sido bastante estudados, do ponto de vista psicológico são pouco conhecidas as possibilidades de expressão e os recursos psíquicos possibilitados por este dispositivo cultural, pelo que o estudo pode contribuir para a sistematização de uma etnopsicologia afro-brasileira.

Não se pretende esgotar a totalidade de possibilidades abertas por este recurso, mas tão somente arrolar aquelas que se mostraram depreensíveis pelo modo como a comunidade do terreiro incluiu e significou minha presença, como conta as suas histórias e pratica a sua religião.

Uma vez que,

“[...] a Umbanda tem como característica ser uma religião de inclusão social, na qual as histórias dos setores populares são aceitas, compreendidas e reelaboradas, de forma a dar sentido à vivência social de cada um, ela constitui-se uma ocasião ímpar para promover formas de diálogo entre a psicologia acadêmica e 
o saber "psicológico" popular. A umbanda dá voz ao recalcado social e questiona a estaticidade da tradição, consagrando o humano e pondo no seu panteão a totalidade das suas sutilezas, agradáveis ou não, o que a torna uma excelente oportunidade para refletir formas sociais de cognição e alternativas de resistência étnica e cultural, uma vez que seu culto conjuga saber popular e uma ética crítica, implícita nas suas "magias" (BAIRRÃO, 2002, p. 65)".

Através das histórias contadas e do enunciado pelo vasto repertório de recursos significativos intrínseco à pratica umbandista, procurei verificar as especificidades existentes nessas narrativas que, juntas, dão voz a processos etnopsicológicos pertinentes ao grupo estudado.

É importante dizer que, o interesse pelas narrativas no espaço onde elas são produzidas e transmitidas, no caso um terreiro de umbanda, exigiu de mim enquanto pesquisadora, uma participação na vida cotidiana do lugar, criando um vínculo forte, marcado pela confiança e pela informalidade, através da observação participante, ou seja, adotei o método etnográfico por ser o mais coerente ao trabalho que se pretendia desenvolver.

Percorrendo, rapidamente, o conceito de etnografia, encontramos definições que colocam a etnografia como a ciência que descreve os usos e costumes dos povos, de uma determinada cultura, valendo-se do registro de fatos observados durante o trabalho de campo. Seria puramente descritiva mas, durante sua prática ao longo dos anos, com a aproximação do investigador ao seu objeto de estudo, viu-se que, nas entrelinhas das descrições realizadas em campo sobre as comunidades observadas, havia também o etnógrafo.

Para que essas histórias pudessem formar uma "colcha de significados" e dar sentido ao meu trabalho, busquei apoio em alguns procedimentos da História Oral, como sendo um recurso a mais para estruturar tudo o que chegava aos meus ouvidos. 
A História Oral utilizada como um meio moderno de apreensão de fontes orais pode se apresentar em três eixos: história oral de vida, história oral temática e tradição oral. Contudo, nesse trabalho, inspirei-me na História Oral na modalidade temática, uma vez que os depoimentos foram colhidos tendo como base o tema da incidência do morto no modo de vida da comunidade.

No caso deste estudo, o recurso a alguns instrumentos da História Oral aparece não numa perspectiva de transformar as narrativas em documentos históricos, mas com a intenção de transformar em texto algumas narrativas biográficas, no intuito de promover um diálogo entre o popular e o acadêmico, para que a fala de uma minoria possa ser enunciada, à medida em que o "verbo se faz carne" e alimenta os desejantes da palavra escrita.

Para ouvir além das palavras que surgiam nas narrações, fez-se de grande valia o conhecimento sobre o discurso narrativo - lócus privilegiado para a instalação da subjetividade (TFOUNI, 1995).

Com efeito, a fim de esclarecer melhor o leitor acerca desta proposta de pesquisa, serão apresentadas, a seguir, algumas considerações teóricas que são as fundamentações do estudo e, posteriormente, serão apresentados os procedimentos adotados para a observação participante da vida religiosa e comunitária e para o registro das suas histórias, assim como elas próprias e algumas reflexões finais. 


\section{CONSIDERAÇÕES TEÓRICAS}

\section{1 - A UMBANDA COMO ESTAMPA}

"Lá no terreiro, tudo era alegria Negro batia na zabumba e o boi gemia."

(Geraldo Filme)

Neste capítulo, começo propondo ao leitor que conheça um pouco sobre a religião a que venho me referindo - a umbanda. A qual surge nessa colcha de retalhos, como uma fina estampa, que através de suas figuras e coloridos anuncia o universo com o qual trabalhei.

Assim, busco algumas palavras que tentam defini-la, e como já disse Maggie (2001, p. 111) "na umbanda, cada terreiro é uma igreja, constituída por seus médiuns e sua clientela" e acrescento; uma igreja sem papado, pois cada terreiro age à sua maneira, independentemente uns dos outros.

A umbanda é uma religião de sincretismos. Nela encontramos elementos do candomblé, do catolicismo e do espiritismo convivendo em perfeita harmonia, e ultimamente, também podemos encontrar em alguns terreiros influências new age.

Prandi (2006) vai nos dizer que menos de um por cento dos brasileiros dizem praticar alguma religião afro-brasileira. No entanto a visibilidade da umbanda e do candomblé é muito grande e muitos símbolos da identidade do Brasil, assim como práticas culturais importantes, são originários dessas religiões. Embora muitos digam não a praticar, em meus estudos pude atestar uma grande quantidade de freqüentadores que dizem pertencer a outras religiões, mas vão buscar alívio para suas tensões e/ou conselhos para suas dificuldades com os guias espirituais da umbanda. 
A umbanda é geralmente compreendida como a primeira religião nascida em solo brasileiro. Apesar de algumas vertentes suporem uma origem indiana, a verdade é que muitos dos seus usos e termos, inclusive a própria palavra "umbanda", têm claras raízes africanas (bantas). Sobre esse tronco enxerta-se a sua brasilidade e o seu panteão comporta imagens de tipos populares brasileiros, como o caboclo, o baiano e o preto-velho. Tal como afirmam Brumana e Martínez (1991), a umbanda não fala da história do universo, do homem, mas da vida cotidiana e das aflições que as pessoas têm nela.

Segundo Birman (1985) na umbanda ocorre uma inversão simbólica em que os estruturalmente inseridos em posições inferiores na sociedade são detentores de um poder mágico particular.

\footnotetext{
"Ao mesmo tempo em que a umbanda acata os valores sociais dominantes em que determinados grupos sociais são vistos como "inferiores" e "primitivos", ela retira desse estigma a sua forma" (id., ibidem., p.46).
}

Acrescente-se que a umbanda é uma religião de possessão e a tem como um fenômeno central em seus cultos.

Na umbanda, "[...] a possessão valoriza a participação individual nos rituais, pois é um fenômeno no qual se pode ver, claramente, a intercessão do coletivo com o individual (MAGGIE, 2001, p. 83)." E a autora acrescenta que

“[...] a possessão é um fenômeno coletivo, pois é um processo socialmente aceito, no qual as entidades que incorporam no médium fazem parte da mitologia e do sistema de apresentações do grupo. Mas ela é, ao mesmo tempo, a individualização desse coletivo, pois cada médium personifica uma ou várias dessas entidades, dando-Ihes uma interpretação pessoal (id., ibidem., p.84)." 
O imaginário umbandista integra o universo popular. Verifica-se que é tradição na Umbanda incluir experiências sociais traumáticas, estabelecendo orientações quanto ao tratamento de seus reflexos e elevando-as a símbolos religiosos aclimatados ao contexto brasileiro, os quais propiciam relações de identificação e de participação entre contemporâneos e matrizes históricas (BAIRRÃO, 2004b, p. 2).

De acordo com Negrão (1996), a Umbanda possui um universo simbólico claramente delineado e associado à criatividade do imaginário popular brasileiro. Pode-se ver nas tendas e terreiros uma produção e reprodução do sagrado na forma de modelos da condição do brasileiro subalterno ou de outras condições sociais, transmutados em deuses mediante inversão simbólica.

Bairrão e Leme $(2003$, p.6) vão dizer que há na umbanda uma prática religiosa que estrutura vínculos entre a vida terrena e o "mundo espiritual", como também organiza e reflete relações sociais e as condições de existência de seus praticantes, tornando-se extremamente importante nas suas vidas e sendo um fator de preservação cultural e social destas comunidades, compondo um vasto universo simbólico e ritual profundamente enraizado em seus integrantes, na forma de uma síntese original de elementos culturais de diferentes proveniências.

Na umbanda há uma ética de inclusão, que aceita a história de cada um, demonstrando uma maior flexibilidade frente às diferenças, pois cabe apenas compreender, e assim reformular e dar sentido as experiências vividas pelos seres humanos.

Dessa forma, ouvir as narrativas de uma mãe-de-santo nos informa sobre vivências e memórias psicossociais profundas relacionadas às figuras marginalizadas, bem como ás interpretações das suas razões e prescrições quanto aos remédios ético-político-religiosos que poderiam sanar as mal-ditas mazelas que afligem o corpo social brasileiro (BAIRRÃO, 2004).

Para que a escuta pudesse me conduzir a ouvir não só com os ouvidos, mas com todos os sentidos, uma vez que, "a umbanda é uma questão de gosto e os seus sentidos mais se provam do que se explicam" (BAIRRÃO, 2007, p.184), foi necessário 
valer-me de um "guia" e dessa forma, "incorporei" em meu trabalho o método etnográfico, o qual abordarei no próximo item, como sendo o fio condutor.

\section{2 - O MANUAL DE COSTURA}

Obedecendo ao manual de costura sobre como se fazer uma colcha de retalhos, no qual recomenda costurar pedacinhos de pano aleatoriamente, percebo que a escolha de cada pequeno quadradinho de tecido não foi feita ao acaso, pois em cada um havia um pouco de mim mesma.

Assim, adentrando a questão sobre o método etnográfico, o qual conduziu minha experiência em campo, acredito ser relevante começar esse capítulo pensando com o leitor sobre a situação em que a própria história é contada. Qual o contexto em que ela se apresenta? Quem conta? Onde? Quando? Para quem conta?

Qual a participação do pesquisador nesse (con)texto?

O método etnográfico, hoje de largo emprego nas ciências humanas, foi originalmente desenvolvido e tem sido refinado principalmente no âmbito da antropologia. Entende-se que

“[...] a pesquisa etnográfica propõe-se a descrever e a interpretar ou explicar o que as pessoas fazem em um determinado ambiente, os resultados de suas interações, e o seu entendimento do que estão fazendo. [...] Assim, a etnografia descreve a cultura de um grupo de pessoas, interessada no ponto de vista dos sujeitos (WIELEWICKI, 2001, p. 27-28)."

James Clifford (1998) em A experiência etnográfica explica que a escrita etnográfica não deve ser construída como uma afirmação de autoridade, assim como 
fez Malinowski em Argonautas do Pacífico Ocidental. Embora a observação fosse participante, para que as experiências pudessem ser compartilhadas entre pesquisador e grupo estudado, elas eram vivenciadas através da dedução, onde apesar de haver subjetividade, não havia intersubjetividade ou diálogo.

O etnógrafo, então, teria a capacidade de explicar a complexidade de um mundo o qual apenas observou?

Clifford (id.) também opina criticamente sobre a interpretação de uma realidade tal como a propõe Geertz. Segundo ele, este procurou ver a cultura como um texto, uma tessitura de significados elaborados socialmente pelos homens e acabou transformando a etnografia em interpretação das culturas.

Dessa forma, Clifford vai defender o reconhecimento e a admissão da presença concomitante de várias vozes no texto etnográfico. Para ele, de acordo com Bakhtin, toda linguagem é uma concepção heteróglota do mundo (id.). Defende, então, uma polifonia etnográfica, propondo que a escrita represente o etnógrafo e o nativo com vozes e discursos diferentes, as quais formarão novas vozes.

Em acordo com Crapanzano (1986), vejo que não há possibildades do pesquisador manter-se invisivel em seus textos. No entanto, de certa forma ele deverá dar voz ao grupo pesquisado e desaparecer no decorrer da escrita, para que a cultura pesquisada ganhe voz. Ele vai equiparar o etnográfo a Hermes, o qual "tiene la misión de clarificar lo obscuro, de trocar en familiar lo extraño, de interpretar lo que en apariencia no tiene sentido [...] (CRAPANZANO, ibidem, p.91)", mas sempre fazendo-se valer da função dialógica para que o outro possa emergir.

É conferindo ao outro o lugar de sujeito, que ele poderá reconhecer-se em suas falas e (re)significar suas vivências mais profundas.

Dessa forma, pensando na interação com o sujeito depoente busquei apoio em técnicas da História Oral, uma vez que na condição de pesquisadora também atuei como escriba daquela comunidade, cabendo a mim o papel importante de constituir e preservar os acervos orais que me chegaram. 
Thompson (1992, p.42), sobre a História Oral, vai dizer que "ela trata de vidas individuais - e todas as vidas são interessantes".

O trabalho de dar voz ao silêncio do pobre, do negro, dos excluídos da escola possibilita a emergência do subjacente, do subjetivo, do oculto, do obscuro que também fizeram história e, portanto, são legítimos e merecem vir à tona, como já disse Caiado (2006).

Os fatos relatados de uma vida, de uma memória individual, trazem o germe de uma memória social (id., ibidem).

Para Bom Meihy (2001) a grande força da história é que ela pode recuperar a memória de segmentos da sociedade que de outra forma se perderiam.

Permitir ao outro que ele construa um discurso ou uma narrativa é ocupar um lugar de quem se interessa por ele - o depoente - surgindo assim, laços de amizade. Nessa interação, pesquisador e pesquisado participam da construção de significados, uma vez que as palavras trazem sentidos marcados na história de cada um. Por ser polissêmica e dialógica, a palavra traz marcas culturais, sociais e históricas (BARBOSA, 2001, p.1).

Segundo essa autora, baseada em Bakhtin, o contexto histórico transforma a palavra fria do dicionário em fios dialógicos vivos que refletem e refratam a realidade que a produziu. Pois, por ser geradora de sentido, acaba sendo controlada e selecionada por seus interlocutores através de mecanismos sociais. E assim, a palavra vai se revestindo de sentidos, tons e valores e acaba sendo prenhe de significados (id., ibidem.).

\footnotetext{
"Em síntese, os significados ultrapassam a unidade semântica da palavra e encontram-se no drama da vida revelado na narrativa" (CAIADO, 2006. p. 51).
}

Para Orlandi (2008, p. 295), não há transparência na linguagem, ela vai dizer que a escuta discursiva envolve sujeito, linguagem e história. 
"Sendo assim, mesmo que a pesquisa etnográfica lance mão de diferentes fontes e de instrumentos para coletar seus dados e analisar as informações obtidas [...], as diversas vozes que constituem os discursos do pesquisador e dos sujeitos estarão sempre presentes, relacionando-se e criando novas vozes, nos moldes da heteroglossia bakhtiniana." (WIELEWICKI, 2001)

Tais observações são importantes quando queremos conhecer as ações humanas, já que sujeitos e sentidos se constituem ao mesmo tempo (Id. Ibidem). Disse Lacan que o sujeito é o que emerge entre os significantes.

Logo, foi de acordo com Clifford e Crapanzano que procurei caminhar, na intenção de encontrar um meio em que fosse possível trazer o ponto de vista dessa comunidade umbandista para o texto acadêmico.

\section{3 - COSTURANDO SIGNIFICADOS}

"Chega mais perto e contempla as palavras

Cada uma

Tem mil faces sob a face neutra"

(Carlos Drummond de Andrade)

Saber ouvir histórias é tão importante quanto saber contá-las.

Sherazade não teria permanecido viva, apesar de exímia contadora de histórias, se Sharima - o sultão - não (ou)visse além das palavras.

Assim, convido o leitor a desfiar as questões da narrativa, essa que entrelaça todos os tecidos da trama - o passado, o presente e o futuro. 
Desde os primórdios da humanidade podemos encontrar formas de expressões humanas que nos chegam, até os dias atuais, para contar algum acontecimento ou o desejo de acontecimento, e a narrativa é uma delas.

"Inumeráveis são as narrativas do mundo" (BARTHES, 1971, p. 19). A narrativa pode ser sustentada pela linguagem articulada, oral ou escrita, pela imagem, pelo gesto ou pela mistura ordenada de todas estas substâncias; está presente no mito, na lenda, na fábula, no conto, na novela, na epopéia, na história, na tragédia, no drama, na comédia, na pantomima, na pintura, no cinema, na conversação (id., ibid.).

Sobre o interesse do estudo da narrativa, Brockmeier e Harré (2003, p 526), citam vários autores e concluem que ela:

“[...] constitui um parâmetro lingüístico, psicológico, cultural e filosófico fundamental para nossa tentativa de explicar a natureza e as condições de nossa existência [...] é sobretudo através da narrativa que compreendemos os textos e contextos mais amplos, diferenciados e mais complexos de nossa experiência. [...] organizamos nossas memórias, intenções, estórias de vida e os ideais de nosso self, ou nossas "identidades pessoais", em padrões narrativos."

Dessa forma, acaba sendo através da narrativa que os seres humanos dão contorno as suas vivências, organizando-as de tal maneira que não há um compromisso com a realidade tangível, mas sim com a verdade de cada um. $\mathrm{E}$, nesse processo de dar significado as vivências pessoais é que se (re)cria a própria vida a ser vivida.

Segundo Ricoeur (1978, p.16),

“Contando histórias, os homens articulam sua experiência do tempo, orientam-se no caos das modalidades potenciais de desenvolvimento*, marcam com enredo e desenlaces o curso muito complicado das ações reais dos homens. Deste modo, o homem narrador torna inteligível para si mesmo a inconstância das coisas humanas[...]. 
Nesta pesquisa, entende-se que ao dar escuta àquele que narra, seja ele um "espírito" ou não, mas valendo-se desses "lugares" onde é produzida a narrativa, estaremos colhendo histórias de vivências que embora situadas de uma determinada singularidade subjetiva comportam sentidos que a ultrapassam. O depoente é também o "médio" de enunciados reveladores de memórias e verdades psicossociais mais ou menos cifradas.

Isto porque se entende o sujeito depoente, não apenas como aquele que fala sobre a umbanda, mas também que é a cultura umbandista, como fenômeno social, que nos fala através dele, posto que os significantes circulam socialmente, estabelecendo laços entre uma grande quantidade de pessoas (BAIRRÃO, 2002), não se atendo apenas a uma pessoa.

Com efeito, entende-se que os significantes estão presentes no contexto social, histórico, nas memórias, na fala, no não-dito, não sendo restritos ao psiquismo nem a indivíduos.

De acordo com Brockmeier e Harré (2003), baseados no que Bakhtin chamou de "princípio dialógico", vamos ver que cada palavra é polifônica, ou seja, seu significado é determinado por incontáveis contextos em que foi previamente utilizada, carregando consigo os traços de todos os sujeitos, possíveis e reais, que já empregaram tal palavra.

No entanto, Brockmeier e Harré (id. p. 529) alertam que as histórias devem ser ouvidas como articulações de narrativas particulares, a partir de pontos de vista particulares e localizadas em vozes particulares.

Pois, embora na narrativa haja um distanciamento aparente entre sujeito (quem narra) e objeto (sobre o que se fala), este objeto pressupõe logicamente um sujeito, o qual é apagado, mas ainda está lá, entre os significantes. O sujeito se reconhece no objeto e vice-versa. Dessa forma, tudo o que narramos traz a marca de nossa subjetividade (CARREIRA, 2002).

Baseados em estudos anteriores do próprio Harré e de Van Langenhove, Brockmeier e Harré (2003, p.529) nos dizem que: 
“[...] as narrações não podem ser consideradas como uma invenção pessoal ou individual, como afirmam os subjetivistas, nem tampouco simplesmente representam a descrição objetiva das coisas tal como ocorreram, como querem nos convencer os positivistas. As estórias são contadas a partir de proposições, ou seja, elas "acontecem" segundo ordens morais locais, nas quais os direitos e deveres das pessoas como falantes influenciam a localização da voz autoral primária."

Mesmo ouvindo as histórias como narrativas particulares, como é o caso deste trabalho, ao ouvir as narrativas da mãe-de-santo Joana precisamos estar atentos ao contexto em que elas ocorrem, principalmente, por se tratar de narrativas religiosas, sobretudo num culto de possessão, o que por si só literalmente já traz implícito uma fala habitada pelo outro: um dos desafios de se dar ouvidos a narrativas religiosas está na necessidade de se descriminar a autoria desses enunciados, uma vez que, tal como é o caso da possessão nem sempre o agente da enunciação é concebido como sendo o sujeito da enunciação (KEANE, 1997).

De acordo com Keane (id.), as formas narrativas tomadas pelo ritual religioso vão refletir as associações feitas pelos participantes sobre o agente da narrativa ou sobre o que está sendo requerido na comunicação. Em alguns casos, em religiões de possessão, quanto mais incompreensível for a fala, maior credibilidade se dará a comunicação por se entender que se trata da presença de um espírito. Sendo assim, os ouvintes podem construir as intenções do falante.

O que também ocorre, na possessão, é a manifestação de uma variedade de falantes que aparecem numa única pessoa, no caso o médio.

A fala muitas vezes não é suficiente para determinar o que está ocorrendo em uma cena de possessão (GOODMAN, 1972; WHYTE, 1990 apud KEANE, 1997), o que vem reforçar nossa proposta em levarmos em consideração tanto o texto que está sendo desenvolvido como o contexto em que ele está inserido.

Através de minha vivência no terreiro, pude atestar claramente como a fala, realmente, não pode ser o único dado para compreendermos uma cena de 
possessão. Por exemplo, sempre que Joana recebe Pai Benedito, a vela que acende ao lado de seu banquinho é branca, cor essa que representa os pretos-velhos. No entanto, várias vezes presenciei que a vela acesa não era branca e sim amarela. Quando pergunto o por quê daquela cor:

“Joana: Porque quando a vela é amarela, não é o Pai Benedito, é o meu baiano que está incorporado.

Pesquisadora: Nossa, não dá pra perceber!

Joana: Baiano também dá passe igual preto-velho, eu trabalho muito com meu baiano, mas as pessoa que vem aqui é por causa do Pai Benedito, elas ainda não tão preparada pra isso, devargazinho eu vou trazendo."

(Depoimento Joana - 23/04/2006)

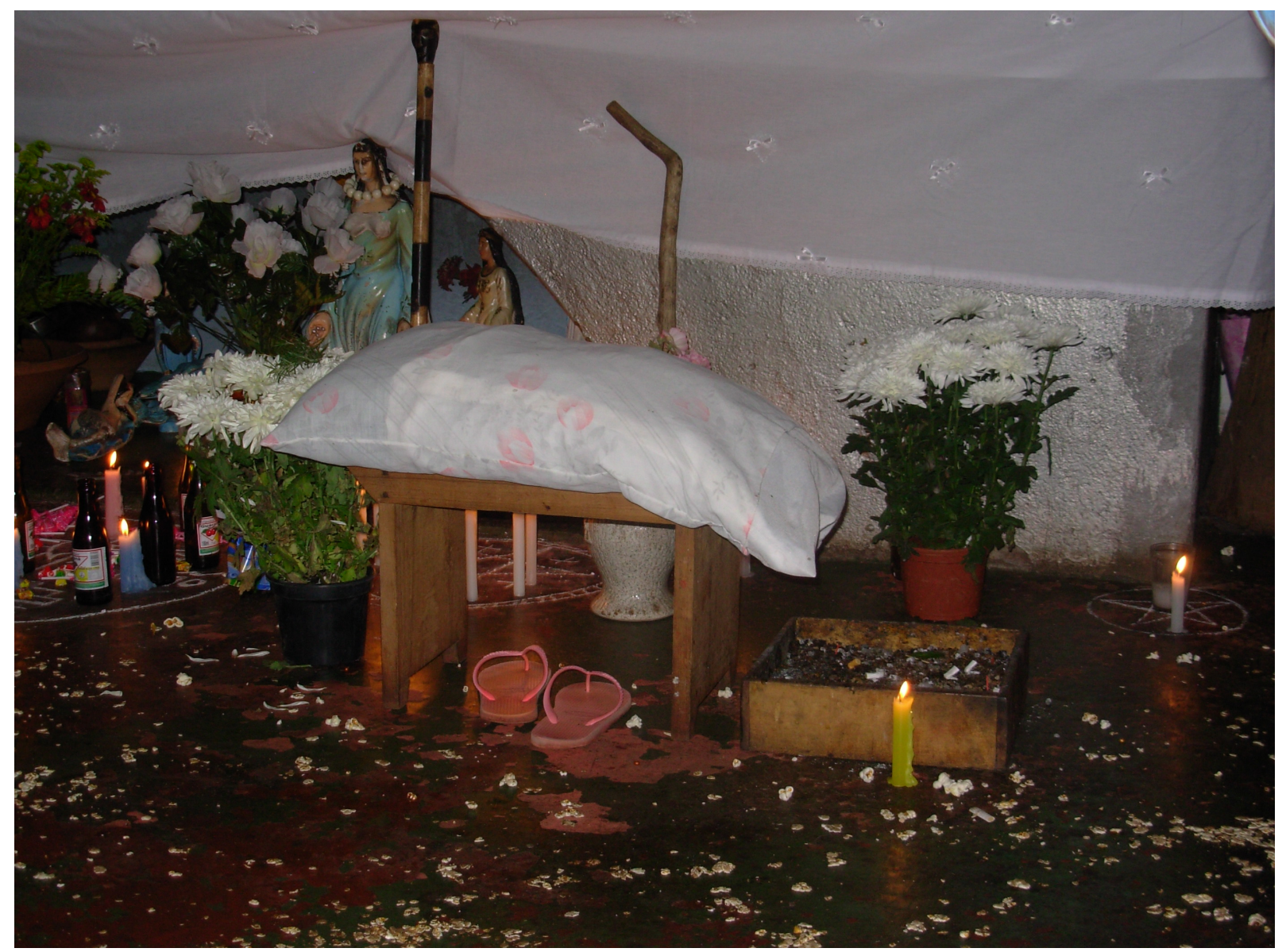

Figura 3: Vela amarela ao lado do banco de Pai Benedito. 
As velas aparecem nas histórias como uma representação sensível da alma ou espírito.

Nessas articulações entre significantes, feitas por deslizamento, surgem as metonímias que podemos encontrar por a toda parte, nesse terreiro e também na umbanda. Dessa forma, uma pena nos remete ao caboclo, a rosa vermelha quer dizer uma pomba-gira, rosa branca preto-velho ou Iemanjá. Segundo Quinet (2000), a metonímia aparece como o que dá a característica do desejo. Logo, sendo o desejo marcado pela falta, a metonímia vem anunciar aquilo que não se tem. Assim, não obstante ausente ou intangível, a entidade se mostra "metonimicamente" presente por meio de algum elemento (significante) do contexto dela e não desampara o filho fiel.

A umbanda é assim "cheia de milindre" como Joana gosta de dizer. Não basta pensarmos que o que está sendo mostrado é exatamente o que aparenta ser. Joana diz várias vezes, por esses e por outros detalhes que existem na prática umbandista, que não acredita como uma pessoa pode dizer-se pai ou mãe-de-santo apenas por estudar alguns livros. Pois, a umbanda "tem muitos ensinamentos" e tudo o que aprendeu foi por ter trabalhado com sua mãe no centro.

Ouvir as narrativas da mãe-de-santo, Joana, possibilita-nos uma articulação com componentes do imaginário social umbandista. Segundo Bairrão (2002, p.58), sobre os umbandistas, é "por vezes difícil diferenciar a vida comum das pessoas, das lendas, dos seus deuses e discernir onde acaba uma roda de samba e começa uma "gira".

Dessa forma, acreditamos que através da escuta das histórias colhidas no terreiro de Pai Benedito e da observação dos significantes revelados como gestos e rituais que são apresentados como forma de superstições no terreiro de umbanda entraremos em contato com as experiências sociais dos indivíduos, que é o que pretende a Psicologia Social.

Já disse Lacan (1960, p. 844) que "o inconsciente é aquilo que dizemos", ou seja, o que insiste e se mostra. E, retomando Barthes, podemos dizer de várias formas e não apenas através de palavras. Numa pesquisa como esta é preciso trabalhar não 
apenas com o dito por palavras (as narrativas), mas também com as suas lacunas e o que se diz por outros meios (atos, minúcias rituais, etc.). As práticas umbandistas, muitas vezes, representam o escondido, a sofreguidão, o desconhecido pessoal e, às vezes, o mal visto, exercendo a função de dar cidadania ao recalcado. Talvez, lidar com elas, seja aprender a respeitar e a elaborar aspectos pessoais e coletivos menos apresentáveis, mas nem por isso menos existentes. 


\section{ASPECTOS METODOLÓGICOS}

Para a realização dessa pesquisa, que a princípio abordaria apenas a entidade exu, procurei estabelecer contato com apenas um terreiro, uma vez que adentrar o universo de uma casa de umbanda demanda tempo e aceitação do pesquisador pelos membros da casa. Sendo a umbanda uma religião que foi, e ainda é muito discriminada, paira um ar de segredo nas falas e atitudes de seus participantes.

No caso, por se tratar de uma pesquisa sobre exus, essa figura tão polêmica do panteão umbandista, muitos terreiros, embora não seja a verdade, dizem não trabalhar com tal entidade. Assim, o terreiro de Joana, sendo uma casa antiga e tradicional de umbanda com a qual logo se estabeleceu uma simpatia recíproca, e aonde era possível ter acesso às giras de esquerda, definiu-se o que já estava definido: aquele seria meu campo de pesquisa. Para tanto, solicitei à Joana autorização para a pesquisa, formalizada por meio de um termo de consentimento livre e esclarecido (anexo 1).

Vale dizer que Joana também procurou explicitar em suas falas o desejo de que a pesquisa fosse realizada apenas em sua casa:

“Essas coisa de ficar misturando terreiro não dá certo. Por que aqui é uma coisa, aqui a gente faz de um jeito e no otro faz de otro modo. Você entendeu? Que nem aquele menino que vinha aqui (referindo-se a um outro pesquisador), o trabalho dele pudia ter ficado bem melhor, mas acabô ficando confuso."

(Depoimento Joana, 15/10/2005)

Explico: o pesquisador referido acima, segundo Joana, havia sido avisado por Pai Benedito de que ele escreveria um livro sobre o centro. No entanto, quando viram o trabalho pronto - abordando dois terreiros - acharam que poderia ter ficado bem 
melhor se o pesquisador tivesse abordado apenas um terreiro: o de Pai Benedito é claro.

Não sabemos ao certo quais eram as expectativas criadas pela casa sobre a pesquisa em questão. Mas, como o desejo não realizado sempre retorna em busca de satisfação, ao voltar um pesquisador naquele local, lá estava o desejo novamente.

No entanto, aquele desejo encontrou acolhida nesta pesquisa, uma vez que uma das pretensões era adentrar o modo de vida umbandista. E, sabemos que para isso é preciso tempo e aceitação. A escolha de uma única casa para desenvolver o trabalho foi, então, um fator pertinente.

Contudo, com as portas abertas para a pesquisa dos exus, começava um longo caminho por seus labirintos...

Para iniciar meus escritos, peço a mãe-de-santo para que ela autorizasse as gravações durante as conversas que aconteceriam entre mim e as entidades que ela recebe. Só assim a pesquisa poderia começar de fato. Joana logo concorda e marcamos a data para que a entrevista fosse realizada.

Focalizei principalmente as narrativas da mãe de santo não apenas por uma exigência da "etiqueta umbandista" de ter como principal interlocutor a principal autoridade do terreiro. Mas, também, na medida em que pelos seus relatos desfilava boa parta da vida coletiva daquela comunidade.

De acordo com Radin (LANGNESS, 1965 apud CASAL, 1997), nesta situação

“... o objetivo não é o de obter detalhes biográficos sobre um indivíduo concreto [...] mas o de permitir que um indivíduo, de idade e de capacidades médias, descreva a sua vida considerada representativa do grupo social em que ele cresceu. $O$ que mais interessa - acrescenta Radin - é o ponto de vista, assim obtido, a partir do interior da sua cultura".

Quando chego com o equipamento para realizar a gravação, Joana me deixa esperar por duas horas enquanto atende algumas pessoas que a procuram para 
benzer. Fato esse que nunca ocorre, pois nem Joana e nem Pai Benedito gostam de deixar as pessoas à sua espera. Sempre procuram mandar algum recado para quem os espera. No entanto, nesse dia Joana não estava incorporada e também não benzeu durante todo o tempo em que esperei, mas seu olhar desviava-se do meu e também não me incluía na conversa como é o seu costume. Dessa vez procurou um lugar para se sentar bem longe de onde eu estava.

Durante a espera várias hipóteses passavam pela minha cabeça, mas como eram apenas suposições e eu já havia esperado tempo suficiente para que ela se pronunciasse, logo, me dirijo a Joana para saber como poderíamos fazer para gravar as entrevistas já que não parava de chegar gente para benzer. Então, proponho outro dia.

Mas Joana, sem olhar nos meus olhos, responde que na noite anterior ela havia pedido a Meire (sua irmã e mãe pequena) que pedisse a autorização de Pai Benedito para a realização da gravação e ele havia negado o pedido. Contudo, Joana pede para que eu volte na gira do dia seguinte para que tente gravar as entrevistas com Pai Benedito, o baiano e o exu. Diz que talvez se os pegasse de "supetão" a entrevista poderia ser concedida, mas ela achava que mesmo assim seria difícil porque "entidade que é entidade não faz essas coisas não".

Contudo, quando volto para tentar a entrevista com as entidades, tanto o preto-velho quanto o baiano se recusam dizendo que nem sabem o que é esse tal gravador, que aquilo não era do tempo deles, e já que não conheciam, não iriam fazer, mas eu poderia perguntar o que quisesse a eles. Quanto ao exu, ele me dá a mesma resposta que os demais, acrescentando que quem faz isso são só as mulheres $^{2}$ - referindo-se as pombas-gira -, e me diz que Joana poderia conceder entrevistas gravadas, mas as entidades não. Então pergunto por que as pombas-gira não se importam de se deixarem ser gravadas e ele me diz: "essas são tudo assanhada!".

\footnotetext{
${ }^{2}$ Esclareço que concomitantemente à minha coleta, outra pesquisa, especificamente sobre pombas giras, era parcialmente desenvolvida no terreiro e para esta havia sido dada autorização para fazer gravações.
} 
Portanto, respeitei as exigências do chefe do terreiro, Pai Benedito, e com sua autorização anotei nossas conversas, procurando ser o mais fiel possível às falas dele e das demais entidades.

Valendo-me do método etnográfico, considerado o mais apropriado ao tipo de estudo que eu desenvolveria, o qual requer uma imersão do pesquisador na situação estudada com o objetivo de descrever a comunidade "por dentro", passei a freqüentar o terreiro rotineiramente. Por volta de seis meses, compareci uma vez por semana, fui a giras abertas e fechadas. Em seguida, por mais seis meses, compareci em todas as giras noturnas oferecidas pela casa, como também freqüentei as festividades familiares da mãe-de-santo. Realizei entrevistas livres com a mesma, no período vespertino e também com alguns médiuns da casa. As entrevistas com a mãe-de-santo foram gravadas em Mini-Disc, assim como algumas giras também foram gravadas e filmadas. Não foi utilizado um roteiro de entrevista, portanto elas foram livres, e à medida em que os assuntos iam surgindo através de acontecimentos do cotidiano a conversa se desenrolava. Também fiz uso de um diário de campo para registrar as impressões do local e também anotar conversas com guias que não puderam ser gravadas. Fotos também foram tiradas.

Dessa forma, através da observação participante, ou melhor dizendo, da participação observante ("trabalhei" também como cambone, auxiliando os médiuns durante as giras), pude demonstrar na prática (o que é muito importante para essa comunidade) o meu respeito à crença e ao trabalho espiritual ali desenvolvido, assim como também pude ampliar minha visão/audição do fenômeno, já que estava em contato direto com médiuns e consulentes.

Não necessariamente o pesquisador de religiões afro-brasileiras precisa trabalhar como cambone para obter alguma informação. No caso, as situações de auxilio foram ocorrendo naturalmente, através de pedidos dos próprios médiuns, uma vez que havia poucas pessoas para atender as solicitações das entidades e eu estava próxima a eles, por fazer minhas anotações dentro do congá.

Segundo Bairrão (2005, pp.446) 
"os níveis de revelação do fenômeno são proporcionais ao modo de abordá-lo e a escuta participante é também uma propedêutica ao deciframento das semioses em jogo".

Assim, é preciso não criar barreiras sobrepondo o saber acadêmico ao popular para que o outro possa revelar-se.

Mas, o que parecia estar fluindo tão bem entre pesquisador e campo precisou ser interrompido, "trancado".

Começam, aqui, exus a se revelarem através de seus caminhos sinuosos.

Engravido e por conta disso fico proibida pela casa de participar das giras de esquerda. Por quê?

Segundo Joana, as "vibrações" que circulam nas giras de esquerda são muito fortes e não fariam bem a criança que eu estava gestando. Além disso, há um senso comum umbandista que afirma exus e pombas-gira (a esquerda) não gostarem de crianças. No entanto, outras giras puderam ser freqüentadas.

Numa de minhas diversas tentativas de abandonar a pesquisa, surge a fala de Pai Benedito aconselhando-me a não começar meu trabalho escrevendo sobre a esquerda (sobre os exus), pois ele achava melhor eu começar falando "da outra parte da casa".

Apesar das diversas leituras realizadas sobre o método etnográfico e do conhecimento das críticas a um descolamento entre os objetivos do pesquisador e as regras existentes no campo, que se não possibilitam ou inviabilizam a realização do trabalho certamente o refinam, me peguei na mesma posição daqueles que eu criticaria. Ao chegar ao terreiro de Pai Benedito pura e simplesmente revelei o meu desejo de pesquisar os exus e falar do envolvimento daquela casa com a referida entidade, sem levar em conta o lado reservado deste aspecto do culto na umbanda nem me dar conta de que muitas vezes é se escondendo que eles se mostram.

Em que momento olhei para o desejo da comunidade?

Assim, mais uma vez recorro ao Pai Benedito e ele me diz: 
“...faz tempo fia que você sabe que precisa tratar da sua cigana, as veis não é pra começá falando daquele homem (exu), primero ocê precisa cuidá dela, acendê as vela dela."

(Depoimento Pai Benedito, 07/06/06)

Rendida à minha obrigação com a cigana, começo a acender velas alaranjadas todas as semanas no local designado aos ciganos. Busco conhecer mais sobre essa entidade de quem haviam me falado desde a primeira vez que tinha pisado naquele centro. E várias questões vão se abrindo na minha mente.

Percebo que à medida que vou conhecendo mais sobre a "cigana", conheço mais a mim mesma e surgem novos rumos para a pesquisa realizada naquela casa.

Com efeito, para mim "conheça-te a ti mesmo" não foi apenas uma mensagem inscrita na entrada do templo de Apolo. Assim como Sócrates, Pai Benedito também aconselha, à sua maneira, a conhecer a si mesmo. E, para entrar em sua casa, primeiro é preciso conhecer a si próprio.

O que eu queria falar sobre aquele homem (o exu)? Primeiro deveria sair da escuridão da minha caverna, buscando a luz dentro de mim para que eu pudesse enxergar o outro, ou melhor, o que o outro queria e estava me dizendo nas entrelinhas.

De acordo com Leme (2005, p.23-24),

\begin{abstract}
"uma postura muito neutra em relação ao envolvimento com o campo leva a um conhecimento superficial desta religião. Muitas vezes torna-se necessário colocar-se na condição de consulente, filho da casa, já que, transferencialmente nos é dado, queiramos ou não, um lugar que leva em conta essa posição."
\end{abstract}

Entre tantas histórias, surgiu a possibilidade de usar instrumentos da história oral, utilizada aqui como uma técnica para armazenar, transcrever e conservar o acervo oral que me chagava as mãos, ou melhor, aos ouvidos. Ela aparece como um 
recurso a mais de informação para me ajudar na construção da percepção daquela comunidade. Através dela, ao longo de todo o tempo, os dados colhidos foram comentados, refletidos com os participantes e o produto foi a historia coletiva da comunidade construída e descrita por ela, depois de transcritas as possíveis gravações. Com a história desta comunidade religiosa posta em formato textual, reli o texto com Joana, para que ela fosse retificando e ratificando-o, caso percebesse necessidade. Técnica que contribuiu para que novos depoimentos surgissem.

Ao fazê-la resgatei concepções umbandistas sobre o significado da participação do morto no contexto psicológico individual e comunitário. Os registros foram discutidos de acordo com a própria visão de mundo do grupo a que pertencem, valendo-me de conhecimentos advindos da psicanálise lacaniana, a qual não atribui significados ou cria hipóteses explicativas, mas sim nos oferece a oportunidade de refinar nossa escuta, possibilitando um acesso ao universo inconsciente (BAIRRÃO, 2005).

Uma vez que Lacan já disse estar o inconsciente estruturado como linguagem, apenas refinou-se a escuta de sentidos explicita ou implicitamente enunciados. Ou seja, não se tratou de interpretar psicanaliticamente as produções religiosas, isto é, de substituir o modo próprio de descrição dos fenômenos religiosos proporcionado por aqueles que os vivenciam, por uma explicação que os traduza num idioma psicológico como a psicanálise. Isso seria violar o modo como efetivamente se apresentam e proporcionam, ou seja, em ultima instancia não lhes dar ouvidos, desautorizando as experiências e os conhecimentos intrínsecos ao modo de vida próprio da sua constituição e aparição.

Com efeito, procurei fazer algo semelhante à idéia de Mantovani e Bairrão (2005), quando dizem que ao levarmos a escuta psicanalítica aos terreiros, o que temos é um instrumento que permite o reconhecimento do outro, no caso os religiosos e seus significados profundos, que vão além das informações corriqueiras, mas talhadas e relatadas pelos próprios informantes, tomados como sendo sujeitos 
além da sua consciência, enunciantes em vários lugares onde a subjetividade se expressa, como na música, nos gestos, nos diálogos interpessoais, etc.

Dessa forma, não analisei as descobertas realizadas em campo, se por interpretação se entender a redescrição das suas vivências num vocabulário psicanalítico, o que mais propriamente poderia ser definido como uma redução psicologizante. Em vez disso propus-me a refleti-las de maneira a que a sua compreensão e a vida cotidiana da comunidade pudessem ser ouvidas através de relatos dos próprios depoentes e nos seus próprios termos, sem nenhum acréscimo discursivo de sentidos explicita ou implicitamente já lá articulados.

Após estes esclarecimentos, posso agora seguir minha meta... 


\section{O TERREIRO}

"Conheceis a história.

Contudo, iremos repeti-la.

Todas as coisas já foram ditas, mas como ninguém as escuta,

é preciso recomeçar sempre.

(André Gide, em "O tratado de Narciso")

\section{1 - O ESPAÇO}

Popularmente conhecido como "Centro da Joana ou Terreiro da Joana" por seus freqüentadores, o terreiro foi batizado por "Tenda Espírita Umbanda Pai Benedito", sendo esse o nome grafado em uma placa escondida, que fica pendurada do lado de fora da casa.

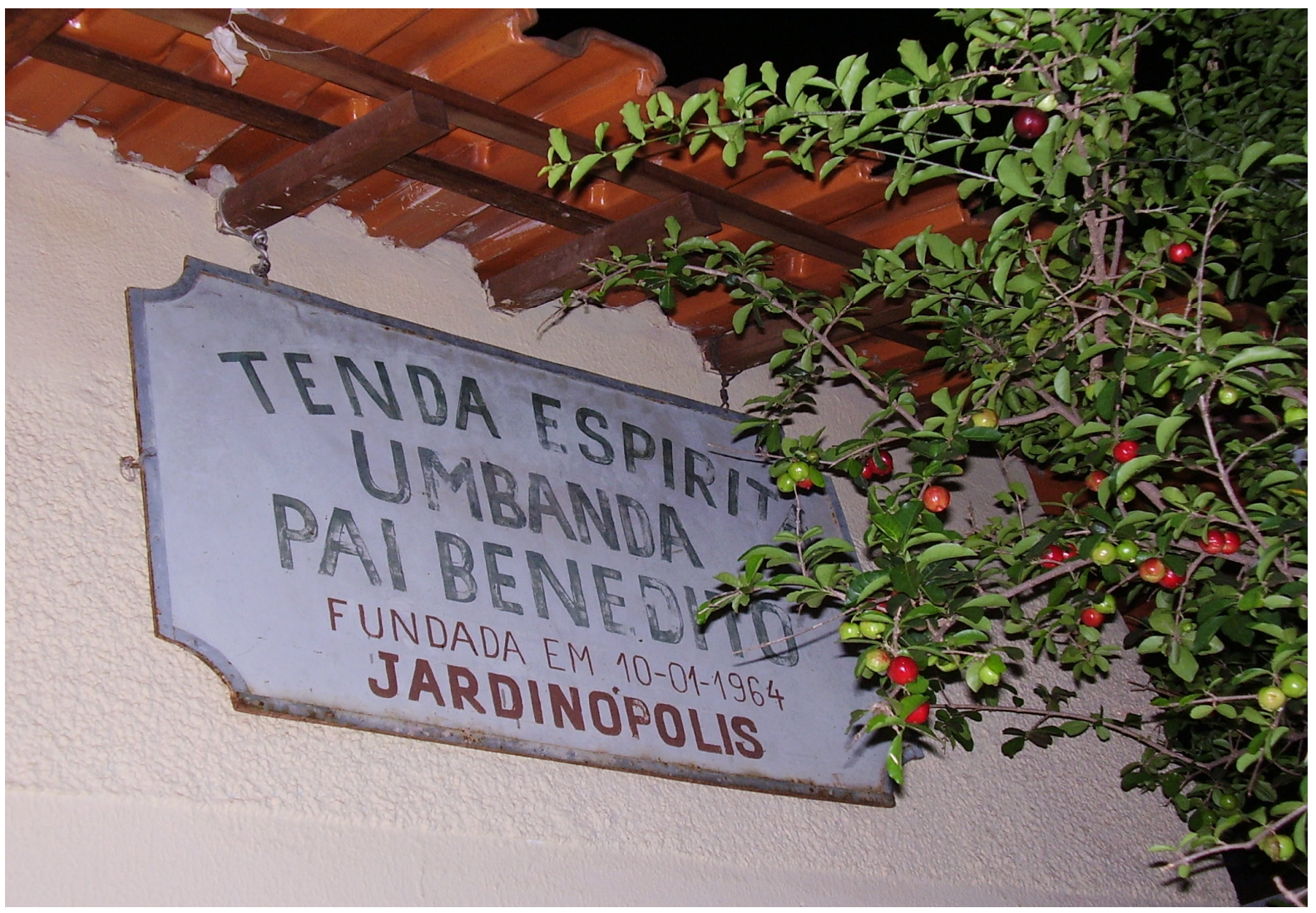

Figura 4: Placa de identificação do terreiro. 
Ao chegarmos perto do local, nos dias de gira, podemos sentir o cheiro peculiar de velas queimadas misturado ao cheiro de mato da região, deliciosamente trazidos pela brisa fresca da cidade.

Vale dizer que Jardinópolis é uma simpática cidade paulista, conhecida como capital nacional da manga e vizinha de Ribeirão Preto, o maior pólo sucroalcooleiro do país. Conta hoje com cerca de 34 mil habitantes. Durante minhas idas e vindas dessa cidade pude acompanhar a instalação dos seus únicos três semáforos. Também pude ver o leiteiro, em sua carrocinha azul, entregar leite em garrafas de vidro pela manhã - coisas que ouvia minha mãe contar de sua infância e que jamais imaginaria ver - e pela tarde, essa mesma carrocinha sai pelas ruas a vender verduras. Como também pude ver um grupo de pessoas pelas ruas acompanhando um funeral.

$\mathrm{Na}$ semana que antecede o seis de agosto, podemos ver a cidade se enfeitar para receber neste dia, milhares de romeiros da região que chegam para a Festa da Lapa, em comemoração ao dia do Bom Jesus da Lapa, santo padroeiro da cidade.

Retornando ao centro de Pai Benedito, numa rua mal iluminada, encontramos, a sua frente, um enorme terreno baldio e, ao lado, uma escola municipal. O bairro é simples e, no caminho, sempre nos deparamos com pessoas sentadas na calçada ou pelas ruas e esquinas.

Chegando ao nosso destino, avistamos a placa indicativa da casa de umbanda. Diante dela está um formoso pé-de-acerola buscando seu espaço entre o centro e o muro de entrada. Nesse muro existe também uma placa sinalizando os dias e os horários de atendimento ao público e uma porta estreita como entrada. Ao passar por ela, do lado esquerdo, podemos ver uma "casinha" toda fechada (não há como ver por dentro). Nesse local está a "casa das almas", como diz Joana. Segundo ela, nesse local estão algumas imagens.

A entrada por essa via é feita, geralmente, pelos consulentes, pois os médios e os freqüentadores habituais das giras entram pelo portão grande que fica ao lado, sempre aberto. Em seguida, os médios passam pela porta lateral do centro aonde saem em um pequeno corredor que separa a tronqueira do restante do terreiro. Esse 
grande portão pertence à entrada dos fundos da casa da mãe-de-santo. Assim, o terreiro fica ao fundo da casa de Joana.

Nesse terreno, onde está a casa e o centro de Joana, também há outras duas casas e um pequeno quarto. Nessas casas moram os irmãos de Joana. No quintal comum a todas as casas tem sempre vários gatos pretos, um cachorro preto e algumas galinhas, também pretas.

Para que o leitor possa visualizar o que descrevo, exemplifico:

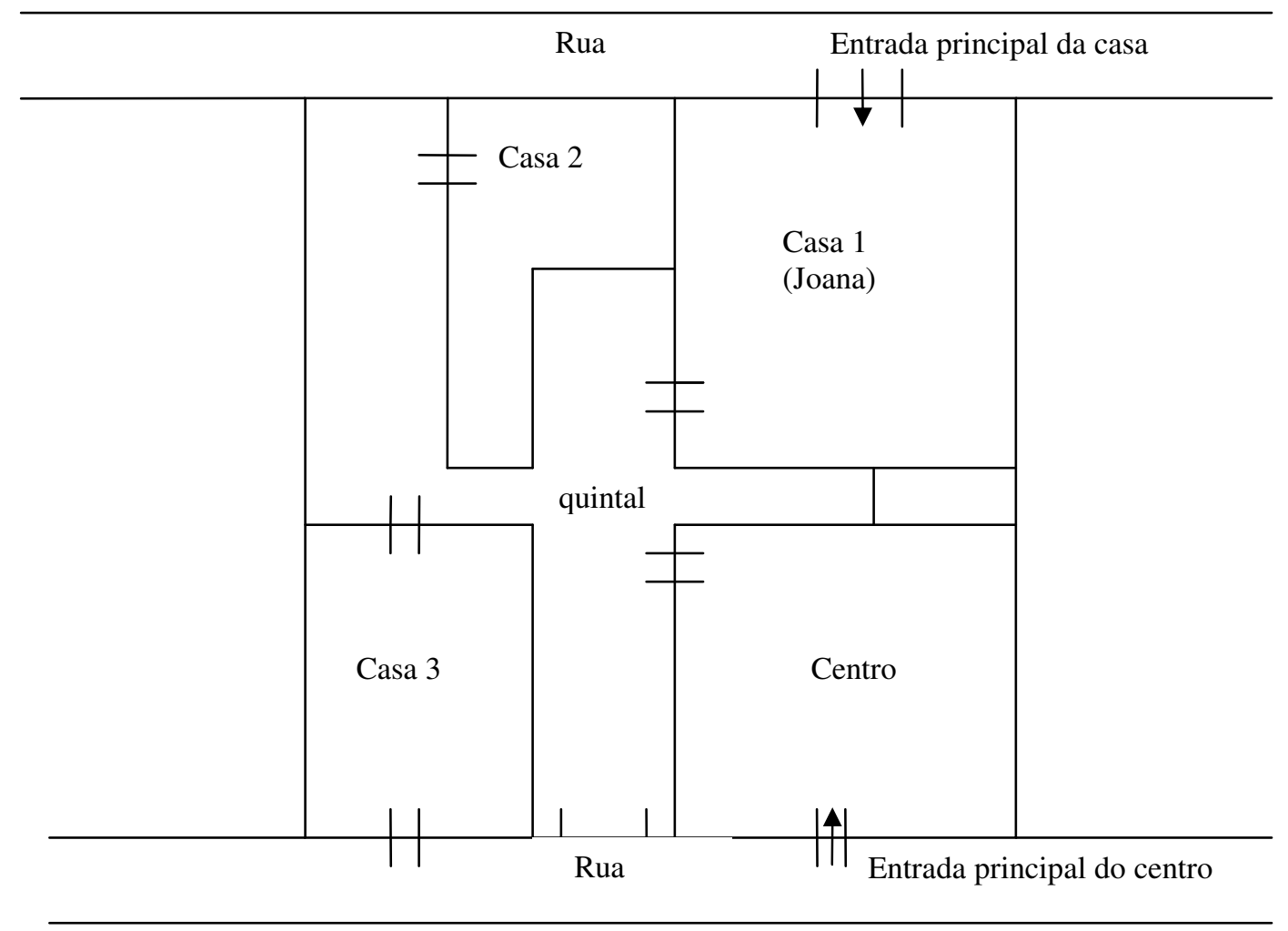

Adentrando o centro, como é chamado pela mãe de santo e os demais médios, na posição de consulente, vamos nos deparar, hoje, com cadeiras de plástico brancas e enfileiradas. Há cerca de um ano atrás, existiam compridos bancos de madeira, do lado direito e esquerdo, misturados a dois sofás corroídos pelo tempo. Essa parte do centro é destinada aos consulentes e fica separada do local da gira por uma mureta (medindo cerca de 1 metro de altura) com uma pequena passagem no meio, para 
que os mesmos possam chegar até as entidades para conversarem no momento do passe.

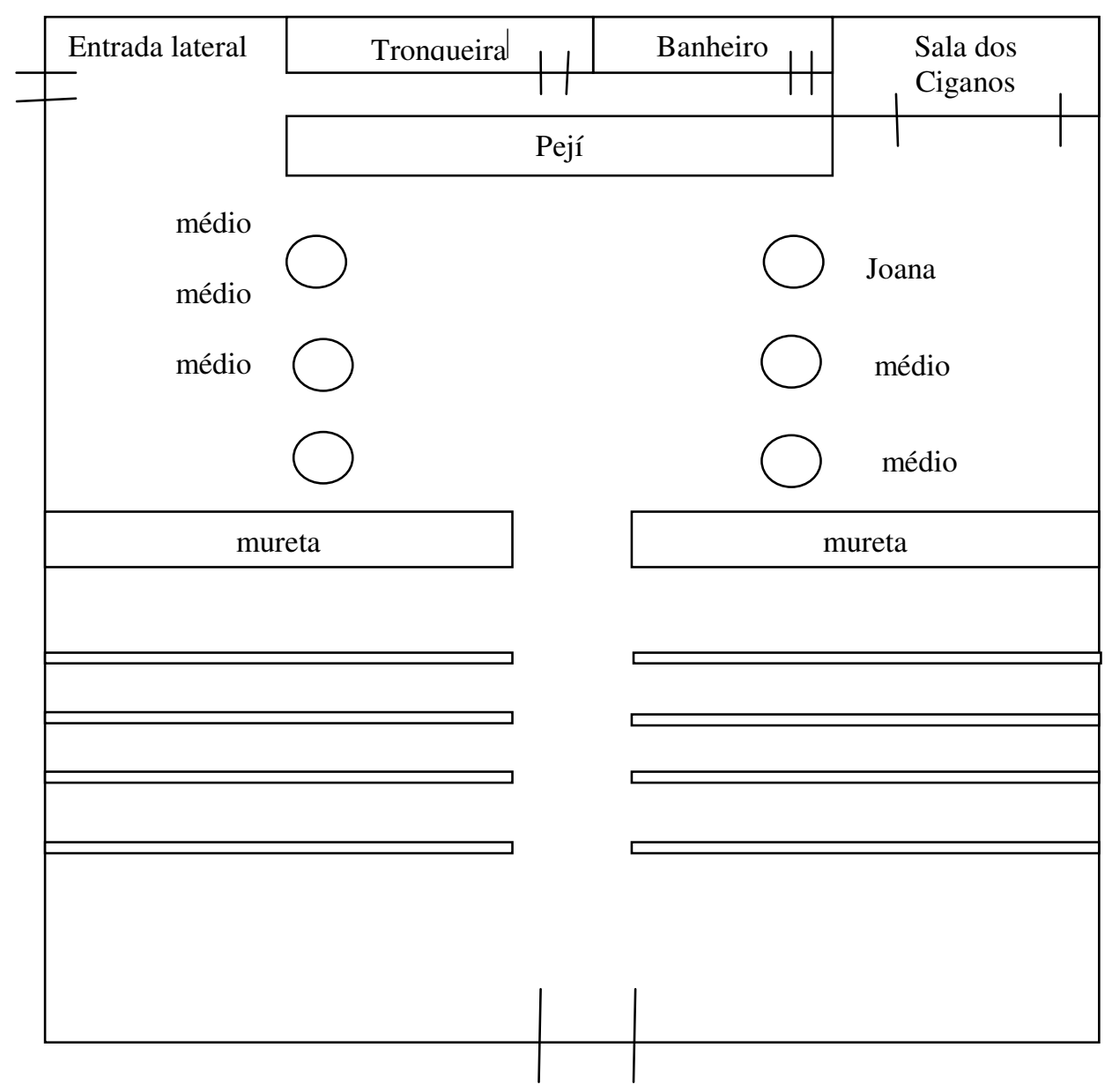

No espaço onde ocorre a gira, congá, existem vários bancos pequenos de madeira que normalmente ficam amontoados em algum canto esperando o momento da gira para serem usados, pois eles servem para que os médios, incorporados por suas respectivas entidades, possam sentar-se para atender o consulente. Vale dizer que na casa, as entidades que se sentam para benzer são os pretos-velhos. Também é colocado mais um banco em frente ao médio para que o consulente possa se acomodar e falar com a entidade. Esses bancos são levados para lugares pré-determinados, dentro do congá, no momento do passe, pois cada cambone sabe onde deve assentar o banco de seu médio. 
Quanto à disposição dos lugares, a mãe-de-santo senta-se, sempre, de costas para o pejí*, no lado esquerdo do mesmo e de frente para a assistência, numa posição em que pode ver todos os médios trabalhando também. Os demais médios sentam-se de costas para as paredes laterais, formando-se duas fileiras, uma em cada parede, estando todos eles frente a frente uns com os outros.

As paredes do terreiro são todas brancas e com vários quadros pendurados. Alguns são de preto-velho, outros de preta-velha como Tia Maria, de Santa Bárbara (Iansã na umbanda), da Santa Ceia, Nossa Senhora da Rosa Mística e alguns "pontos riscados" grafados em ferro. Ao lado direito do pejí (visto de frente), está um quadro grande de D. Chiquinha e abaixo dele existem outros, menores, de Allan Kardec e Eurípedes Barsanulfo (importantes figuras do espiritismo kardecista).

Em alguns locais pode-se ver, a imagem de um Baiano e a imagem de Zé Pilintra, em cima de uma das portas há alguns símbolos grafados em ferro.

O chão do terreiro é de cimento batido ou queimado, pintado de verdebandeira. Nele encontramos, perto do quadro de D. Chiquinha, uma variedade de caixas e sacolas espalhadas com velas, bebidas e fumos, todos donativos para o centro ou entregas para trabalho particular.

Também no chão, duas tabacas (atabaques) podem ser vistas logo abaixo da janela, na lateral esquerda do terreiro. Eles são os objetos preferidos das crianças que entram no terreiro, não há como passar por eles e não dar uma batidinha de mão. Depois do nascimento de Mateus (filho da mãe pequena), a dupla de atabaques ganhou a companhia de um atabaque bem menor, que fica para Matheus e Gabriel (neto de Joana) brincarem.

Perto da entrada ficam as imagens dos ciganos e, entre caixas e sacolas, está um mancebo. Nele são deixadas as saias utilizadas pelas médias durante o trabalho. No terreiro não existe vestiário, então as mulheres, ao chegarem ao centro, vão até o mancebo e pegam suas saias para se vestirem. Os homens vão prontos. 
Existe apenas um banheiro atrás do pejí e ao lado da tronqueira. Também não existe bebedouro no local. Nos dias quentes, tem sempre algum familiar para buscar água fresca na casa de Joana, assim que termina a gira.

\section{2 - AS IMAGENS}

Imagens estão por toda a parte.

Além dos quadros já referidos, o pejí merece atenção especial.

Sempre exposto, ao contrário de alguns terreiros em que é descoberto apenas nos momentos de gira, ele conta com aproximadamente duzentas imagens de santos, orixás e entidades.

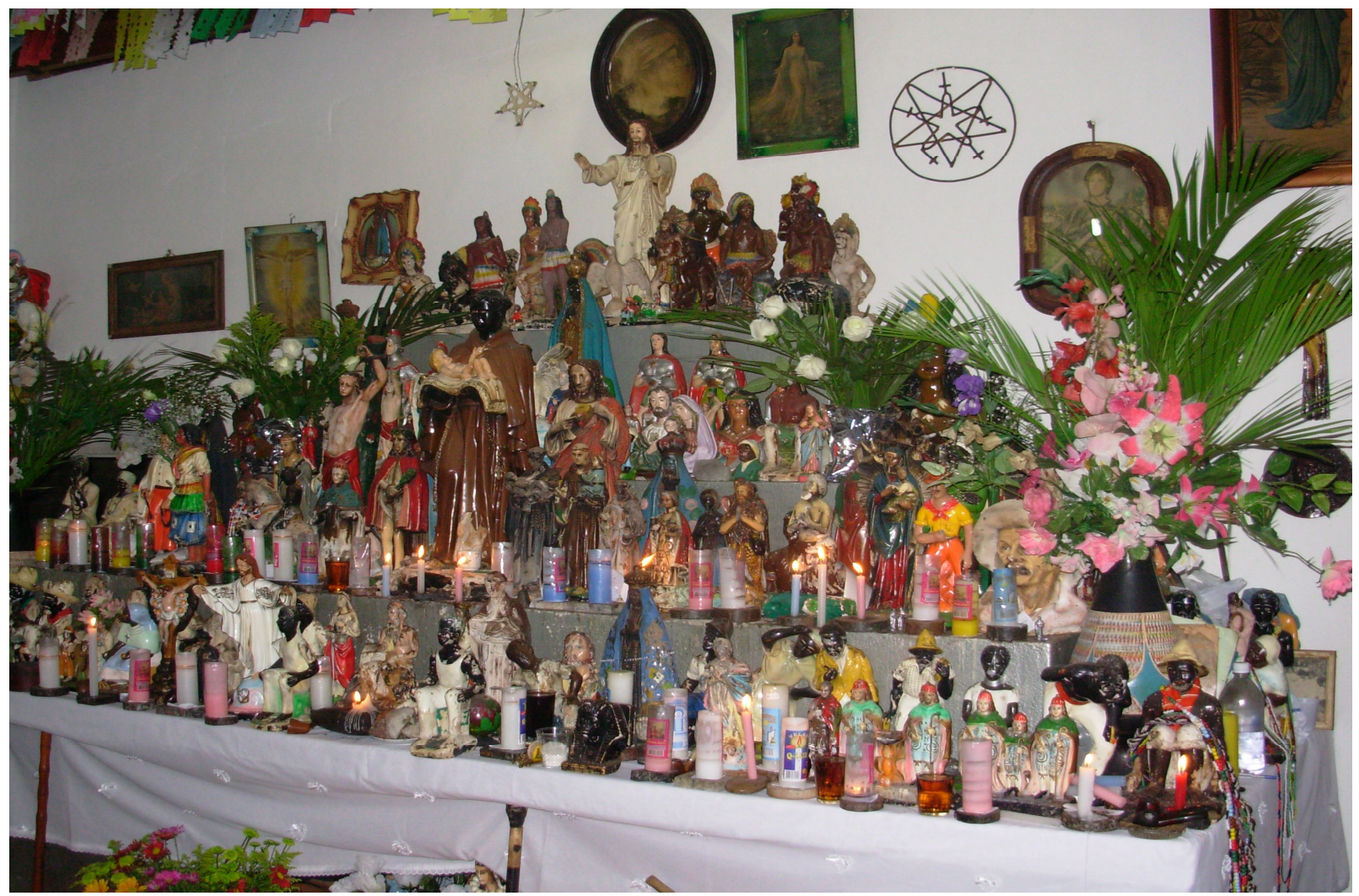

Figura 5: Pejí. 
Segundo Joana, algumas dessas imagens foram trazidas por outras pessoas que as deixaram de cultuar e as trouxeram de presente para a casa.

De acordo com Joana:

“...a vida de mãe ou pai-de-santo não é tão fácil quanto os otro pensa, ser mãe ou pai-de-santo é um dom que a pessoa já nasce, não adianta querê estudá que isso não aprende em livro."

( Depoimento Joana - 18/06/2006)

Entre as imagens existem sempre vasos de flores naturais ou artificiais, velas de 7 dias ou velas comuns que geralmente são acesas a pedido dos consulentes, a pedido das entidades no momento do passe, ou pela própria Joana, o que confere ao local um brilho peculiar. Também há sempre copinhos com guaraná para os "cosminhos", café para os pretos-velhos e cerveja para os baianos.

Entre um pé de santo e outro, sempre se encontram tirinhas de papel com nomes e pedidos de ajuda.

No pejí, encontramos as entidades distribuídas da seguinte forma: Jesus Cristo no topo e abaixo dele os caboclos, a seguir os baianos e ciganos e no andar mais baixo estão os pretos-velhos e os cosmes. Fato curioso é a imagem de São Benedito bem no centro do pejí, pois essa imagem é a maior de todas, até mesmo maior que a de Jesus Cristo. Segundo Joana é porque este santo é o chefe dos pretos-velhos. Vale dizer que São Benedito foi um santo italiano, nascido por volta de 1524, no seio de uma família pobre e era descendente de escravos oriundos da Etiópia. Algumas versões dizem que ele era um escravo capturado no norte da África, o que era muito comum no sul da Itália nesta época. Neste caso, ele seria de origem moura, e não etíope. De qualquer modo, todos contam que ele tinha o apelido de "mouro" pela cor de sua pele (WIKIPEDIA, 2009).

Rentes ao chão estão as imagens de Iemanjá e, à sua frente imagens de pontos riscados de baiano, caboclo e preto-velho. Em cima deles há sempre velas acesas, às 
vezes com pedidos em tiras de papel na sua base e também uma ou outra oferenda, como cerveja para os baianos ou charutos para os caboclos.

Durante os atendimentos algumas entidades também pedem aos cambones para que coloquem o nome do consulente em algum ponto.

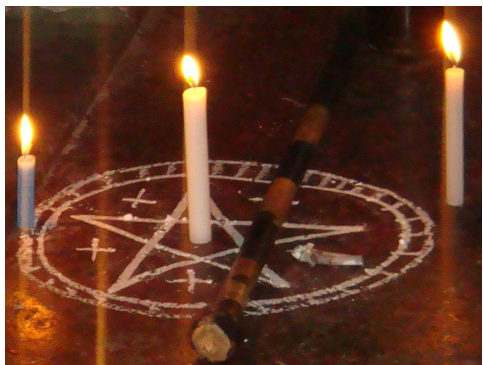

Figura 6: Ponto de preto-velho.

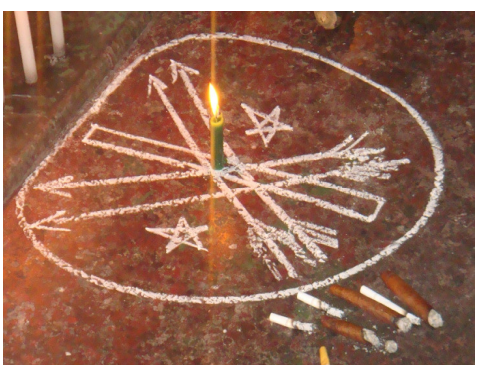

Figura 7: Ponto de caboclo.

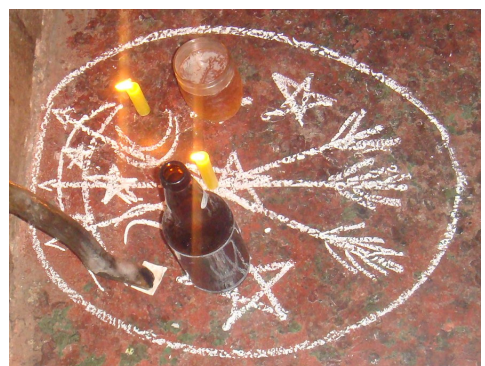

Figura 8: Ponto de baiano.

Escoradas na toalha do pejí, as bengalas que aparecem na foto são para os pretos-velhos.

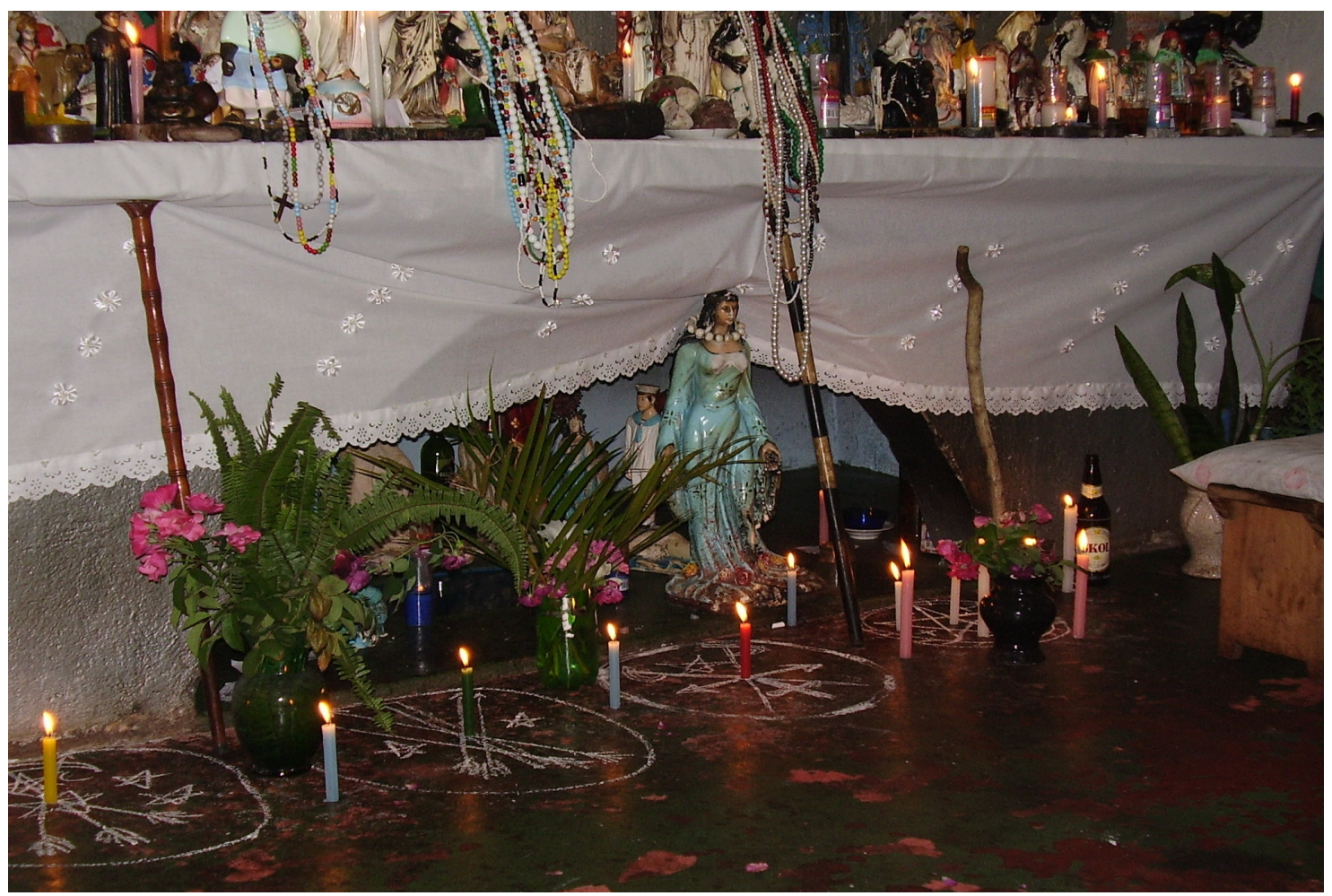

Figura 9: Parte inferior do pejí. 
No local destinado aos preto-velhos no pejí, está uma imagem de Pai Benedito, entidade recebida por Joana, e que era de sua mãe. Essa imagem fica bem atrás do acento de Joana, no conga. Nela Joana deixa suas guias penduradas, as quais são retiradas apenas nos momentos em que Joana as usa para benzer, alguns outros médios também fazem o mesmo.

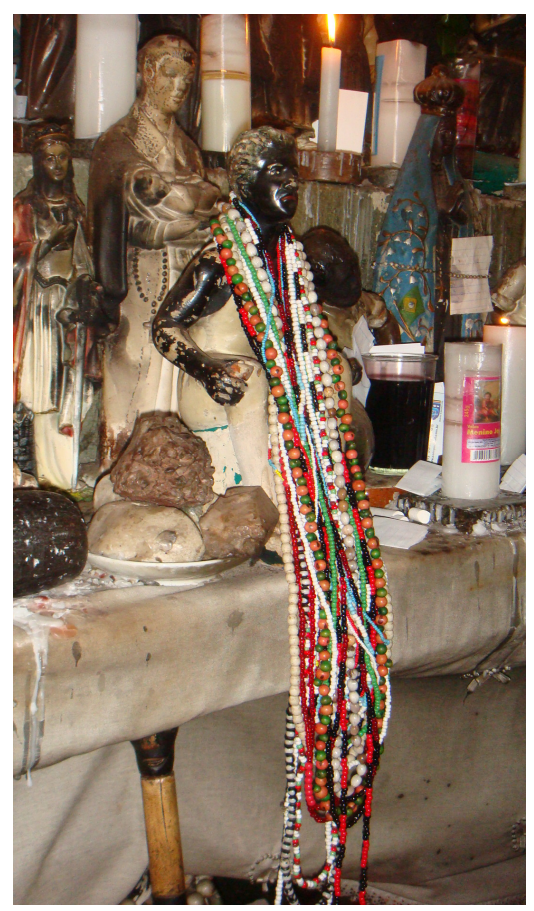

Figura 10: Imagem de Pai Benedito

No lado esquerdo do pejí, existem dois degraus. Ao descermos, nos deparamos com uma porta fechada por uma cortina vermelha, e que nos leva a uma minúscula sala onde estão as imagens dos ciganos. Encontra-se também uma pequena mesa onde Meire, a irmã de Joana e mãe pequena do terreiro, recebe sua cigana, a Jacira, e faz suas consultas com as cartas ciganas. Ainda nessa sala, encontramos os pratos com moedas, canela, folhas de louro e cravo para que as velas sejam acesas. A luz que entra nesse espaço chega através das frestas da cortina vermelha e das velas que estão no local, predominando uma cor avermelhada nas paredes. O cheiro é muito 
peculiar, uma mistura misteriosa de incensos, velas, especiarias e bebidas que ficam nas taças ofertadas aos ciganos.

Posso dizer que essa é a área mais luxuosa do terreiro.

Joana diz não gostar muito de trabalhar com cigano porque acha o trabalho muito demorado. Segundo ela, os ciganos falam muito e é preciso estar pronta "espiritualmente" a todo momento para receber outras entidades e atender as pessoas que ali chegam. Assim, Joana prefere apenas "passar essa linha" nos dias de trabalhos para saudar o povo cigano.

E a tronqueira?

Pois bem, a tronqueira é o segredo do terreiro, sua defesa.

Segundo Joana, existem muitas demandas* entre os terreiros e não é bom que os demais saibam quais são os guias que ali trabalham na defesa da casa. Mas posso revelar que a tronqueira é tão rica em imagens quanto o pejí. A cor predominante do ambiente é o vermelho e o cheiro é uma mistura picante de cigarros, velas, champagnes, whiskys, cachaças, rosas e pimentas. Ingredientes que aguçam nossos sentidos e nos fazem sentir ora medo, ora poder.

Também há outros lugares sagrados no terreiro.

E, mais imagens espalhadas pelas paredes podem ser vistas. 


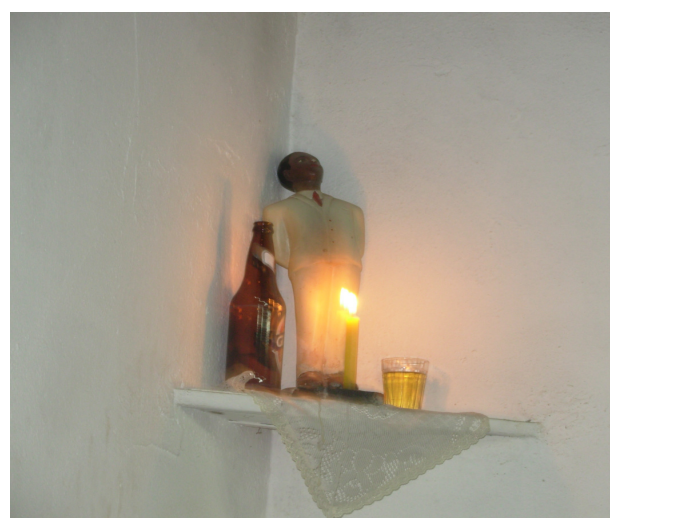

Figura 11: Baiano.

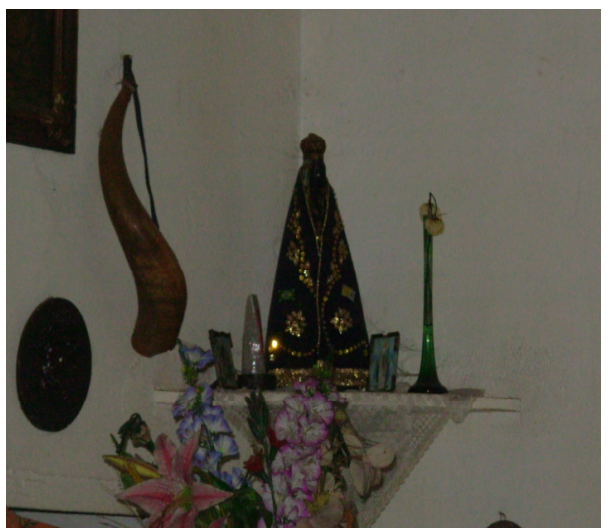

Figura 13: Nossa Senhora Aparecida.

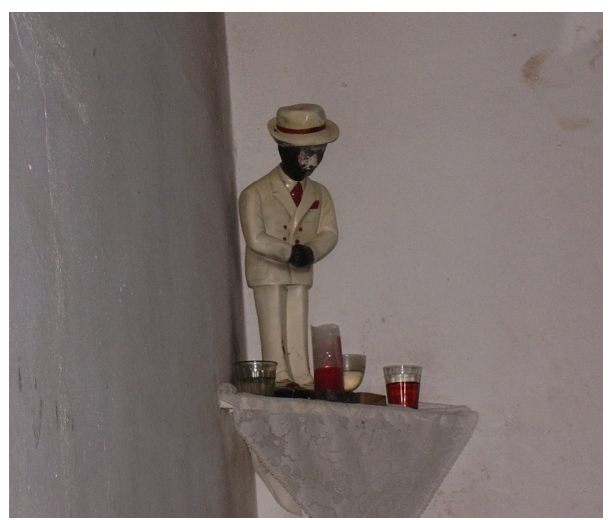

jura 12: Baiano Zé Pilintra.

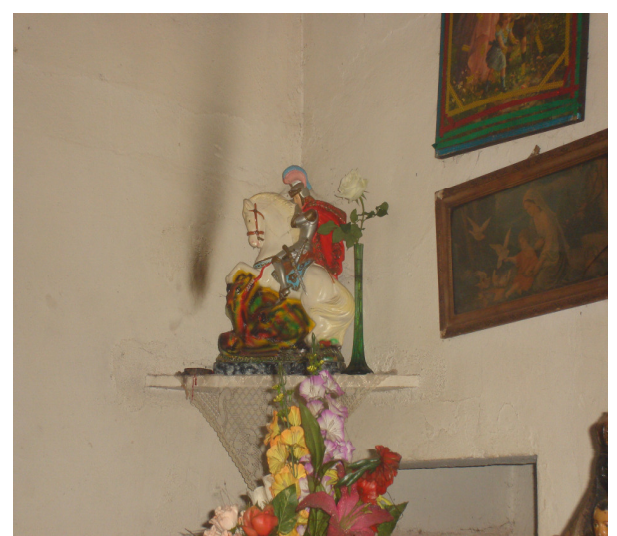

Figura 14: São Jorge.

\section{3 - AS GIRAS}

\subsubsection{Giras no terreiro}

As giras funcionam sempre às segundas, quartas e sextas-feiras. O terreiro fecha suas portas apenas nos dias de Natal, Ano Novo, Sexta-feira Santa, Quarta-Feira de 
Cinzas e 06 de agosto, quando há a grande festa na cidade em comemoração a Bom Jesus da Lapa. Na casa não existem férias, pois Joana diz não haver férias para os problemas, sendo que sempre há pessoas necessitando de atendimento.

A placa no muro informa o horário de início das giras, mas a qualquer hora que você chegar ao centro poderá entrar, pois a porta apesar de fechada nunca é trancada.

Nesses três dias da semana em que a casa funciona, as giras são para a direita e recebem em média de trinta a quarenta pessoas. Apenas às segundas, após o término da gira de direita, começa a gira de esquerda, e, mesmo assim, para esse momento ficam apenas as pessoas mais íntimas da casa, pois a mãe-de-santo espera a assistência ir embora para começar essa segunda parte.

Os consulentes podem ir embora a qualquer momento. Como já foi dito, a porta nunca é trancada, mas, geralmente, a grande maioria vai embora logo após o passe. Há também os que ficam até o final da gira e aproveitam para tomar passe com as entidades que costumam "descer" depois dos pretos-velhos, como caboclos e baianos.

Joana diz que as pessoas não compreendem o trabalho com a esquerda e depois saem falando mal do centro. Contudo, o terreiro também trabalha outras vezes com a esquerda, dessa vez não com gira aberta, mas sempre que houver uma necessidade, o que pode ser uma demanda contra o terreiro ou contra um filho da casa. Podemos entender que isso ocorre quase que diariamente e, assim sendo, essas sessões são realizadas apenas com os médios do terreiro.

O culto para a esquerda é feito para exus e pombas-gira, quanto aos exusmirins, Joana diz não recebê-los no centro porque fazem muita confusão. Então, prefere levar as oferenda para essas entidades em seus locais característicos que são as ruas retas.

As giras de direita são iniciadas com os médios vestidos de brancos e enfileirados. A mãe-de-santo fica de fronte para o pejí e de costas para a assistência, assim como todos os médios. À direita da mãe-de-santo ficam as médias enfileiradas 
e ao lado esquerdo ficam os médios. Todos eles já possuem seus lugares prédefinidos na fila. A mãe pequena ocupando sempre a primeira posição na fila das mulheres e, ao lado dos homens, está o marido da mãe pequena.

Joana inicia a gira rezando o Pai Nosso e a Ave Maria, em seguida sempre diz:

\footnotetext{
“Essas preces ofereço a todos os orixás que vêm prestar caridade, que nos daí força e proteção, tomando conta e descarregando todo o mal e toda perseguição"
}

Dito isso, puxa os pontos cantados e todos a acompanham, inclusive a assistência. Na sua ausência (informo que isso nunca ocorreu, salvo alguns momentos em que está ocupada com alguma outra coisa dentro da própria gira) quem puxa os pontos é a mãe pequena. Há cerca de um ano, enquanto a mãe pequena está envolvida com os cuidados de Mateus (seu único filho, com dois anos de idade), o terreiro conta com a presença de uma futura média de apenas 7 anos de idade, que possui uma voz forte e afinada e conhece todos os pontos cantados. Assim essa pequena média, de voz firme e altiva, toda vestida de rosa (cor que simboliza entidades femininas na linha de Cosme e Damião) puxa os cantos para iniciar os trabalhos. 


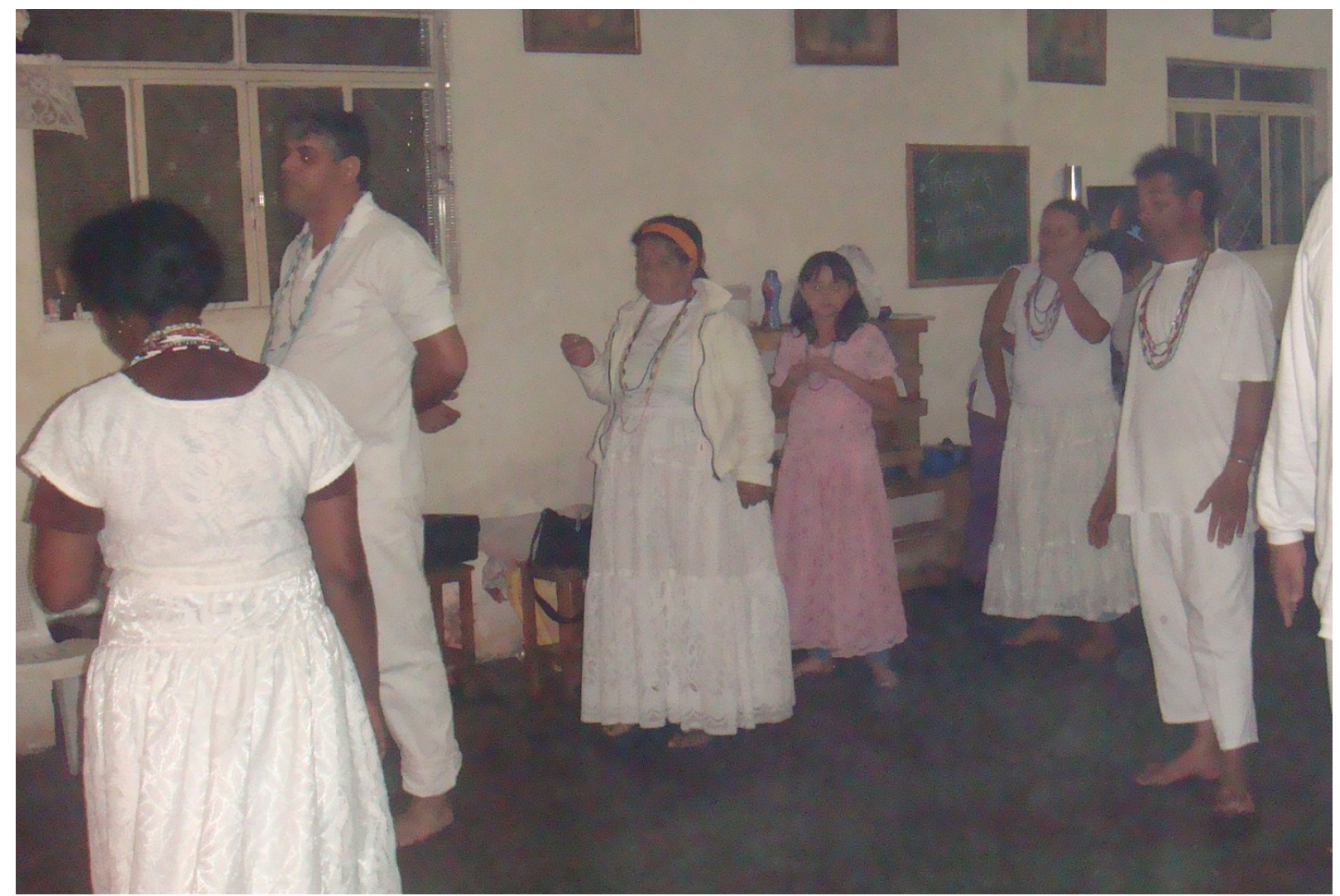

Figura 15: Criança participando da gira.

Os pontos são alegres e às sextas-feiras ganham o acompanhamento dos atabaques.

Eles obedecem sempre à mesma ordem, com raríssimas exceções. Sendo que na primeira parte da gira, ou seja, até o momento do passe, os pontos são oferecidos para os orixás e para os pretos-velhos, sendo eles: Oxalá, Xangô, Iansã, Ogun, Oxossi, Cosme-Damião, Pretos-velhos, Tranca-Ruas. Depois desses, volta-se novamente a cantar para os preto-velhos, contudo, são cantados os pontos específicos para aqueles que ali irão trabalhar. Pode o leitor tomar conhecimento, na página seguinte, de alguns pontos cantados, os quais são uma amostra típica de um repertório muito mais vasto. 


\section{Oxalá}

Oxalá meu pai / Tem pena de nós, tem dó / Se a volta do mundo é grande / Seus poderes são maior / E com a vossa luz / Possamos alcançar / As velas que passou neste congá / E com a vossa luz / Possamos alcançar / As velas que passou neste conga

Hoje é dia de Nossa Senhora / Hoje é dia de nossa Mãe Iemanjá / Calunga eeee, Calunga aaaa / Calunga eeee, Calunga aaaa / Brilham as estrelas no céu / Brilham os peixinhos no mar / Brilham as estrelas no céu / Brilham os peixinhos no mar

\section{Saravá Xangô}

Pedra rolou pai Xangô / Lá nas pedreiras / Segura as pedras, meu pai / Na cachoeira / Tenho o meu corpo fechado / Xangô é meu protetor / Afirma o ponto, meu pai / Pai de cabeça chegou

\section{Saravá Iansã}

Iansã tem seu leque de renda / Pra abanar dia de calor / Iansã mora nas pedreiras / Eu quero ver / Meu Pai Xangô

\section{Saravá Ogum}

Ogum foi praça de cavalaria / E guerreou dez anos em sua frontaria / Um dia ao céu ele passou a major / Agora é ordenança de cavalaria 


\section{Saravá Oxóssi}

Oxóssi é o rei do céu / Oxóssi é o rei da terra / Oxóssi é o rei do céu / Oxóssi é o rei da terra / Ele não desce do céu sem coroa / Sem a mudança de guerra

\section{Saravá Doum (Cosme e Damião)}

Ora Doum São Cosme e Damião / Tem pena de vossos filhos nessa hora de aflição / Ora Doum São Cosme e Damião / Tem pena de vossos filhos nessa hora de aflição / Ora Doum, ei Doum / Eu sou filha de santo, oi Doum / Proteção de Xangô, oi Doum / Eu sou filha de santo, oi Doum / Proteção de Xangô, oi Doum

\section{Saravá os pretos-velhos}

Ora viva meu São Benedito, oi babá / Ele vem de Babu, oi babá / Ora viva meu São Benedito, oi babá / Ele vem de Babu, oi babá / Cadê seu jaculé / Oi ele está em jacundá / Ora vive meu São Benedito, ele vem / Lá do seu jacundá / Ora vive meu São Benedito, ele vem / Lá do seu jacundá

\section{Saravá as almas}

Eu andava perambulando sem ter nada pra comer / Eu pedi a santas almas para vir me socorrer / Eu andava perambulando sem ter nada pra comer / Eu pedi as santas almas para vir me socorrer / Foram as almas que me ajudaram / Foram as almas que me ajudaram / Eu pedi as santas almas / Foram as almas que me ajudaram / Foram as almas que me ajudaram / Foram as almas que me ajudaram / Eu pedi as santas almas / Foram as almas que me ajudaram 


\section{Saravá a defumação}

Eu incensei / Estou incensando / Eu incensei / Estou incensando / A casa do meu Bom Jesus da Lapa / A casa do meu Bom Jesus da Lapa / Nossa Senhora incensou os filhos seus / Ela incensou para cheirar / Assim eu incenso este conga

Vou defumar a umbanda com sete anjos do céu / Umbanda cheira rosa / Rosa cheira guiné

Ao surgir essa música, inicia-se a defumação da casa.

Antes de se iniciar a gira, a panela (tipo frigideira) que recebe as ervas (mirra, eucalipto, benjoim, alfazema,...) para a defumação já está pronta e o encarregado de prepará-la é Orestes. A panela fica do lado de fora do terreiro, apenas à espera de ser puxado o ponto para defumação. Nesse momento, Orestes entra com ela para que a mãe-de-santo a acenda e, então comece a defumação. Joana é a primeira a ser incensada. Depois ele passa a panela pelos quatro cantos do congá e, em seguida, passa com a panela para que os médios sejam incensados. Feito isso, Orestes leva a panela para a assistência e, rapidamente, passa por cada fileira para que cada um possa receber um pouco da fumaça. Todo o centro fica envolto numa nuvem de fumaça e o perfume das ervas penetram tecidos, fios e pele, enquanto a música faz o corpo vibrar com suas batidas. Extasiam-se nossos sentidos.

Vale dizer que, no momento em que as pessoas recebem a fumaça, todos fazem os mesmos gestos: levantam os braços na altura do peito (onde se encontra a panela com a fumaça) e, com as mãos espalmadas para baixo passam fazendo um movimento de abrir e fechar os braços por duas vezes, para que eles se cruzem em cima da fumaça. Após isso, num movimento de levar a fumaça à cabeça, encostam uma das mãos na testa e outra na nuca e depois alternam-se as mãos. Quando toda a assistência foi incensada, Orestes percorre incensando os cantos do salão, que 
estão atrás dessas pessoas. Terminado isso, a panela fica na porta de entrada do terreiro até que a brasa se acabe.

E todos continuam a cantar...

\section{Santo Antônio}

Meu Santo Antônio corre e gira sem parar / Meu Santo Antônio corre e gira sem parar / Se não fosse Santo Antônio / Ai de nós o que será / Se não fosse Santo Antônio, / Ai de nós o que será

\section{Seu Tranca-Ruas}

Lá na tronqueira eu deixei meu sentinela / Lá na tronqueira eu deixei meu sentinela / Eu deixei Seu Tranca-Ruas tomando conta da cancela / Eu deixei seu Tranca- Ruas tomando conta da cancela

Nesse momento, alguns médios recebem exus. Eles acabam "encostando" nos médios que ali estão na tentativa de entrarem na gira para fazer "arruaça" no terreiro. Muitas vezes, Joana para de cantar e espera até que o médio que esteja manifestando a presença desses exus mande-os embora. E, em seguida, reza-se o Pai Nosso novamente.

Depois disso, voltam a entoar os pontos.

\section{Ponto de Abertura}

Abrimos a nossa gira / Pedimos de coração / Para nosso pai Oxalá / Para cumprir a nossa missão / Para nosso pai Oxalá / Para cumprir a nossa missão 


\section{Saravá os Pretos-Velhos}

Pai Antônio de Aruanda é rezador / É negro velho curador / Coitado do Pai Antônio / É negro velho curador / Ele vem lá de Aruanda / A seus filhos abençoar / Pai Antônio de Aruanda é rezador / É negro velho curador / Coitado do Pai Antônio / É negro velho curador / Ele vem lá de Aruanda / A seus filhos abençoar

Mas eles são os pretos-velhos de Aruanda / Eles vem pra trabalhar / Mas eles são os pretos-velhos de Aruanda / Eles vem pra trabalhar / Com os poderes de Jesus Cristo e Iemanjá / Eles vem pra nos salvar / Com os poderes de Jesus Cristo e Iemanjá / Eles vem pra nos salvar

O céu é azul / Oi o mar também é / Oi Umbanda / O céu é azul / Oi o mar também é / Oi Umbanda / Quando Jesus, oi umbanda / Ressuscitou, oi umbanda / Sarava preto-velho, oi umbanda / Seu cruzeiro do sul, oi umbanda / Quando Jesus, oi umbanda / Ressuscitou, oi umbanda / Saravá preto-velho oi umbanda / Seu cruzeiro do sul, oi umbanda

Eu encorei meu pandeiro / Eu afinei minha viola / Eu vi meu pai no terreiro / É Pai Joaquim Mané de Angola / Oi dim, dim, dim, dim, dim, dim, / Vamos saravá Pai Joaquim

A lua lá no céu brilhou / A lua lá no céu brilhou / É Pai José de Angola que chegou / Na a sua aldeia os seus filhos abençoou / É Pai José de Angola que chegou / Na a sua aldeia os seus filhos abençoou

Pai Joaquim, cadê Pai Mané / Foi no mato apanhar guiné / Pai Joaquim, cadê Pai Mané / Foi no mato apanhar guiné / Diga a ele que quando vier / que suba a 
escada sem bater os pés / Diga a ele que quando vier / que suba a escada sem bater os pés

Com os pontos dos pretos-velhos entoados, alguns médios já começam a receber seus guias. Os médios recebem seus guias em tempos diferentes e pode ocorrer de receberem, ainda que rapidamente, um exu pagão novamente. Como há, também, médios que ainda não recebem preto-velho e continuam no local para ajudarem no descarrego.

Joana diz que, na maioria das vezes, o preto-velho é uma das últimas entidades que o médio recebe, salvo se este for seu guia de cabeça, mas os preto-velhos exigem uma determinada conduta de seus médios, como o controle do aparelho* no momento do transe e também uma boa conduta na vida particular.

O próprio consulente escolhe o médio com quem deseja tomar passe e, se quiser, pode tomar com mais de um médio. Os pretos-velhos ficam sentados em um banquinho de madeira à espera do consulente, que também se senta em outro banco posicionado a sua frente. Geralmente, um médio que ainda não recebe entidade, fica cuidando da passagem dos consulentes da assistência para dentro do congá, onde os médios estão trabalhando. Sua função é procurar organizar as pessoas pára que não fiquem paradas atrás dos médios, porque dizem que atrás deles sempre ficam as cargas negativas que acabaram de tirar da pessoa que está recebendo o passe. Também procuram orientar para que os consulentes tomem 0 passe com médios que estão iniciando esse trabalho. É também uma tentativa de aliviar a quantidade de consulentes que procuram Pai Benedito (entidade recebida por Joana). À medida que os médios vão se tornando freqüentadores assíduos do terreiro passam a ser aceitos e procurados, mas nada se compara ainda com a procura por Pai Bendito.

O momento do passe dura até que todos os consulentes sejam atendidos. Logo após, dá-se a subida dos preto-velhos e inicia-se a segunda parte da gira. Ao menos um dia na semana, geralmente quando há menos consulentes (diga-se por volta de 
15 consulentes), a gira encerra-se logo após o passe com uma prece da mãe-desanto. Mas, em outros dias, como o que inicia e o que fecha a semana de trabalho, a gira continua. São puxados, então, pontos para caboclos e baianos; eventualmente puxam ponto para marinheiros, e, raramente, puxam ponto para erês, pois dizem que eles fazem muita sujeira (gostam de beber refrigerante, mas e depois costumam agitá-lo para espirrar nos demais). Na segunda parte da gira, os médios recebem as entidades. Nesse momento, apenas os médios que estão na gira e não incorporaram podem tomar o passe assim como algum freqüentador habitual da casa. O motivo para não abrirem consulta para a assistência, deve-se ao fato de que os médios já estão cansados e para que não se estenda a hora de encerramento do trabalho.

Pode o leitor, agora, conferir os pontos cantados na segunda parte da gira:

\section{Caboclos de Oxossi}

Quem manda na mata é Oxossi / Oxossi é caçador / Oxossi é caçador / Quem manda na mata é Oxossi / Oxossi é caçador / Oxossi é caçador / Eu vi meu pai assoviar / Ele mandou chamar / É de Aruanda ééééééé / E de Aruanda aaaaaaa / Todos os caboclos de Oxossi é de Aruanda aaaaaaa

Cachoeira da mata virgem / Onde mora meu Pai Xangô / Cachoeira da mata virgem / Onde mora meu Pai Xangô / A pedra rolou lá na pedreira / A pedra rolou saravá Xangô / eeee eeeaaa / Se ele é filho de pemba / Bate a cabeça lá no congá / eeee eeeaaa / Se ele é filho de pemba / Bate a cabeça lá no congá

Seu Rompe Mato coroou / Seu Sete flechas na floresta / E nesse dia todas as matas / Foi uma noite de festas / Todos os caboclos se enfeitaram / Com as folhas de guiné / Todos os caboclos foliaram / Para chamar quem manda / É o Zé / Oi quem manda é o Zé / Oi quem manda é o Zé 
O capitão da mata me mandou chamar / Para ver o que a Jurema tem / Foi a Jurema / Foi a Jurema / E a cabocla se enfeitou de pena / Foi a Jurema / Foi a Jurema / E a cabocla se enfeitou de pena / Se meu Pai é Oxossi / Quero ver balancear / Se meu Pai é Oxossi / Quero ver balancear / Arreia, arreia / Capangueiro da Jurema / Ô Jurema má / Arreia, arreia / Capangueiro da Jurema / Ô Juremá

Vestuário de caboclo é samambaia / É samambaia, é samambaia / Descarrega caboclo / Não me atrapalha / Saia do meio da samambaia / Descarrega caboclo / Não me atrapalha / Saia do meio da samambaia

A subida Caboclo de Oxóssi / Adeus meus caboclos / Sua mata me chama / Eles vão orar, eles vão orar / Pega a pemba e solte a pemba na praia havaiano / Vem num giro só

\section{Caboclos de Ogum}

Ogum e seu cavalo corre / E a sua espada reluz / Ogum, Ogum, Meji / Sua bandeira corre o filho de Jesus / Ogum e seu cavalo corre / E a sua espada reluz / Ogum, Ogum, Meji / Sua bandeira corre os filhos de Jesus / É Ogum

Eu tenho sete espadas para me defender / Eu tenho Ogum na minha companhia / Ogum é meu pai / Ogum é meu guia / Ele vai baixar na fé de Deus e com a da Virgem Maria

\section{Baianos}

Quem tem baiano firma / Eu quero ver firmar / Quem tem baiano firma / Eu quero ver firmar / Arreia a baianada neste congá / Arreia a baianada neste congá 
Bahia é terra de dois / É terra de dois irmãos / Bahia é terra de dois / É terra de dois irmãos / Governador da Bahia é Cosme e São Damião / Governador da Bahia é Cosme e São Damião

Na Bahia tem um coco / Este coco tem dendê / Na Bahia tem um coco / Este coco tem dendê / Se a água do coco é doce também quero beber / Na Bahia tem um coco / Este coco tem dendê / Na Bahia tem um coco / Este coco tem dendê / Se a água do coco é doce, eu também quero beber

Chorou Bahia, Bahia me chamou / Chorou Bahia, Bahia me chamou / Se meu pai era baiano / Baiano também eu sou / Se for lá da Bahia na terra de meu avô

Bahia ou África / Vem cá nos ajudar / Força baiana, força mineira / Força divina, vem cá, vem cá

Baiano é mau é como surucucu / Baiano é mau é como surucucu / $E$ bate no toco ganga, baiano zanga

Estava bêbado sentado na areia / Eu vi todos os baianos com sua roupa vermelha / Estava bêbado sentado na areia / Eu vi todos os baianos com sua roupa vermelha / Lê, lê, lê re re re / Lê, lê, lê ra ra ra / Todos os baianos sentados na areia / Lê, lê, lê re re re / Lê, lê, lê ra ra ra / Todos os baianos sentados na areia

Quem tem baiano agora que eu quero ver / Pra comer sua farofa com azeite de dendê / Quem tem baiano agora que eu quero ver / Pra comer sua farofa com azeite de dendê / Bahia é bom pra quem sabe aproveitar / Quem não pode com mandinga / Não carrega patuá 
Relampejou lá nas matas e na cachoeira roncou / Oi trovejou na Bahia, baiano velho chegou / Oi quem mandou na Aruanda saiu e viajou / Oi quem mandou na Aruanda sou eu, sim senhor / Oi serenou lá nas matas ou na cachoeira roncou / Oi trovejou na Bahia, sou eu sim senhor / Oi a baianada chegou, baiano velho chegou / Oi quem manda na Aruanda

Na Bahia tem, vou mandar buscar / Lampião de vidro pra clarear / Sua dona vou mandar buscar

Se quiser me ver / Sobe em cima de um barranco, oi Zé / Se quiser me ver/ Sobe em cima de um barranco, oi Zé / Mas o homem é / Tranca Rua de "embaié" / Mas o homem é / Tranca Rua de "embaié"

O baiano vai embora ô lindaruê, ô lindaruá / Ê, ê, ê, ô lindaruê, ô lindaruá

\section{Boiadeiros}

Joguei a minha corda / Corda de laçar meu boi / Joguei a minha corda / Eu não sei pra onde foi / Seu Boiadeiro / Seu Boiadeiro sou eu / Quem vem lá seu Boiadeiro / Quem vem lá seu Boiadeiro sou eu / Joguei a minha corda / Corda de laçar meu boi / Joguei a minha corda / Eu não sei pra onde foi / Seu Boiadeiro / Seu Boiadeiro sou eu / Quem vem lá seu Boiadeiro / Quem vem lá seu Boiadeiro sou eu

A seguir, estão os pontos cantados no trabalho com a esquerda. Relembro o leitor que o trabalho com a esquerda ocorre somente depois de encerrado o trabalho com a direita. Nesse momento, são cantados apenas um ou dois pontos e logo se inicia o trabalho. Seguem os pontos: 


\section{$\underline{\text { Exu }}$}

Exu no terreiro é o rei / Na encruza ele é doutor / Exu vence a demanda / Exu é vencedor / Exu no terreiro é o rei / Na encruza ele é doutor / Exu vence a demanda / Exu é vencedor

Oi que pisa no toco, pisa no galho / Exu não bambeia, se não eu caio oi ganga / Êeee, oi que pisa no toco / De um galho só / Êeee, oi que pisa no toco / De um galho só

O sino da igrejinha faz dilim dim dom / Deu meia noite o galo já cantou / Seu Tranca Rua que é o dono da gira / Oi corre a gira que Exu mandou / Seu Tranca Rua que é o dono da gira / Oi corre a gira que Ogum mandou

\section{Pomba Gira}

Vinha caminhando a pé / Para ver se encontrava pomba-gira cigana de fé / Ela parou e leu a minha mão / E me disse a mais pura verdade / Eu só queria saber onde andava pomba-gira cigana de fé

Os médios ficam de costas para o pejí, voltados para a rua. Retiram as demais guias que estavam no pescoço e ficam apenas com as guias vermelhas e pretas que simbolizam as cores da esquerda; alguns médios também trocam a camiseta branca por camisetas vermelhas ou pretas. 


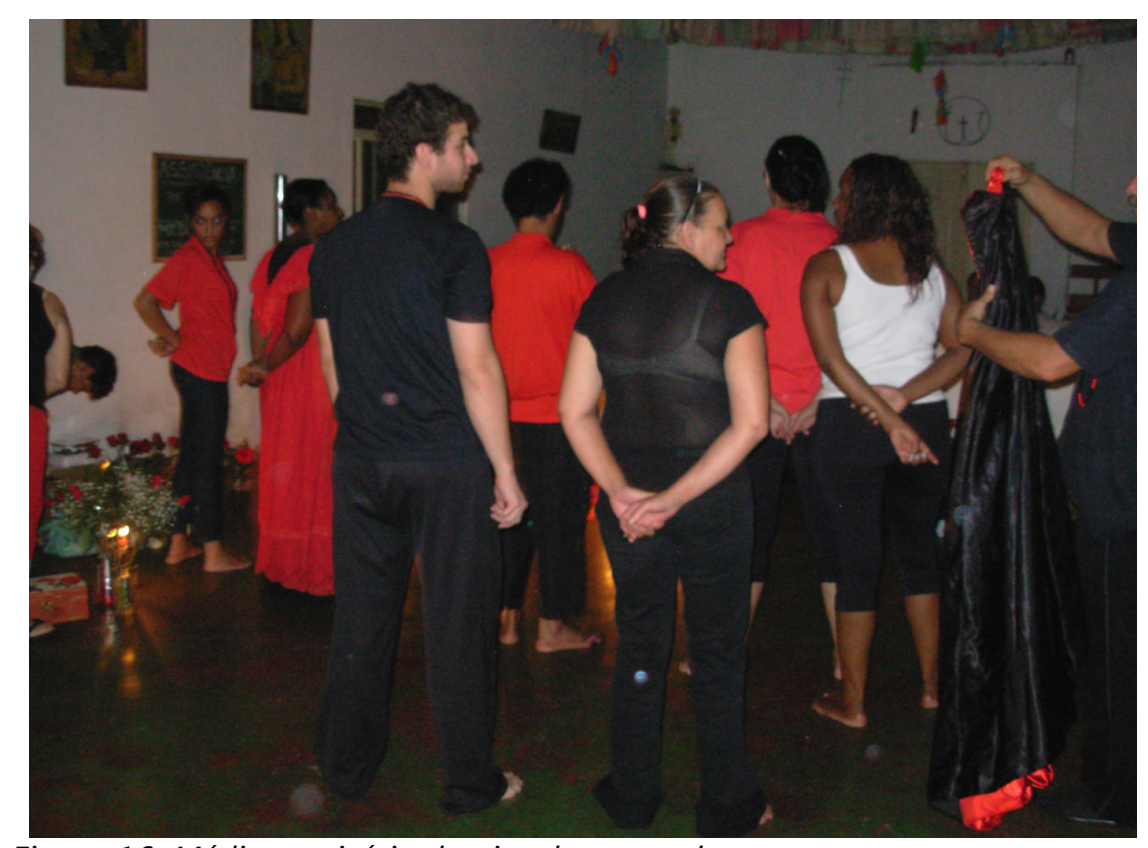

Figura 16: Médios no início da gira de esquerda.

As luzes do terreiro ficam apagadas e a iluminação vem das velas acesas espalhadas pelo chão e pelo pejí. Os atendimentos são feitos no chão. Primeiro, os médios recebem seus exus e, depois, as pombas-gira. Nesse terreiro, apenas as mulheres e homossexuais recebem as pombas-gira. Os homens recebem apenas os exus, mas as mulheres também podem recebê-los. Quando as pombas-gira chegam, sempre fica um exu para tomar conta do trabalho, ou seja, das pombas-gira (geralmente quem faz isso é o exu da Joana ou do Orestes).

Quando solicitei para Seu Sete (exu de Joana) que gostaria de tirar uma foto, ele me disse:

“Exu Sete: foto minha não! Não gosto dessas coisa.

Pesquisadora: Por quê?

Exu sete: Eu não gosto disso aí.

Pesquisadora: Você conhece?

Exu sete: Não, isso não é do meu tempo. Com exu não é pra fica com essas coisa.

Pesquisadora: Mas as pombas-gira deixaram?!

Exu Sete: É que essas mulher são tudo assanhada."

(Depoimento - Exu Sete 06/03/2008) 


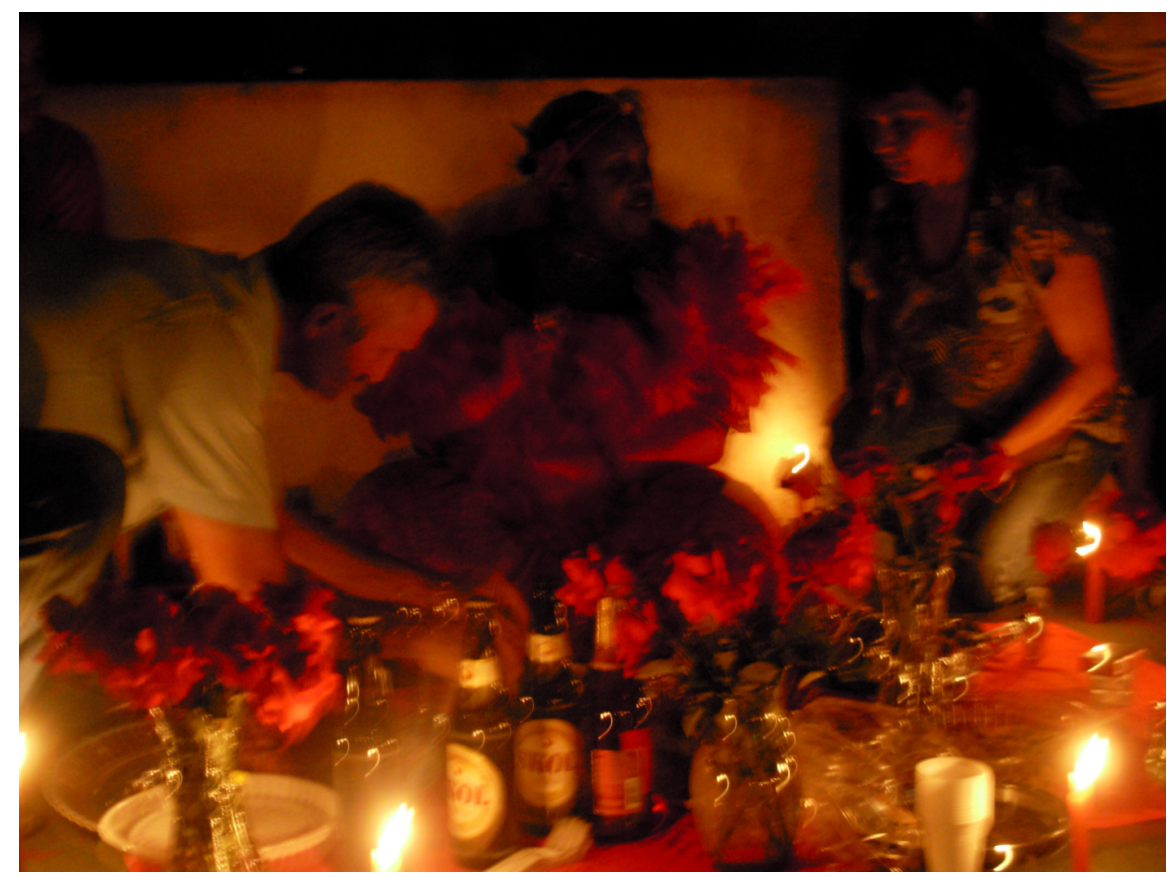

Figura 17: Foto de uma Maria Padilha (pomba-gira) em festa de esquerda.

Não poderia deixar de mencionar, nesse item, o trabalho de desenvolvimento* dos médios que se iniciam na casa. Isso se dá durante as referidas giras, pois não existe gira especial para o desenvolvimento dos médios, como também não há a necessidade de uma formação teórica pra tal, como ocorre na maioria das outras casas que sofrem a influência do kardecismo. Contudo, quando há algum médio novo no congá, a mãe de santo fica sempre atenta a ele e, quando esta percebe alguma manifestação espiritual, pede sempre para que os médios mais experientes dêem as mãos, fazendo uma roda ao redor do médio em desenvolvimento. Segundo Joana, esse cuidado é necessário porque a entidade pode vir com muita força e jogar o médio no chão, uma vez que esse último ainda não tem controle sobre o seu aparelho. Assim, qualquer pessoa que se disponibiliza a "entrar na linha*" para receber suas entidades, pode fazê-lo quase sem nenhuma restrição. O único dever é pedir a permissão de Joana antes de iniciar a gira.

Segundo Joana, que dá pouquíssimas orientações a seus médios, são os próprios guias espirituais de cada um que irão ensiná-los a trabalhar na mediunidade. Ela diz: 
“... comigo foi assim, ninguém veio me ensiná, modo de que, a pessoa tem de que aprende sozinha!"

(Depoimento Joana - 20/11/2005)

Caso um médio não se adapte aos padrões da casa, Joana pede ajuda para as entidades mentoras afastarem sua presença dali. Foi possível acompanhar o caso de um médio vindo de outro terreiro que falava muitos palavrões ao incorporar entidades de esquerda. Joana repreendia a entidade do médio, dizendo que ali não era lugar para falar aquelas coisas e, enquanto o médio permaneceu trabalhando na casa, Joana dizia aos médios mais próximos que estava pedindo para que os guias da casa decidissem sua permanência (caso, realmente, não fosse local para ele trabalhar).

Disse ela:

“...quem sou eu pra decidi se ele vai trabalha ou não, isso é coisa das entidade."

(Depoimento Joana-10/10/2006)

\subsubsection{Giras fora do terreiro}

A praia

As giras externas, em sua maioria, acontecem esporadicamente, dependendo da necessidade de se fazer um banho de cachoeira, uma oferenda na praia ou na encruza. Geralmente, essas giras são feitas a pedido das entidades que se identificam com os locais descritos, como exu e pomba-gira na encruza, iemanjá e marinheiro na praia e caboclos na mata ou cachoeira. 
A única gira externa determinada pela casa é a ida à praia, que ocorre no início do ano, perto do mês de Iemanjá (comemorado por esse terreiro no dia 02 de fevereiro, enquanto alguns comemoram no dia 08 de dezembro). O local escolhido é a cidade de Praia Grande, no litoral norte de São Paulo, na praia de Iemanjá, onde se encontra uma estátua do orixá.

Joana diz não gostar de ir à praia por volta do dia que se comemora Iemanjá, pois diz que a praia fica cheia de terreiros que vão fazer suas homenagens e isso atrai muitos curiosos ao local e esses sempre os procuram para receber passe.

O leitor deve estar pensando: mas o que há de errado nisso? Não prezam pela caridade?

Sim, Joana explica que trabalhar com entidades fora do terreiro, em céu aberto, exige do médio um domínio muito grande de suas faculdades mediúnicas. Segundo ela, as entidades quando são incorporadas fora da casa, chegam com muito mais força, é como se viessem em seu estado latente e isso cansa muito o médio. Fato é que, para as giras externas, Joana só leva seus médios mais experientes, o que não significa ter mais anos de casa e sim um trabalho sério e compromissado na mediunidade, o que para ela significa assiduidade nas giras. Também há o fato de que quando é feito um trabalho de descarrego na praia, aonde os médios vão para descarregar suas cargas negativas, é importante que esses retornem ao terreiro "limpos". A limpeza a que Joana se refere são das cargas negativas que os médios atraem para si no momento do passe, cargas essas, vindas dos consulentes. Quando são muito fortes, o médio só se livra delas nas águas do mar. Assim, não adianta benzer por lá e voltar carregado novamente.

Durante meu percurso na casa, pude acompanhar uma gira na praia que ocorreu no dia 24 de maio de 2006, um sábado. A viagem vinha sendo organizada desde o começo do ano, mas por motivos financeiros dos médios a mesma só ocorreu na data explicitada acima. 
A ida a praia é sempre uma festa! Apesar de cansativa, porque a viagem de Jardinópolis até Praia Grande é feita em quase sete horas, todos se alegram e não querem perder o passeio, mesmo que esse seja a trabalho.

Sendo assim, um grupo de médios, determinado por Joana, saiu do terreiro, em Jardinópolis, no dia 24 às 2 horas da manhã. Ressalto que no dia anterior, sexta-feira, o terreiro executou seu trabalho normalmente, encerrando suas atividades 1 h e 15 minutos, já do dia 24.

O grupo contou com a mãe-de-santo Joana, com Meire (sua irmã e mãe pequena, a qual não estava trabalhando na mediunidade devido aos 7 meses de gravidez), Orestes (médio e marido de Meire) e mais seis médios. O grupo seguiu em dois carros rumo a Praia Grande.

A viagem estava programada para o dia 21 de abril, mas a mãe-de-santo, Joana, não havia conseguido um segundo carro para levar dois médios. Segundo ela:

\section{“....se não dá pra ir um, então, não vai nenhum!"}

(Depoimento Joana - 15/05/2005)

Assim que chegaram à praia, procuraram o local onde existe uma grande imagem de Iemanjá e, onde se fazem os trabalhos à noite. Acenderam suas velas para agradecer a viagem realizada. Depois, entraram em contato com um médio que estava hospedado com sua esposa, na casa de parentes naquela cidade. Nesta casa, todo o grupo almoçou e descansou até às 16 horas e 30 minutos. Seguiram, depois, para o local já programado para o trabalho.

Às 20 horas chegaram outros dois médios que estavam hospedados em outra cidade.

Por volta das por volta das 21 horas, todos acenderam velas aos pés da imagem de Iemanjá antes de começar o trabalho. Neste local, havia umas três barraquinhas com mulheres vestidas de branco, jogando cartas. 
O grupo de Joana desceu em direção ao mar e ali arrumou o local. Foram feitos três buracos no chão, dos quais participei ativamente em suas aberturas, para colocarem as velas porque ventava muito, No primeiro buraco colocaram 7 velas brancas, 7 azuis e 7 vermelhas, os outros dois colocaram 7 vermelhas em cada.

As pessoas que passeavam pela praia iam se aproximando e, algumas, perguntavam se podiam assistir. Assim foi se formando uma roda ao redor dos médios.

O trabalho iniciou com Joana rezando o Pai Nosso e depois puxando os pontos de Iemanjá, pretos-velhos, Ogum, marinheiro, baiano e exu. Em todos eles, com exceção do ponto de Iemanjá, os médios receberam os seus guias e foram os baianos que deram os passes nas pessoas que estavam ao redor. Algumas pessoas permaneceram ali mais algum tempo e depois foram embora. Apesar de Joana discursar contra os atendimentos do público local, ela acabou acolhendo a todos. Tudo isso durou cerca de 1 hora.

Depois, os médios e a mãe-de-santo foram para o mar para "fazer a cabeça*". Lá, eles entram na água até a altura das canelas e a mãe-de-santo reza e derrama vinho branco, depois, cerveja preta sobre a cabeça de cada um dos médios, que pulam as sete ondas e ali lavam suas guias. Dois dos médios receberam seus guias de cabeça.

Terminado o ritual, eles retornaram à praia, recolheram os charutos usados para serem levados novamente ao centro. Caso os charutos ficassem ali seriam varridos pelos garis e isso, segundo Meire, não poderia acontecer. Porém, a não me explicou o porquê.

Assim, encerrado o trabalho, perto das 23 horas, todo o grupo se reuniu e despediu-se. O grupo de Joana descansou até as 5 horas da manhã, quando seguiram viagem para Jardinópolis. 


\section{$\underline{\text { A encruza }}$}

A encruza nada mais é que o ponto de encontro de duas ou mais ruas, sendo a esquina o local ideal para a realização dos despachos*.

Como já foi mencionado acima, o terreiro costuma fazer gira nesses locais quando há alguma demanda forte contra o terreiro, algum médio ou algum consulente.

A gira que tive oportunidade de participar foi para resolver as demandas que um outro centro de umbanda estava recebendo e não conseguia resolver o problema, então foram pedir para que Joana os ajudasse. Durante várias semanas, alguns médios e o pai de santo, do terreiro referido acima, freqüentaram as giras regulares no terreiro da Joana até que se marcou o dia para fazer o trabalho na encruza.

Estávamos no mês de fevereiro de 2007 e chovia bastante naqueles dias. Esperava-se por um dia em que o tempo melhorasse e fosse possível conseguir um carro grande, tipo caminhonete, para levar todos os médios e para que não ficássemos atolados aonde a gira aconteceria.

Assim, com as graças de São Pedro e do pai-de-santo ávido pela realização do trabalho, conseguimos uma noite sem chuva e uma caminhonete F-1000 que nos levou para a encruza.

Saímos do terreiro, por volta das 23 horas do terreiro, depois de carregar a caminhonete com as cervejas, velas, pólvoras e comidas destinadas aos exus e pombas-gira.

Um dos filhos de Joana, que ajudou a carregar o carro, ao ver tudo pronto, as oferendas e médios empilhados, começou a rir e a brincar com todos, chamando-os de macumbeiros.

Cinco médios foram sentados na frente e os outros nove foram na caçamba, equilibrando-se entre as oferendas. No caminho, todos se divertiam contando piadas 
e histórias de encruza, entre a falta de espaço e os pingos de barro que vinham das poças por onde passávamos.

Depois de uns 20 minutos, encontramos velas vermelhas, ainda acesas, formando uma estrela de Davi, numa das encruzas do caminho. Joana saudou o local e pediu para que a caminhonete continuasse procurando um lugar para pararmos, porque aquele já havia sido utilizado por um outro terreiro.

Ao encontrarmos um local apropriado, paramos e começamos a descarregar a caminhonete e a acender as velas para clarear o local, até então, iluminado pelo farol do veículo.

Joana rezou e pediu licença para começar a gira. Os médios, postos em círculos, foram recebendo seus exus e pombas-gira. Na rua, ou melhor, na encruza, as entidades falaram alguns palavrões, mas não foram repreendidos pela mãe-de-santo, como é de seu costume.

Chegando ao término do trabalho, Seu Sete ordenou que fosse queimada a pólvora a fim de limpar o ambiente e finalizar o trabalho. Assim, depois de duas horas, voltamos todos ao centro.

É preciso dizer que há também os trabalhos realizados na mata e na cachoeira, mas numa quantidade muito menor se comparados com as encruzas.

\subsubsection{Giras festivas}

Durante todo o ano, em quase todos os meses há giras festivas para algumas entidades. A escolha da entidade a ser festejada geralmente é feita por Pai Benedito, o preto-velho, ou por Seu Sete, o exu. Outras datas festejadas são as já convencionadas em toda a umbanda, as quais estão relacionadas com o dia comemorativo das entidades, como o 13 de maio que é o Dia da Abolição dos 
Escravos e comemora-se o dia dos pretos-velhos e também 27 de Setembro quando se comemora Cosme e Damião.

As festas são realizadas nas giras de costume (exceto os ciganos que são trabalhados apenas aos sábados) onde apenas realiza-se o trato* da entidade. Essas entidades são reverenciadas por agradecimento e/ou também para pedir a sua proteção para a casa.

Nos dias de festa, Orestes é o responsável por comunicar-se com os médios via e-mail. É ele quem sempre envia as mensagens com uma semana de antecedência avisando sobre a festa e o trato que os médios devem levar. Cada entidade tem o seu trato, por exemplo:

- Festa de Pretos-Velho: rosas brancas, arruda, guiné, alecrim, café em grão, vara de café, folhagem de café, café amargo, fumo, bolo de fubá, farofa de rapadura, feijoada, couve refogada, vinho tinto suave e vela branca.

- Festa de Xangô: rabada com quiabo, cerveja preta, frutas (exceto abacaxi, coco, abacate, caqui, laranja, mexerica, tangerina, banana), vela branca, vela marrom, folhagens e rosa branca.

- Festa de Baiano: farofa com carne seca, moranga com carne seca, bobó de camarão, coco seco com água, coco verde com água, cerveja, pinga, batida de coco, vela branca, vela amarela, vela vermelha, folhagens e rosa branca.

- Festa de Ogum: inhame perfurado com 21 palitos de dente, arroz com camarão, cerveja, pinga, vela branca, vela vermelha, folhagens e rosa branca.

- Festa de Iansã: canjica branca sem açúcar, mel, cerveja, vinho branco,vela branca, vela rosa, vela amarela, rosa branca e planta copo de leite. 
- Festa de Iemanjá / Linha d'água: peixe assado na folha de bananeira, peixe no molho, arroz com camarão, cerveja, vinho branco, champagne branca, rosa branca, planta copo de leite, vela branca, vela azul clara, vela rosa e vela amarela.

- Festa de Oxossi: frutas (exceto coco, banana, abacate, laranja, tangerina, abacaxi, mexeria, caqui), cerveja, folhagens, rosa branca, vela branca e vela verde.

- Festa de Boiadeiro: arroz carreteiro, feijão tropeiro, carne assada no espeto, cerveja, pinga, vela branca, vela vermelha e vela amarela.

- Festa de ciganos: arroz com carne seca, arroz com camarão, carneiro assado (pernil), kibe cru, manjar com bastante cereja (exceto manjar de coco), cereja em calda, doce de leite, mel, frutas (maça, pêra, uva, melão, pêssego, cereja, morango, nectarina, ameixa), cerveja, soda limonada, guaraná, whisky, vodka, licor de curaçau blue, licor de cassis, licor de chocolate, amarula, champagne rose, cigarro longo branco, taça de cristal, moedas, rosa vermelha, rosa branca, rosa amarela, incenso de palito, vela laranja, vela branca e vela azul claro.

- Festa de Cosme e Damião: bolo enfeitado (exceto de chocolate), guaraná, pipoca doce, bala mastigável, pirulito, doces, vela azul clara, vela rosa e brinquedos que não possam ferir as crianças.

No terreiro de Pai Benedito, a festa de Cosme e Damião se destaca das demais. Mobiliza todos os médios e uma grande parte dos freqüentadores. Os preparativos começam com dois meses de antecedência. Todos os médios e também os freqüentadores são convidados a contribuírem com adereços (bandeirinhas coloridas e folhagens), doces e refrigerantes. Para essa comemoração todas as imagens da casa são lavadas e a toalha branca do peji é trocada, (está é doada todos os anos por uma senhora que a confecciona e borda). São recolhidas as bandeirinhas que ficaram 
expostas desde a última festa de Cosme e Damião e serão trocadas pelas novas, que enfeitarão o teto do terreiro por mais um ano.

Joana arrecada muitos doces para essa festa, e recebe muitas crianças vindas da vizinhança, nesse dia.

A festa de Cosme e Damião é famosa nesse terreiro desde a época de D. Chiquinha e, durante os preparativos, é possível perceber a preocupação de Joana para que tudo ocorra como nos tempos em que sua mãe era viva.

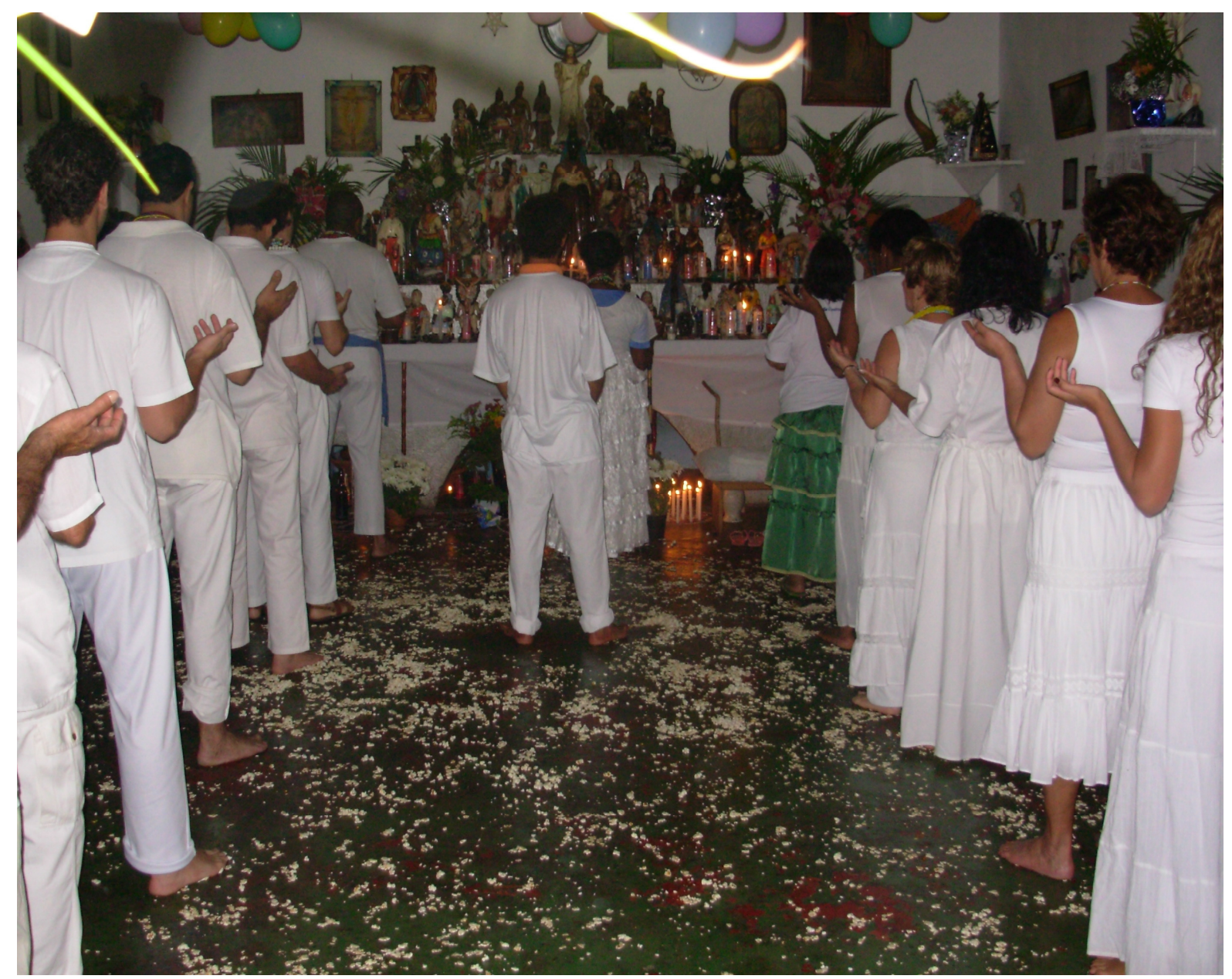

Figura 18: Gira festiva de Cosme e Damião. 
Com o chão coberto de pipoca, a gira se inicia como as demais. No entanto, comparecem todos os médios que freqüentam com assiduidade e até os que aparecem eventualmente. Eles colocam suas melhores roupas, cantam os pontos de abertura, e tratam das entidades; Joazinhos, Mariazinhas e Pedrinhos que "descem" ao congá para brincar, beber e comer doces. No momento da comilança, as crianças da assistência podem participar e muitos adulto levam presentes para as entidades e são benzidos por elas.

Os cosmes fazem muita bagunça entre eles e com as pessoas que ali estão. Eles jogam balas e doces para o alto e fazem chuva de refrigerante. Não há como ficar de fora.

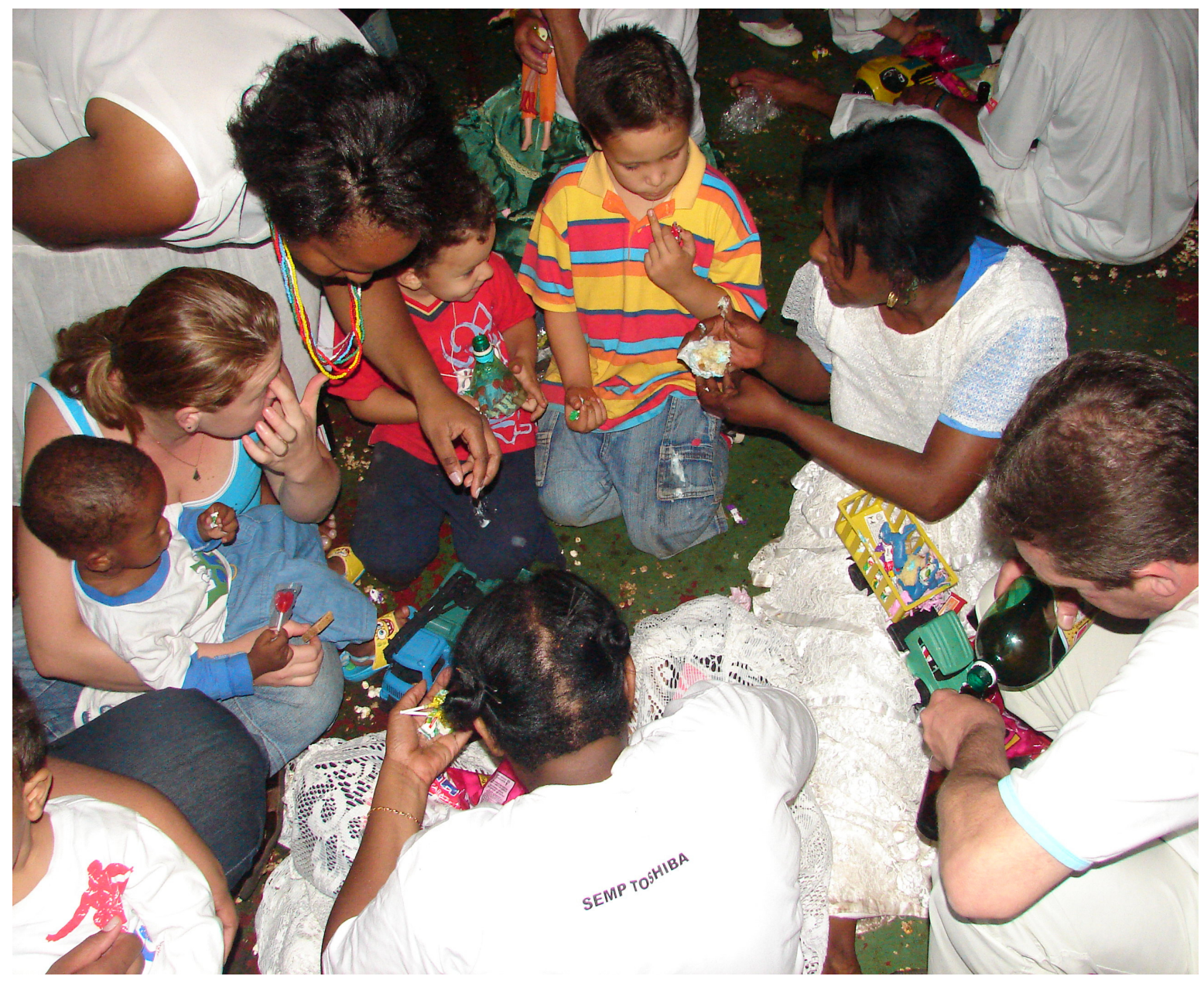

Figura 19: Consulentes em interação com os médios durante a Festa de Cosme e Damião. 
Faltar a uma festa de Cosme é como fazer desfeita à própria casa de umbanda. Parece ser a única coisa que Joana não gosta que seus "filhos" façam. Faltar a essa festa é ganhar uma cara de incompreensão da mãe-de-santo, seja lá qual for o motivo.

Fato que fui entender, tempos depois, quando contei à Joana um sonho que tive com sua mãe. Nele, D. Chiquinha estava na porta de uma casa cor-de-rosa! Logo, deixo ao bom entendedor que tire suas conclusões já que, nesse caso, me foi pedido para não dar a minha.

Assim, andar pelo terreiro de Joana é certeza de encontrar sempre crianças. Ora são os netos e sobrinhos, ora crianças trazidas pelos pais para serem benzidas, criança na fila dos médios (como o caso relatado anteriormente), crianças acompanhando o pai no atabaque, crianças que vão por conta própria para serem benzidas ou crianças da vizinhança que entram a procura de outras crianças para brincarem. Em todos os momentos elas são sempre bem recebidas.

Durante a pesquisa acompanhei o nascimento de um neto de Joana, o Gabriel (filho de Gisele, única filha de Joana) e de um sobrinho, o Matheus (filho de Meire, a mãe pequena), cujas datas de nascimento diferem por alguns dias. Neto e sobrinho de Joana parecem ser o retrato vivo de Cosme e Damião, pois os dois meninos estão juntos a brincar pelo terreiro e não se separam nem para tomar passe.

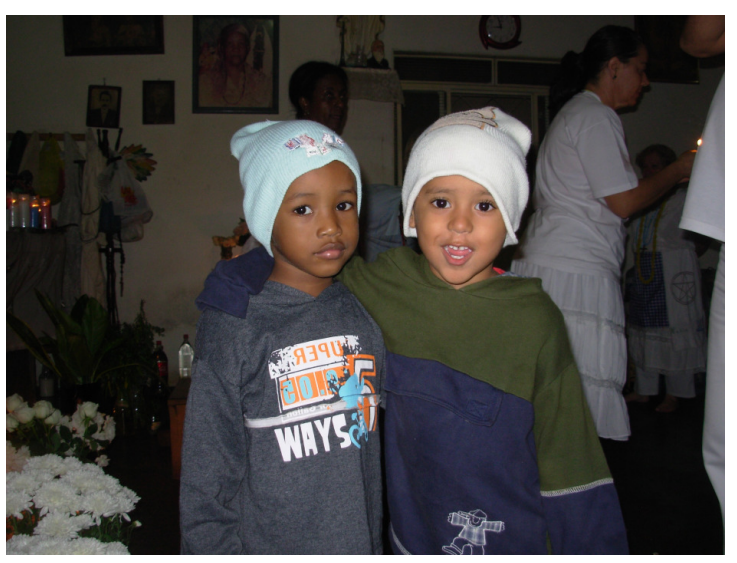

Figura 20: Mateus e Gabriel.

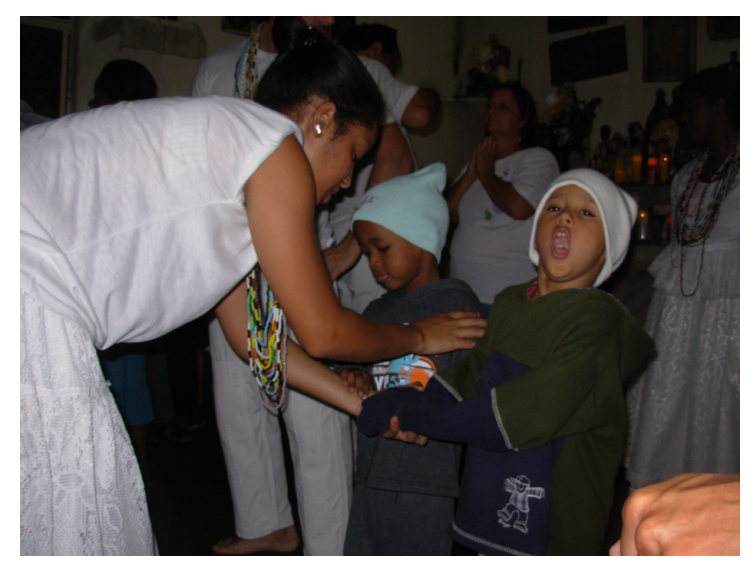

Figura 21: Mateus e Gabriel tomando passe. 
Segundo Joana, a linha de Cosme e Damião é a mais forte de todas as linhas. Não há o que se peça para ela, que não se consiga! Como ela mesma disse:

“...você nunca ouviu o ditado: com criança ninguém pode!?"

(Depoimento Joana - 13/10/2008)

Assim, depois de tratadas as entidades na festa de Cosme e Damião, todos os doces são levados ao centro do congá para que a assistência venha pegá-los. Mas antes, Pai Benedito vai abençoá-los. Ele caminha, quase dançando, ao redor dos doces, ao som dos atabaques, e todos fazem silêncio para ver, não sei se as bênçãos de Pai Benedito ou o trabalho incansável daquela mãe-de-santo, que perpetua essa tradição desde os tempos de sua mãe.

Certamente, a festa de Cosme e Damião é a mais alegre da casa. Contudo, uma das mais luxuosas é a festa dos ciganos, que acontece sob o comando de Meire, geralmente aos sábados, por ser este o dia reservado a eles.

Segundo a tradição, cigano é o povo do dinheiro e em sua festa é preciso ter fartura, pois, se você economizar no trato, corre o risco de despertar a ira desse povo que, conforme dizem, costuma ser vingativo. 


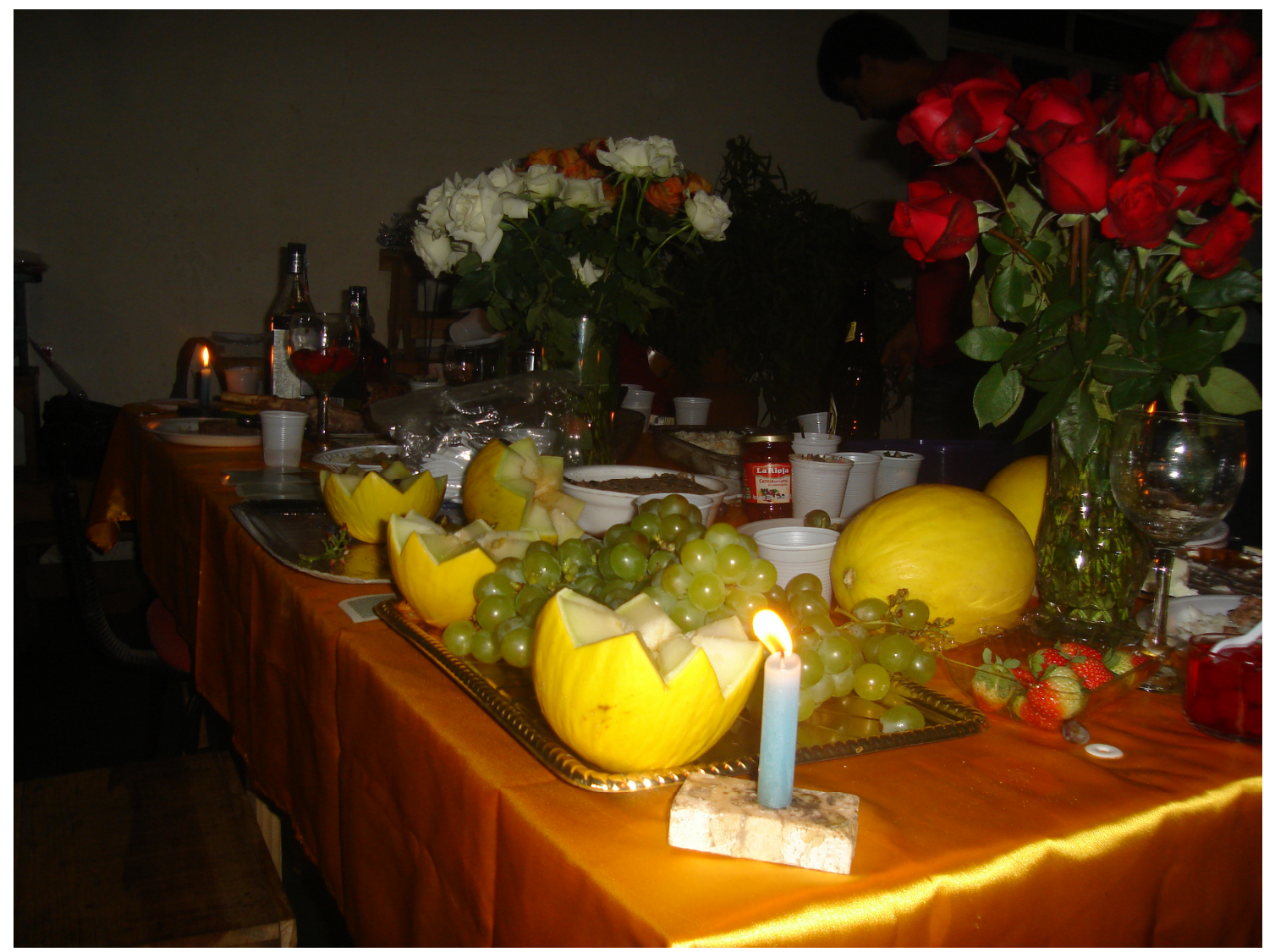

Figura 22: Mesa posta para festa de ciganos.

Joana conta que um freqüentador da casa havia prometido realizar uma festa para os ciganos em agradecimento a um pedido realizado. Como esta pessoa não a fez como havia prometido e, no dia seguinte, bateu seu carro.

Então, Meire procura arrumar tudo de maneira a contentar o chamado povo do oriente. Uma mesa grande, com toalha dourada e cerca de doze lugares é posta no conga, para que a festa aconteça ao seu redor. Apenas os médios e alguns freqüentadores da casa são convidados. Sobre a mesa moedas, cartas, velas, bebidas, comidas e flores.

Diferentemente das outras entidades, os ciganos são as únicas que cobram para "atender" em dia de festa. Antes do consulente fazer a consulta, ele precisa deixar um dinheiro em um pratinho que fica próximo da cigana da Meire (Jacira), a responsável pelas arrecadações. 


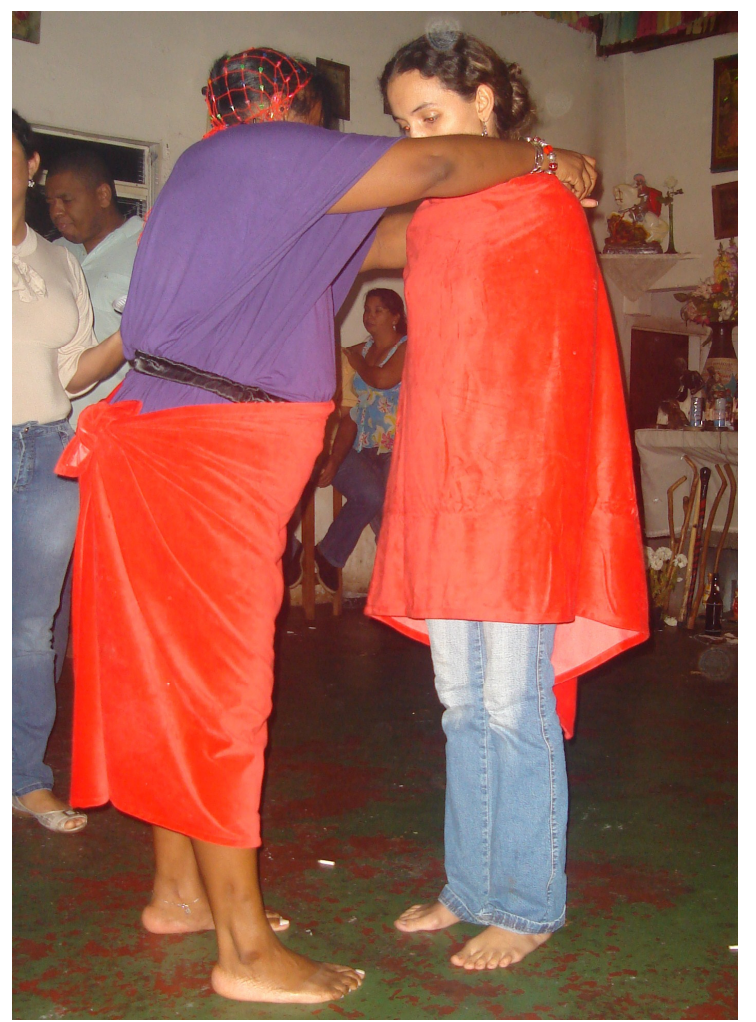

Figura 23: Cigana em atendimento durante festa.

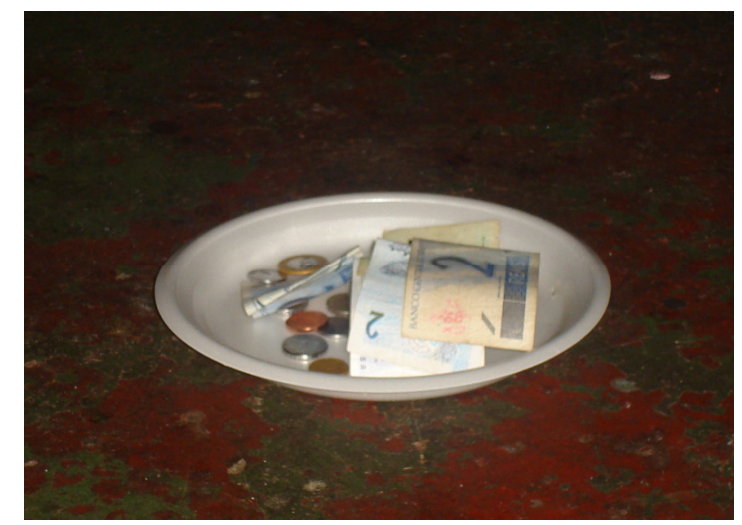

Figura 24: Pagamento para os ciganos.

Os atendimentos podem acontecer com as entidades e consulentes sentados, lado a lado, na mesa ou como mostra a figura acima.

Os ciganos falam com um sotaque castelhano e suas mensagens são sempre para predizer o futuro. Trazem implícito, em suas falas, um sentimento de que o homem não pode se contentar com qualquer coisa que a vida lhe oferece, pois é preciso sempre acreditar e buscar maiores conquistas.

Outra festa importante, não apenas no terreiro de Pai Benedito, mas para toda a comunidade umbandista, é o 13 de maio. Nesta data em que se comemora oficialmente a abolição da escravatura, os umbandistas também comemoram o dia do preto-velho. Nesse dia, preto-velho não faz suas consultas, pois eles descem à terra apenas para comemorarem; curtem o cachimbo, comem feijoada e bolo de fubá, alguns tomam café amargo e outros vinho suave. A festa é humilde, como a própria entidade. 


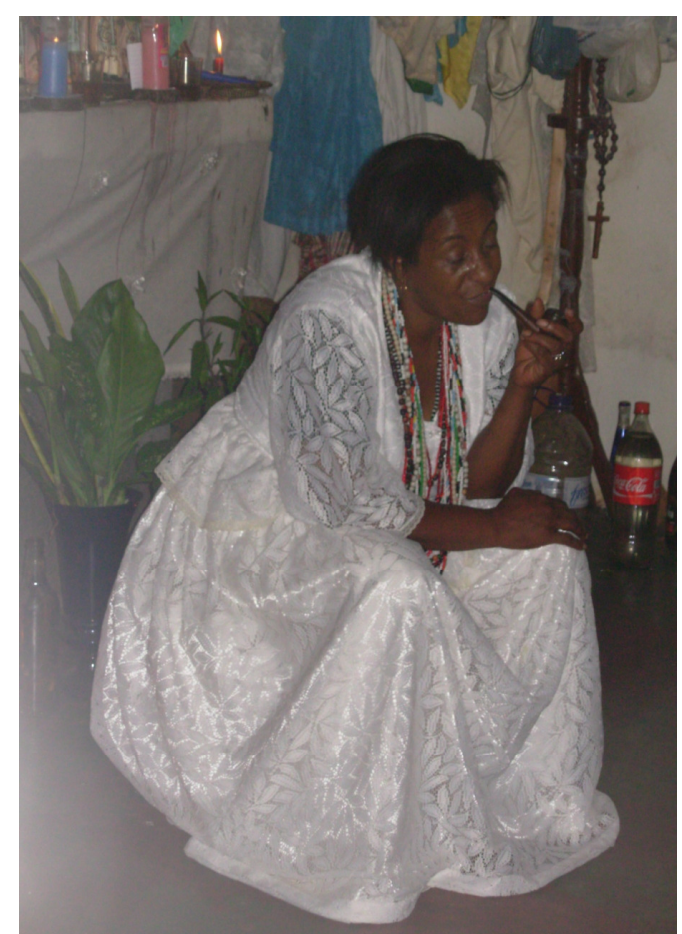

Figura 25: Pai Benedito e seu cachimbo.

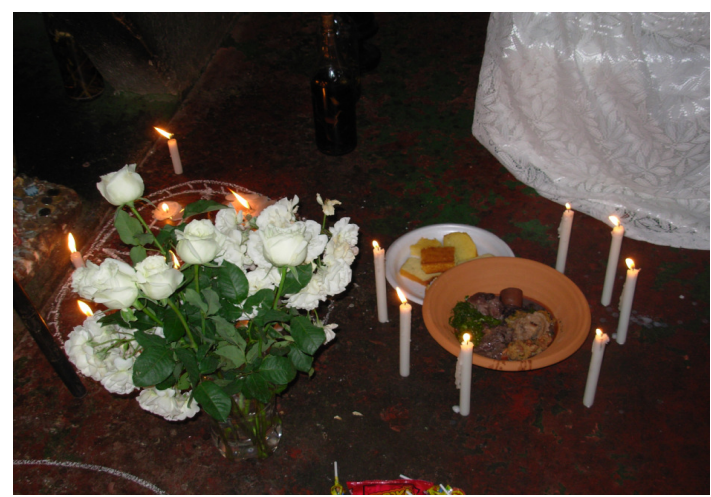

Figura 26: Oferendas para preto-velho.

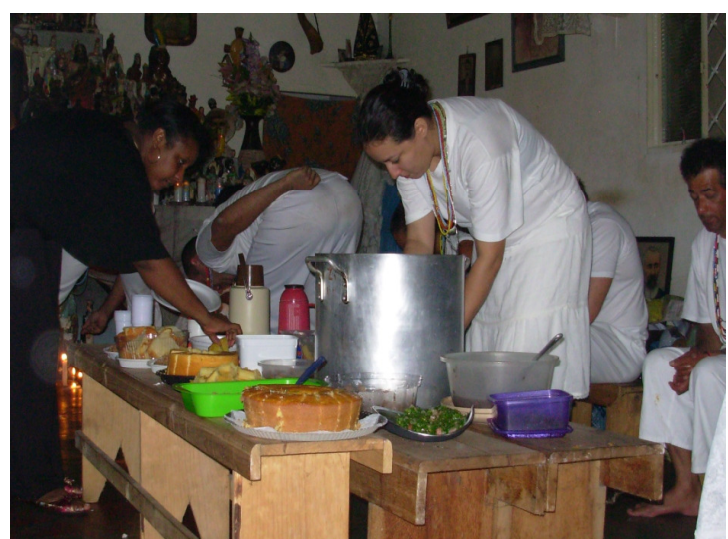

Figura 27: Mesa posta para pretos-velhos

\section{4 - OS FIÉIS}

A população que freqüenta as giras do terreiro é, em sua grande maioria, pessoas que vivem do trabalho braçal, do corte de cana ou de serviços domésticos. Mas há também consulentes com maior status social, tais como policiais, políticos e empresários, os quais procuram horários distintos das giras oficiais.

$\mathrm{Na}$ listagem de consulentes não oficiais, podemos encontrar muitos evangélicos que procuram a proteção e as orientações de Pai Benedito, ocorrendo até alguns casos de "irmãos" que se encontraram no terreiro e ambos pediram sigilo um para o outro. 
Quanto aos médios da casa, em geral, são pessoas humildes. A maioria não possui curso superior e executam trabalhos braçais.

O terreiro vive de contribuições. A maior parte das despesas são pagas pela própria Joana, o restante é dividido entre os médios que podem contribuir com a mensalidade de vinte reais. Há cerca de dois anos começou a passar uma cesta arrecadando contribuições entre os consulentes, no momento da gira. A assistência pode contribuir também com velas ou material de limpeza.

Todos os atendimentos são feitos sem custos aos consulentes, apenas em caso de ser feito algum trabalho*. A pessoa pode comprar os materiais a serem utilizados ou, se preferir, pode pagar pelo valor aproximado do que será usado, o que nunca gera uma despesa muito alta, pois em geral, são utilizados bebidas, velas, pólvora, cigarros e charutos.

Já presenciei várias vezes, a mãe de santo deixar o consulente pagar aos poucos o valor do material gasto. De acordo com Joana, ela diz que não se pode cobrar para benzer ou prestar atendimentos espirituais aos que ali chegam, pois sua mediunidade foi um dom dado por Deus, para que ela prestasse caridade aos necessitados. Ela cobra apenas o material porque as próprias pessoas preferem que ela os compre, por não terem tempo, ou por não saberem fazê-lo.

Quanto às carências espirituais mais encontradas na casa são os pedidos de ajuda para resolver problemas de saúde ou trabalho, e quase sempre essas queixas são direcionadas para Pai Benedito resolver ou outros pretos-velhos da casa. Quando se trata de alguma cobrança, casos com a lei e, sendo o consulente freqüentador do local, consulta-se com os exus para resolver. Se o consulente for novo na casa, pode consultar-se com os pretos-velhos para estes problemas também. Mas, se o que se quer é curar dores amorosas, então, é preciso recorrer à Maria Padilha - pomba-gira recebida por Meire, irmã de Joana.

Vale dizer que, todos que ali chegam à procura de atendimento espiritual são tratados da mesma forma, sem distinção de credo, cor ou classe social e, na maioria 
das vezes, saem com receitas de banhos ou chás para continuarem o tratamento em casa.

\section{5 - UTILIZAÇAO DE PLANTAS}

As plantas estão presentes nas preparações de amacis, que são os banhos de defesa, de limpeza/descarrego, de purificação, nas bebidas e remédios, na defumação, nos cachimbos, charutos e cigarros.

Para que essa comunidade esteja sempre amparada pelas entidades é preciso que todos os integrantes do trabalho da casa cumpram não apenas as obrigações do trabalho com a mediunidade, mas também com o ritual que é feito antes de iniciar o trabalho. Exemplifico, mostrando ao leitor, algumas orientações da casa que foram divulgadas por um de seus médios em 2005 (anexo B ).

Às segundas-feiras, dia de preto-velho, os médios deverão fazer banho com rosa branca, arruda e guiné ou apenas pétalas de rosas brancas, antes de irem trabalhar nas giras. Os banhos são preparados em canecas com água quente, onde se jogam os ingredientes e espera-se até que a água amorne. Depois de terminar o banho diário, o médio joga esse "banho espiritual" dos ombros para baixo. Nunca na cabeça.

Às quartas-feiras, reservada aos caboclos, o banho deverá conter arruda, alecrim e guiné ou apenas folhas de pitanga.

Às sextas-feiras, os banhos são para os baianos e eles deverão ser feito com 7 ervas: Espada de São Jorge (uma folha cortada em 7 pedaços), 3 dentes de alho, 3 pedaços de fumo, 3 pedaços de coco seco, 3 folhas de arruda, 3 folhas de guiné, 3 folhas de alecrim e 3 folhas de samambaia.

Todo médio deverá fazer e tomar o banho de descarrego antes de ir trabalhar no centro. Esse banho poderá conter diversos ingredientes. Pode ser usado apenas 
sal grosso, ou apenas hortelã ou ser indicado por alguma entidade de acordo com as necessidades do médio.

Mas não só os médios precisam dessa "limpeza", o próprio terreiro também. Para isso são feitas as defumações.

A defumação feita no dia de trabalho carrega incenso, alfazema, benjoim, folha de louro, cravo, noz moscada, canela em pau, breu, mirra e açúcar cristal. Outro tipo de defumação pode levar arruda, alecrim, guiné, folha de laranjeira, folha de coqueiro, folha de eucalipto, folha de café, folha de uva, pimenta calabresa, azeite de Dendê e chifre. Às vezes, pode haver variação de algum ingrediente.

A defumação de domingo, em que trabalham com a linha de Cosme e Damião, usa-se açúcar cristal, coco ralado, cravo, canela em pau, erva-doce, flor de laranjeira, noz moscada e rosa branca.

Nesses rituais de obrigações pode-se ver também a vivência da própria casa, onde nessa "conversa" entre vivos e "mortos", os filhos umbandistas são chamados à ação.

Ao contrário do que o leitor possa pensar, o trabalho para as entidades parece ser prazeroso para quem o pratica. A preparação dos banhos e as oferendas carregam consigo um repertório de aromas e cores que agradam os sentidos.

Com efeito, as ervas não servem apenas para "limpeza" ou perfumar o terreiro. Joana ostenta, com orgulho o fato de nunca precisar ir ao médico e ter sempre tratado seus filhos em casa por meio do conhecimento de usos de raízes e ervas, com receitas que foram passadas por sua mãe.

Essa prática também é bastante difundida pelas entidades durante os atendimentos realizados. Pai José, preto-velho recebido por um dos médios da casa, oferece suas garrafadas, as quais são preparadas pelo próprio médio e ofertadas aos seus consulentes, quando necessário. Não apenas os pretos-velhos, mas outras entidades como Cosme e Damião, caboclos, ciganos e pombas-gira também ensinam seus consulentes a fazerem banhos, chás ou simpatias. 
Nessa prática é possível observar que corpo e alma são cuidados pelas entidades. Pois, antes de oferecer a garrafada ou ensinar a receita para que o próprio consulente a faça, a pessoa é ouvida em suas queixas e suas mãos estão sempre em contato com as mãos do próprio médio/entidade. Quando não, o médio/ entidade está com suas mãos sobre os ombros do consulente. Esse ato é muitas vezes sentido pelo consulente como "estar junto", nesse momento de "precisão". Na maioria das vezes, as entidades também pedem para que o consulente retorne e o procure nos dias ou semanas seguintes, de forma a dar continuidade ao atendimento e assim, juntos, eles poderem sanar o problema.

Conforme o combinado, nos dias seguintes lá estão os consulentes retornando ao "tratamento", geralmente satisfeitos com os resultados. É importante dizer que as enfermidades tratadas são torções, indisposições, gripes e angústias. Quando necessário, as entidades recomendam que o consulente vá ao médico também. Em geral, as pessoas que mais seguem as orientações das entidades são aquelas que estão excluídas de um sistema de saúde decente.

De acordo com Montero (1985), a maioria dos participantes de um terreiro de umbanda usam o sistema público de saúde e descontentes com sua precariedade e as enormes filas, estes optam pelo tratamento religioso. Luc Boltanski (1959 apud Montero, 1985, p. 80) comenta que no sistema médico há o "fenômeno de desapropriação das sensações pela privação da linguagem institucional", no qual o doente não pode relatar suas sensações sobre a doença e, quando o faz, os médicos não o levam em consideração. Os doentes deveriam relatar numa ordem cronológica a aparição dos sintomas.

No entanto, a procura não é feita apenas pela falta de oportunidade de atendimento médico adequado. Há na atualidade, em muitos meios, uma revalorização dos chamados "tratamentos naturais". Além disso, terapêuticas com ervas remontam as nossas próprias origens indígenas, portuguesas e africanas que, somadas, nos oferecem uma extensa farmácia de medicamentos naturais, que tendem a ser bastante valorizados em diversos segmentos sociais. 
Com efeito, Joana ensinou algumas receitas aprendidas com sua mãe. Disse que guardou apenas algumas na memória, mas muitas plantas também não se encontram mais.

"Se vê, pra onde que a gente olha só tem cana!"

(Depoimento Joana - 14/07/2008)

Uma das plantas citadas foi a Calunga, segundo Joana

“... é uma raiz do norte, você faz um chá com a raiz. Os povo antigo usava pra baixar febre, dor no estômago, [fica pensativa], é margoso, mas funciona."

(Depoimento Joana - 14/07/2008)

Ao procurar sobre essa planta de nome desconhecido em nossa região, encontro que

“É uma arvoreta perenifóla, de 3-5 m de altura, pouco ramificada, nativa do cerrado seco do Brasil Central, desde Pernambuco até Bahia, Minas Gerais, Goiás e Mato Grosso. [...] Em Mato Grosso sua casca tanto do tronco quanto do rizoma, é empregada pelos índios e não índios para o tratamento de dispepsia, febre, edema, cicatrização de feridas, úlceras gastro-duodenais, antidisentérica, dores reumáticas, machucaduras, e obesidade, principalmente na forma de decocto e chás (BARROS, 2007, p.14)."

Barros (id.) também aponta dois estudiosos, Peckolt e Moretti, que relatam a indicação do caule e das raízes da calunga para o combate da malária, febres, diurética, e digestiva. 


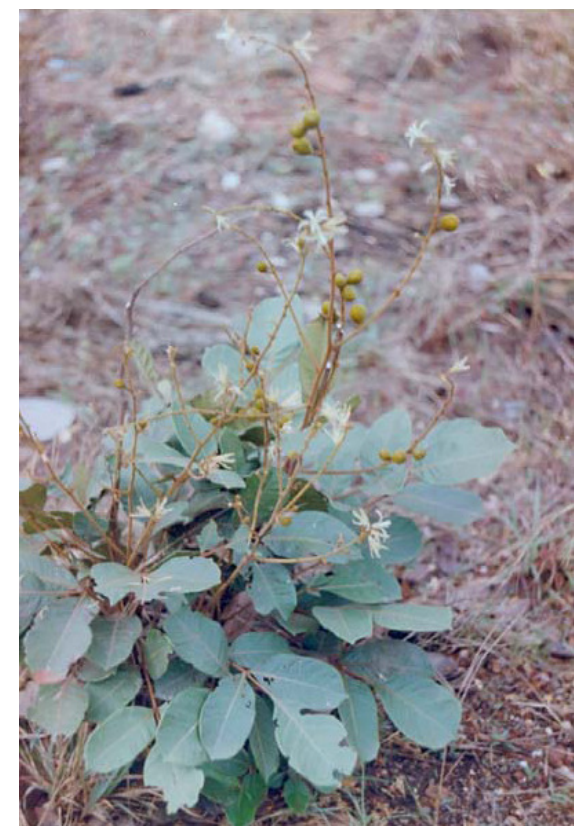

Figura 28: Calunga (Simaba ferruginea St. Hil ) - arvoreta florida e com fruto. foto: Wander Miguel de Barros, fevereiro de 2004.

Assim como Joana havia instruído sobre o uso desta planta, encontro em uma tese de doutorado quase as mesmas orientações e indicações, como também a sua proveniência.

O algodão, segundo Joana, também pode ser usado quando ainda estiver como uma bolinha verde no galho. Retira-se e espreme para que saia um óleo, o qual deverá ser esquentado para se pingar no ouvido. Com o algodão pode ser feito banho. Fervendo-o em água e jogando da cintura para baixo, em mulheres que tiveram filho através de cesárea ou parto normal, serve para tirar infecção.

Sobre a Aroeira, com as folhas se varre o terreiro para tirar a carga negativa, com a casca se faz o chá para curar feridas.

As folhas da pitangueira servem para fazer banho de descarrego, utilizado na linha dos caboclos.

Com a casca do Ipê Roxo pode ser feito chá para curar feridas.

Com a raiz da salsa, bem amassada, faz-se o chá para curar gripe. Cambará e Guaco servem para fazer xarope e, com eles, também se cura gripe. 
Espada de São Jorge, Comigo Ninguém Pode, Guiné, Arruda, Alecrim e alho servem para fazer banho de descarrego, sempre utilizando-os cortados em 7 pedaços ou 7 porções, no caso do alho, do Alecrim e da Arruda.

O Alecrim, utilizado sozinho, pode ser usado para fazer chá e ajudar na cura de dor no peito/angústia. Para isso, basta colocar três pontinhas da planta numa xícara de água quente.

Com o hortelã se faz chá e é bom para curar gripe, pois "limpa tudo por dentro." Também é bom para descarrego porque hortelã é de Cosme, segundo Joana. Para abrir caminhos é bom fazer banho com hortelã, manjericão, cravo, canela e erva-doce. Diz ela: "É banho de Cosme com cigano porque cigano gosta de Cosme. Você sabia que cigano gosta de criança?"

\section{6 - D. CHIQUINHA, JOANA E A FORMAÇÃO DO TERREIRO}

A história do terreiro começa muito antes da data inserida na placa de entrada.

A história começa quando D. Chiquinha, mãe de Joana e afamada vidente, apresenta algumas "visões" na infância. Joana conta que D. Chiquinha via espíritos e isso causava um grande mal-estar nos familiares, pois por volta do anos 20 , do século passado, tal comportamento era tido como desordem mental. Aos 7 anos, quando as manifestações se apresentaram, ela também começou a realizar curas através de simples orações que fazia as pessoas doentes, geralmente, dispondo suas mãos sobre o local enfermo e rezando. Já casada, D. Chiquinha foi levada, por seu marido, a um psiquiatra de Ribeirão Preto, D. Virgílio, espírita kardecista, que sugeriu que ela procurasse por um centro espírita ${ }^{3}$.

\footnotetext{
${ }^{3}$ A história sobre o desenvolvimento mediúnico de D. Chiquinha encontra-se, com maior riqueza de detalhes, em LEME, F. (2006) Usos do imaginário nos estudos afro-brasileiros e no culto umbandista.
} 
D. Chiquinha inicia seus trabalhos no centro espírita por volta dos seus 19 anos de idade, e lá permanece por 15 anos.

Nos últimos tempos de seu trabalho na "mesa branca", diz Joana referindo-se ao espiritismo kardecista, D. Chiquinha começa receber espíritos de pretos-velhos, caboclos e outros. No entanto, pela própria dinâmica da sessão mediúnica kardecista, que não permite que seus médios demonstrem alterações em seus movimentos durante a "comunicação" e também por não trabalharem com esse tipo de espírito denominado inferior, D. Chiquinha passou a ter certas dificuldades e a não compreender o que acontecia com ela.

Como diz Joana:

\footnotetext{
“...na mesa branca não balança (referindo-se à incorporação), o povo ficava tudo com medo."
}

“[...] a mesa branca já é mais gelada, te sobe aquele gelo, [...] a umbanda é mais quente, os guia é mais quente, mexem com teu corpo, com o organismo tudo por dentro."

(Depoimentos Joana - 20/06/2008)

Até que certo dia, uma média enferma que vinha de Ribeirão Preto para ser benzida por D. Chiquinha, em Jardinópolis, viu a mesma receber uma entidade e disse que, o que ela estava incorporando era preto-velho e sugeriu, então, que procurasse por D. Ludovina, mãe-de-santo de um centro de umbanda.

Joana conta que, quando sua mãe chegou ao terreiro de D. Ludovina, no momento da gira, ela logo incorporou seus guias. Primeiro, veio o Pai Benedito e depois todos os outros guias, tais como caboclo, baiano e exu, tendo como guia de cabeça Oxossi e Omulu. 
Com o tempo, um jovem médio do terreiro de D. Ludovina passou a acompanhar D. Chiquinha em sua casa, quando essa recebia seus guias, para benzer as pessoas que a procuravam. Segundo Joana, esse jovem era quem camboneava sua mãe e também dava orientações a ela sobre como abrir uma gira, como receber os guias que ali chegavam. Os trabalhos eram tantos que o tal jovem passou a morar na casa de D. Chiquinha e foi criado como mais um filho dos tantos que ela já criava.

Dessa forma, D. Chiquinha, atendendo em sua residência, aos que a procuravam para benzer, logo passou a não utilizar mais o espaço interno da casa. Deslocou-se para o espaço de terra que havia nos fundos da mesma. A essa altura, sua fama já crescia como boa curandeira, e o local foi tornando-se um terreiro de umbanda.

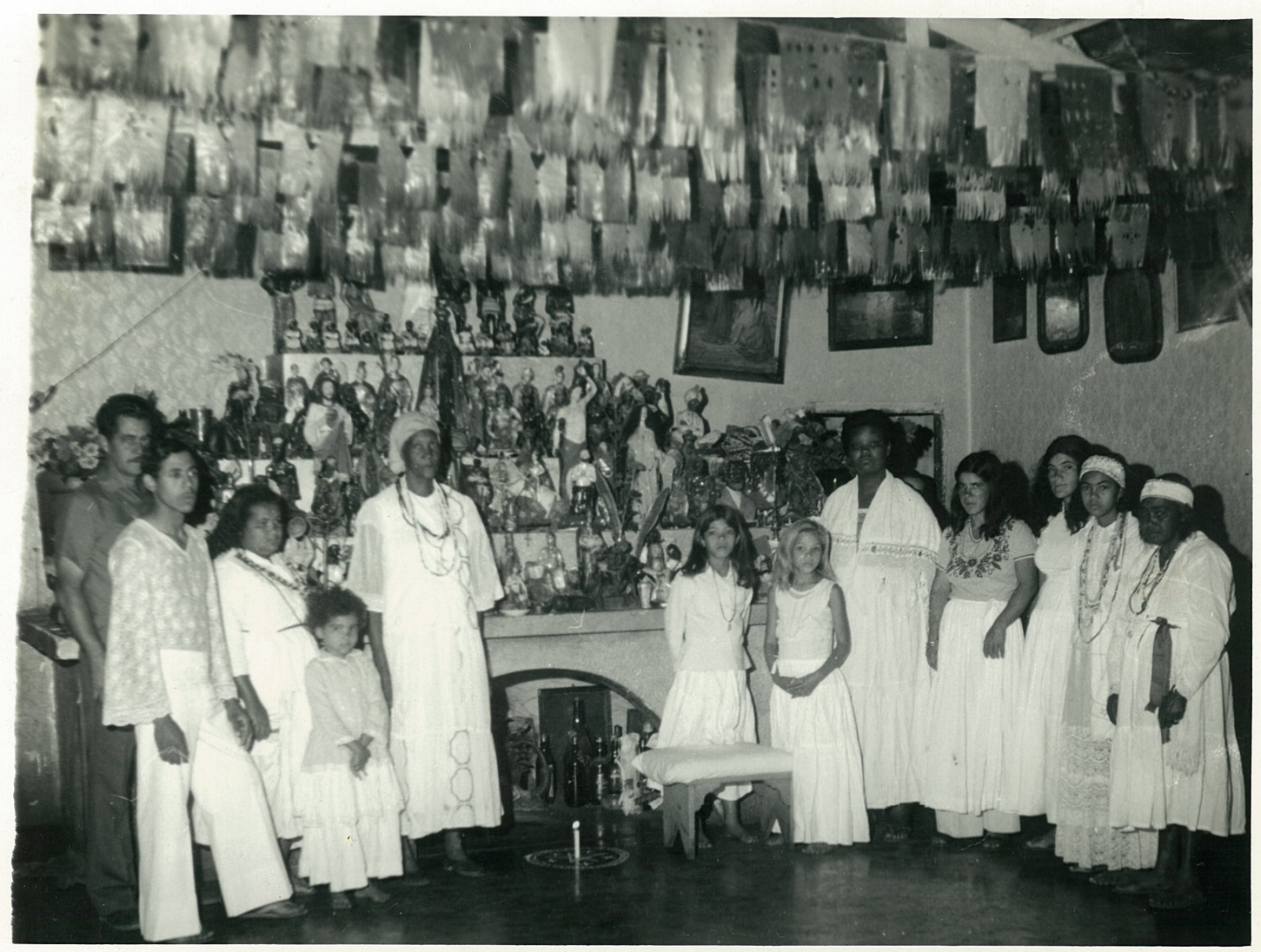

Figura 29: Foto sem data. Início do terreiro no local onde é hoje, segundo Joana. 
Na época, conta Joana, que sua mãe atendia vários fazendeiros da região para benzer plantações de café contra as pragas na lavoura.

O terreno em que o centro está instalado hoje, foi presente de um dos fazendeiros, em agradecimento aos serviços de D. Chiquinha. O local chegou a funcionar com cerca de cem médios e a assistência fazia fila para entrar no centro.

Segundo Joana, durante toda a trajetória da mãe, ela foi a filha que sempre esteve mais próxima e, como a mãe, também desenvolveu sua mediunidade com aproximadamente 7 anos.

Contudo, quando a mãe foi preparada por seus guias para desencarnar, com exatamente 79 anos, Joana conta que D. Chiquinha passou a orientar a filha para "receber o bastão*" sem que ninguém soubesse, nem mesmo Joana. Assim, quando D. Chiquinha já estava muito enferma, acometida por diabetes, ela chamou a filha para benzer uma pessoa que havia chegado no centro. Disse a ela, naquele momento, ela passava-Ihe o bastão, uma vez que, Joana era uma pessoa muito boa e saberia continuar o seu trabalho. Joana disse não ter entendido muito bem, mas foi assim mesmo.

Dias depois, no velório da mãe realizado no próprio terreiro, conta Joana que havia sido pedido para que ela cantasse um ponto de despedida para sua mãe. No entanto, ela não sabia que ponto era esse, mas orientada por um irmão de criação e também médio, ela segura a mão de sua mãe morta e apóia a sua cabeça na cabeça de sua mãe. Começa, então, a entoar o ponto.

Dessa forma, Joana assume como mãe-de-santo. Mas, foi preciso esperar sete dias para que ela pudesse entrar no terreiro novamente e só então assumir o que ela temia: ser mãe-de-santo. Durante esses 7 dias, Joana foi orientada pela mãe, que a instruiu dizendo que não precisaria preocupar-se com absolutamente nada porque tudo Ihe seria revelado através dos guias, em sonhos (conta ela, com os olhos marejados). Razão pela qual Joana sempre repete: 
“... essas coisa a gente já nasce com isso, a gente não escolhe ser mãe de santo, isso é um dom que Deus deu. Não existe essas coisas de estudá pra ser média, ou é ou não é ..."

(Depoimento Joana - 12/02/06)

Num sonho revelado por Joana, ela diz que estavam todos os médios no terreiro vestindo camisetas verdes, saias e calças brancas quando sua mãe chega, com as mesmas cores e cruza uma espada sobre o corpo dela, preparando-a para a nova missão.

Segundo Joana, seu relacionamento com a mãe era muito forte e diz que ambas já viveram juntas numa encarnação passada, não como mães e filhas, mas como duas madres que faziam caridade.

Com efeito, sempre que Joana nos conta essa história ou outras histórias sobre sua mãe é notório o tom de admiração pela mesma. A mãe aparece como um eu ideal. E, dessa forma, Joana procura seguir, em tudo o que for possível, os feitos da mãe, perpetuando a história de caridade de D. Chiquinha.

Ainda hoje é possível encontrar o Sr. Narciso, médio de 80 anos que trabalhava com D. Chiquinha, freqüentando as giras comandadas por Joana. Ele faz muitos elogios a Joana por seguir os costumes da mãe, mas diz que D. Chiquinha era mais exigente com os médios quanto à questão de horários e obrigações a serem cumpridas pelos médios. 


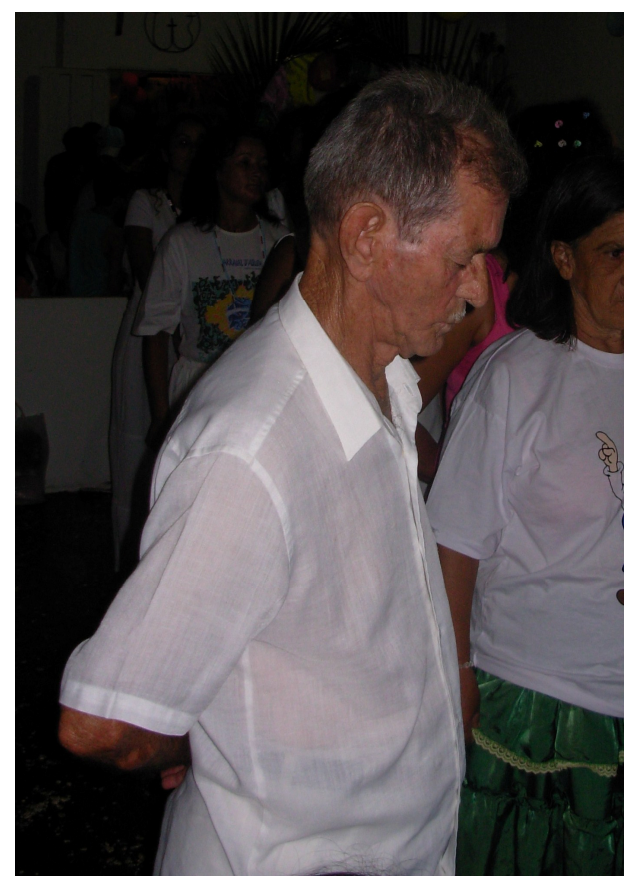

Figura 30: Sr. Narciso, médio mais antigo do terreiro. Trabalhou com D. Chiquinha.

Mesmo Joana tendo herdado todos os guias de sua mãe, os quais ainda hoje regem o centro, ela também trabalha com os seus guias e diz que possui duas "coroas", a sua e a de sua mãe, o que a torna muito protegida contra as demandas recebidas pelo centro.

Por ter uma linha de baianos muito forte, diz ela que eles ajudam a comandar o centro juntamente com Pai Benedito.

Abaixo, apresento um recorte onde Joana fala um pouco mais sobre as entidades.

Joana - Pai Benedito é um preto-velho, ele não é assim pretinho, pretinho, ele é meio mulato. Ele é pretinho assim por causa da vela. Ele, então, é um preto-velho que sempre fez muita cura, muita caridade, morreu com 120 anos, acho que foi. Ele foi escravo, depois ele teve a libertação dele, foi trabalhar na casa grande. Ele era preto-velho da minha mãe. Mas a minha entidade mesmo é baiano. Baiano forte é baiano que não brinca, se ele fala eu vou te ajudá, ele ajuda, se ele te falá eu vou dá um coro nele, vixi! Com ele é assim, não tem brinquedo. Preto-velho passa a mão na cabeça, com outra entidade não é assim. Preto-velho é 
forte mas na hora, do lado, baiano é mais forte. Se sabe, baiano tem o coração no pé!

Pesquisadora - Como assim?

Joana - Minha mãe que falava (risos). Não sei se tinha mesmo.

Pesquisadora - Como assim?

Joana - Ele não tem dó. Não tem dó, ele ajuda mas se for pra dá o porrete ele dá. Agora o preto-velho tem mais dó. $O$ Pai Benedito é assim, é mais pra cura, pra arrumá serviço, se a pessoa ta doente, tem dor. Preto velho não gosta de puxa homem com mulher, preto-velho não faz isso. Baiano faz, pomba-gira faz, exu também não gosta. Baiano tem dó, ele toma sua dor e vai em cima de quem ta te fazendo sofrer. Pai Benedito tem muita luz, luz memo, desde a época da minha mãe e na minha ele faz muita cura, ta vindo muita gente aqui com pobrema memo, e a pessoa ta ficando boa. [...] As entidades era gente igual nós, os preto-velho sofreram tanto que eles não faz mal pros otros, eles tem dó.

Pesquisadora - Exu foi o que?

Joana - Exu era redemum, redemum que eu falo é ruim. Ele só é ruim se cai na mão de gente ruim, mas se cai numa mão boa ele fica bom, fica doutrinado exu ganha luz também, o Sete tá quase pra ganha luz, aí pode virar caboclo, baiano e até preto-velho, porque ele já faz caridade, ele não é assim igual os outro. Só que ele é assim, se ele vai te ajuda ele te ajuda, se ele vai te dá o coro ele dá, ele não brinca. Se tive pomba-gira no terreiro ele não arreia porque ele fala que mulher só serve pra fazê arruaça. Chego no meio de mulher e ele desincorpora mesmo. Caboclo também é bom, mas eu trabalho poco, não que farta aqui, é que precisa de gente pra ficar cantando porque ele precisa ficar rodando. É uma entidade mais difícil pra lidar, Ogun não conversa nada mesmo. Oxossi traz saúde, paz, prosperidade e marra caboclo, caboclo não, marra exu. Se vier uma demanda no terreiro e ocê soltou Oxossi e soltou Cosme, hum! Não fica nada. A linha de criança levanta terreiro, ela quebra a demanda do terreiro. É forte.

Pesquisadora - Com criança ninguém pode!

Joana - (Joana sorri)

(Depoimento Joana - 11/09/2008)

Quando perguntada sobre quem herdará o bastão agora, Joana diz não saber.

No entanto, em algumas conversas, Joana acredita que pela tradição seria sua irmã Meire ou sua filha Gisele que também trabalha como médio no centro, mas diz não saber porque a vida de mãe-de-santo é muito difícil, pois é um trabalho de dedicação intensa, doando a própria vida para a caridade, como costuma dizer. 
Segundo Joana, quando o médio faz um descarrego numa pessoa, ele pega tudo o que a pessoa tinha de ruim. Também se ele vai em algum ambiente que está "carregado" (refere-se à energia ruim) acaba passando mal, e fica com dor de cabeça, náuseas e dores pelo corpo.

Joana explica que os médios possuem seus guias, que os ajudam a se livrarem desses mal-estares, mas até que isso ocorra leva-se um tempo.

"... a gente faz o bem pros otro e pega o mal pra nós..."

(Depoimento Joana - 11/09/2008)

“... por isso que eu falo, que se eu for não vai ter ninguém pra ficar aqui. Se vê a Meire é toda nos trinques, por isso que eu fico com o pé atrás, mas se não tiver ninguém eu levo a missão. Quando minha mãe tava me preparando era minha menina que tava sempre comigo nos sonhos."

(Depoimento Joana - 13/10/2008)

\section{7 - USOS E COSTUMES}

Até o momento descrevi algumas características e estruturas da casa, mas agora contarei como é que se vive tudo isso, ou como é que vivem vivos e mortos dentro do terreiro de Pai Benedito.

Tudo o que foi contado, até então, nos dá indícios do que nos espera nessa casa... 
O portão sempre aberto é a mensagem de que todos podem entrar. Basta chamar pelo nome de Joana, na sua casa, que ela prontamente virá com as chaves para abrir o terreiro e atendê-lo.

Durante todo o dia há homens, mulheres e crianças a procura de um atendimento com Pai Benedito. Joana incorpora sempre que há um cambone para atender a entidade - Pai Benedito -, caso contrário, ela apenas benze a pessoa que a procurou. Algumas vezes, cansada com as tarefas da casa e também da mediunidade, Joana desabafa:

“o poblema não é só benzê, incorporá e disincorporá, o duro é a carga negativa que a gente pega de quem vem benzê e aí a gente passa mal. Tem vezes que inhantes da pessoa chegá eu já começo a senti dor de cabeça e aí, depois vem a pessoa pra benzê com dor de cabeça".

(Depoimento Joana - 11/09/2008)

Joana é mãe de quatro filhos e tem três netos, até o momento. A casa, extensão do terreiro ou terreiro extensão da casa, vive cheia de parentes porque Joana tem muitos irmãos e estes vivem em casas próximas. Há sempre algumas primas de sua mãe que são médias e, geralmente, freqüentam as giras para serem benzidas.

No quintal, que liga terreiro e casa, vivem gatos que dão cria e ficam com seus filhotes por ali até tomarem novos rumos, há galinhas e cachorros convivendo em harmonia. Pelos cantos, vemos sempre montinhos de comida ora dados por um, ora dados por outro. $\mathrm{O}$ cachorro, um vira lata preto, geralmente entra no terreiro durante as giras, passeia pelos médios e se acomoda em frente à tronqueira, coincidência ou não.

Durante as giras é presença notável a quantidade de crianças que perambulam por ali, ora seus netos, ora filhos de consulentes ou crianças da vizinhança que vão por conta própria. 
Cerca de quatro anos atrás, no início de minhas pesquisas no terreiro, foi imagem inesquecível, ver Guilherme - neto de Joana - com dois anos de idade, acender e transportar velas pelo congá durante as giras, como também agir como os médios durante a atividade mediúnica. A mãe da criança, sempre sentada dentro do congá e de olhos atentos ao filho, o ajudava quando ele dizia ter recebido seu pretovelho. Logo, para ele era colocado um banquinho como para os demais médios e dado um pequeno cachimbo, apagado! A criança, com sua guia cheia de contas coloridas no pescoço (cores de Cosme e Damião) sentava-se como um preto-velho e benzia as demais crianças. O menino dizia receber Pai João.

Durante algum tempo, seu neto mudou-se para Ribeirão Preto e começou a espaçar suas idas ao terreiro da avó, mas sua presença sempre foi certeira nas festas de Cosme e Damião, não mais como "médio", mas como ávido participante. Agora, Guilherme voltou a morar em Jardinópolis e o terreiro da avó continua como um de seus locais preferidos.

Sempre encontramos a presença de crianças participando das giras, como já descrito sobre a pequena médio que entoa os pontos durante as giras.

Seus netos e sobrinho estão sempre brincando no quintal ou no próprio terreiro. Quando o barulho e a bagunça excedem o permitido, levam alguma bronca. As traquinagens são vistas como sinônimos de criança saudável.

Certa vez, uma mãe levou o filho para ser benzido por Pai Benedito porque a escola estava se queixando muito do comportamento do garoto e o médico havia indicado Ritalina, um remédio em moda, usado para sossegar crianças com o famoso TDH - Transtorno de Hiperatividade, mas a mãe apreensiva com os efeitos colaterais do remédio resolveu antes benzer. Ao que Pai Benedito respondeu:

“...exi menino num tem nada. Como fala exas criança que sobe em árvore? Traquina? Ele é traquina, fia. É que agora eles num tem mais árvore pra subi e fica tudo trancado". 
A mãe continua a freqüentar o terreiro sempre que precisa, a criança nunca tomou o remédio e segundo ela, dois anos depois desse episódio, a criança, hoje, está bem mais tranqüila e ela certa de que era a própria idade da criança e a falta de tempo/paciência em que os pais vivem ultimamente. Diz que agradece a Pai Benedito por ter olhado aquela situação de uma outra maneira e não ter "dopado" o filho.

Vale dizer que, em suas práticas, Pai Benedito nunca contradiz um receituário médico e, muitas vezes, ele mesmo é quem orienta a pessoa a procurar o médico.

Contudo, Joana diz que a presença de criança no terreiro ocorre desde a época de sua mãe, que gostava muito delas e diz também gostar muito de criança. Ela procura reproduzir quase tudo o que a mãe fazia quando era mãe-de-santo. A presença de D. Chiquinha se dá não apenas pela continuidade dos usos e costumes da época em que comandava o terreiro, mas também com sua presença espiritual.

D. Chiquinha sempre aparece em sonhos para Joana, quando não, a filha a vê no terreiro. Abaixo do quadro de D. Chiquinha pendurado na parede, há uma pequena mesa com uma toalha branca, onde sempre tem uma vela branca acesa. Depois de um sonho com a mãe, ao lado dessa mesa está uma cadeira que não se pode ocupar, diz Joana ter visto a mãe sentada naquele lugar.

O pai de Joana veio a aparecer na pesquisa quase no seu final, quando Joana me contou sobre a visita de uma moça vidente que havia ido ao centro para benzerse e, sem saber de quem se tratava, descreveu à Joana a pessoa que estava vendo perto do quadro de D. Chiquinha. Segundo Joana era seu pai e, desde então, ela busca uma foto do pai para ampliá-la e colocá-la ao lado da foto da mãe. Nesse dia, Joana me contou um sonho que havia tido com o pai há poucos dias:

Joana:Semana passada sonhei com ele, ele me deu uma bacia de milho, não cascado, milho com a casca verde. Eu cheguei numa casa e aí ele chegou de carrinho, carrinho mesmo de animal. Um cavalo assim branquiiiiiinho, com as crina assim caído, sabe? Ai ele falou assim: 
Joana, pega um pouco de milho ai procê e eu falei: Vô levá aonde? Ai ele pegou assim a bacia, e até a bacia era verde, ele me deu. Parecia que era de barro. Modo de que eu vô leva a bacia e como é que eu vô trazê de volta? Ele falô assim: vô te dá uma sacola e pegou uma sacola verde, aquelas assim um bornal, aqueles de antigamente, ai eu vim naquela reta cumpriiida, era verde cheia de flor. Ele tá quase pra ganha a luz, ele já tem muita luz, ele entende que já morreu, se tem argum neto com perigo ele ajuda também, mas ele vai ganhá mais luz.

Pesquisadora: $O$ que será que ele quis dizer?

Joana: Não sei, pode sê que minha vida vai caminhá porque é reta comprida.

Pesquisadora: E o milho, tem algum significado?

Joana: 0 milho quer dizer fartura, sê pode ver, pra abrir os caminho se pega a espiga do milho, da uma fervidinha nele, põe numa bacia de barro e põe na mata, isso ai é abertura. Então é isso! Talvez é isso que ele qué que eu faço. Eu tô aqui conversando com você e daí a gente vai indo né, se vê? Tem guia que gosta, se vê o Tupinambá, se faiz um mingalzinho de milho sem doce, sem nada, põe pra ele e ele ajuda (pausa, risos) é conversando que a gente se entende e vai pondo as coisas no lugá.

(Depoimento Joana - 17/04/2009)

Sobre o pai, também aparece a lembrança das danças de roda das quais via a família paterna participar, tanto quando ainda moravam em fazendas, como posteriormente, no terreno de Jardinópolis em que até hoje se ergue o terreiro e se foram construindo varias moradias da família. Joana conta que só participavam os homens e as mulheres, as crianças, apesar de quererem muito entrar na roda, apenas assistiam e acompanhavam com palmas. Lembra que os primeiros, descalços e com as mãos para trás, inclinados para frente, dançavam em roda, movimentando-se em sentido horário e cantando numa língua para ela incompreensível. Essa dança chamavam-na "moçambique". Só era realizada quando preciso, mas não se recorda da razão porque acontecia. 
Passado alguns dias, Joana encontra uma foto do pai.

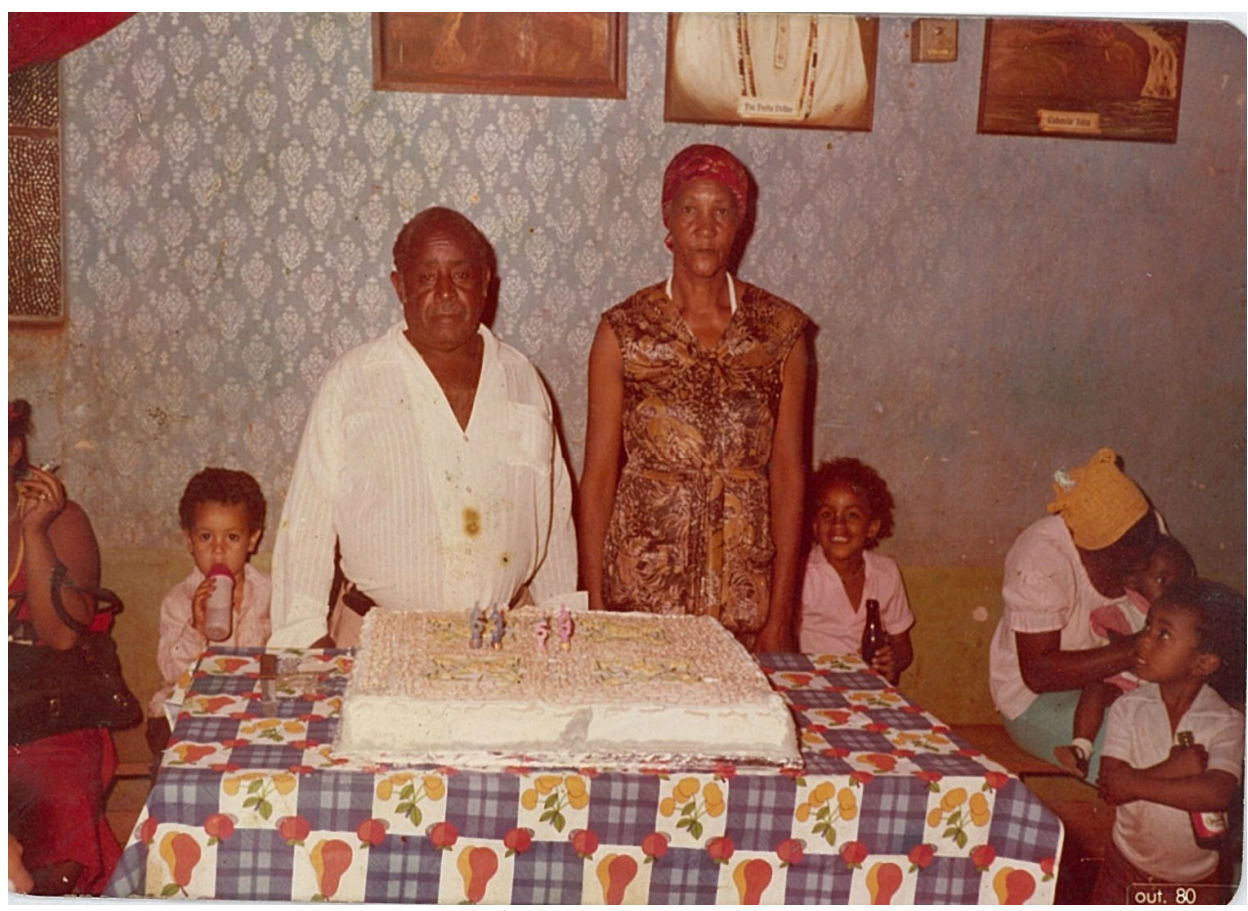

Figura 31: Pais de Joana, outubro de 1980.

Assim como a cadeira reservada para a mãe de Joana, há também alguns banquinhos de madeira em que ninguém pode se sentar, pois são reservados ao Pai Benedito. Por falar em sentar-se, nunca podemos fazê-lo de costas para o pejí quando estamos dentro do congá, apenas nas giras de esquerda. Ficar parado perto das portas do terreiro também é outra coisa que não podemos fazer, segundo Joana e também Orestes, esses lugares possuem sempre entidades que são deixadas ali pelo descarrego e elas podem acabar "montando" em você para não irem embora.

As crenças e os rituais estão presentes a todo o momento. Bolsas nunca podem estar no chão. Ao se acender uma vela para as entidades de direita é preciso, antes, tocar o chão com as pontas dos dedos da mão direita (como uma saudação e um pedido de licença) por três vezes no local onde se acenderá a vela. Se for para entidade de esquerda deverá repetir o processo com a mão esquerda. 
Antes do médio iniciar o trabalho no centro, ele deverá bater 3 vezes a cabeça no altar, bater a cabeça no chão em frente ao altar, bater a cabeça no pé da mãe de santo, acender uma vela para o Anjo de Guarda e fazer uma prece, pedir benção para mãe de santo e para a mãe pequena. Quando o trabalho terminar, o médio deverá bater a cabeça no altar 3 vezes, bater a cabeça no chão em frente o altar, pedir benção para a mãe de santo, salvar os outros médios e salvar a tabaca (essas normas encontram-se descritas por Orestes no anexo 2).

Pingar vela derretida no chão para fixarmos a própria vela é algo que não se pode fazer. Devemos equilibrar a vela sem nenhum subterfúgio e, se a vela não parar, é porque algo há de errado como, por exemplo, a entidade não aceitar seu pedido ou ele estar sendo feito para a entidade errada.

Histórias com velas encontramos aos montes. Uma delas é quando Joana conta que sua mãe estava no hospital e ela havia ido até o terreiro para acender uma vela e rezar pela saúde de D. Chiquinha. No entanto, essa vela não queria acender de forma alguma. Então, Joana voltou para casa e disse ao marido que sua mãe tinha morrido. Realmente, minutos depois chega a notícia de que a mãe havia falecido.

Sendo os primórdios da umbanda uma religião de poucas escrituras, logo poucas leituras, o filho de santo é chamado a retribuir e a demonstrar seu respeito para as entidades através do trabalho com o próprio corpo. O mentalismo ou racionalismo encontrados em outras religiões, como o espiritismo kardecista ou o catolicismo - praticados por uma população com maior nível de letramento e nível social, na umbanda tradicional não encontrará espaço. Tanto os agradecimentos quanto os pedidos feitos para as entidades não são feitos através de incansáveis preces, orações, novenas ou coisas do tipo. Pode-se rezar e é bom que o faça, mas aqui o que se pede é o trabalho, a ação.

E assim, os eventos que exigem uma maior rigidez de atitudes são sabiamente delegados. $\mathrm{O}$ aniversário de morte de D. Chiquinha (falecida em 30 de agosto de 1991), que é sempre lembrado, celebra-se com missa. Missa? Pergunta-se o leitor. 
Isso! Joana é casada na igreja católica e seus filhos e netos são todos batizados no catolicismo para depois receberem o batismo dos guias.

Joana diz que uma criança não pode ser benzida por uma entidade sem ter sido antes batizada, ter recebido as bênçãos do padre. Por que isso? Talvez a explicação esteja no sincretismo ou além dele.

Assim como Joana vai à missa, também recebe visitas de pais-de-santo do candomblé e também os visita. No entanto, Joana diz não gostar muito do candomblé porque é uma religião onde há matança de animais e ela não gosta, como também diz que a religião é muito "luxenta", pois suas vestes e suas oferendas são muito caras, só podendo participar pessoas que têm dinheiro.

Nessa mistura de catolicismo, espiritismo e candomblé surge a umbanda do Terreiro de Pai Benedito, magistralmente dirigido por Joana, a qual agrega a todos sem distinção, trazendo a preocupação com a caridade e o compromisso com a tradição, onde o valor não está nas escrituras ou leituras, mas na prática do bem. 


\section{CONSIDERAÇÕES FINAIS}

"Incorporando" aquele que me trouxe até aqui, exponho, agora, as possibilidades de significados que se revelam pela própria vivência, pelo próprio caminhar do trabalho.

Durante esse percurso acabei entendendo, realmente, o que é exu. Exu representa as incertezas da explicação, a abertura e a multiplicidade de significados de cada texto, tornando-se, portanto, o próprio processo de interpretação (GATES,1988, p.21 apud FONSECA, 2000). Assim como ele, que permeou todo esse trabalho, apresentei minhas andanças pelo Terreiro de Pai Benedito evitando cair nos engodos da interpretação.

Exu não é teoria. Não é mal. É mensageiro. Exu é ação!

É preciso estar em movimento para conhecê-lo.

Através dele, cheguei a essa pesquisa e em alguns outros lugares...

Crapanzano (1986) que tão bem equiparou o etnógrafo a Hermes, deus da mitologia grega muitas vezes associado a Exu, possibilitou que o próprio estivesse presente em todos os movimentos desse trabalho através das minhas ações.

Como sendo o princípio de todas as coisas, exu me trouxe até à pesquisa, mas como gosta de introduzir o acaso na vida das pessoas, me levou para um terreiro em que eu havia ido quando criança e "não" me lembrava mais do fato. Não o bastante, assim como fez com Ifá*, decidiu compartilhar um pouco do seu poder com a cigana e a trouxe para essa história, mudando a ordem que havia sido estabelecida.

Como cabe a ele também recuperar o marginal e cutucar o recalcado no ser humano, no que está inconsciente, despertou histórias que estavam adormecidas não apenas em mim, mas na própria comunidade umbandista, pois "toda lembrança vive em estado latente, potencial" (BOSI, 1994, p. 51). E assim, figuras que estavam esquecidas ganharam forma, cheiro e voz. 
O trabalho verdadeiramente começou quando não mais resisti à separação entre pesquisador e comunidade pesquisada, e mergulhei no universo da umbanda. Jamais conheceria suas sutilezas se não tivesse acendido velas para "minha cigana", se não tivesse feito muita canjica para os pretos-velhos ou se não tivesse tomado os banhos perfumados que, várias vezes, foram receitados.

Silva (2006) coloca que participar da religião ajuda a entender melhor o agir da comunidade e ganhar o respeito da mesma, pois ao pesquisador é atribuída uma identidade religiosa que o torna uma pessoa "reconhecível" no grupo. Segundo esse mesmo autor, "quem experimentar não precisa perguntar" (p.90).

De acordo com Bairrão (2001), Corbin sustenta que, para poder conhecer, o estudioso tem de se colocar numa posição compatível com o horizonte de ser que será estudado, sob pena de se mostrar incapaz de o descrever. E acrescenta:

“Corbin explicita-o, afirmando a importância de se colocar no interior da consciência religiosa, acessível à presença do sagrado, para poder se pôr na perspectiva correta ao seu estudo:

"Há uma polaridade entre o objeto que se mostra e aquele a quem ele se mostra. Para que o pesquisador dele possa falar por sua vez, é necessário que este objeto se mostre a ele, é necessário que uma nova polaridade se estabeleça (CORBIN, p.105 apud BAIRRÃO, 2001)".

Acredito também que, no estudo da religiosidade afro-brasileira é preciso olhar para o que se revela, mas que nem sempre se mostra.

A cigana me levou a viajar por terras desconhecidas, não me revelou o futuro, como é característico do povo cigano mas, talvez, por armação de exu, sob a incidência das inversões que este tanto gosta de cometer, ela me permitiu "ver" o passado. Entre as histórias sobre meus estudos, que eu trazia para a casa de meus pais, aparece outra história, a da minha própria mãe. Relembra que, quando jovem tinha os cabelos compridos e negros, usava sempre lenço na cabeça e gostava muito 
de usar jóias com formato de moedas. Era muito vaidosa, e as pessoas a chamavam de Ciganinha.

A incidência deste termo (porque não dizê-lo, deste significante?), recorda que os significantes estão presentes no contexto social, histórico, nas memórias, na fala, no não-dito. Exu, tal como Hermes, o deus da linguagem e da interpretação, traz esse significante "cigana", que volta hoje, para designar a filha da "Ciganinha".

Em uma das conversas que tive com a cigana Jacira, ela havia me pedido para que eu cuidasse mais da minha aparência porque minha cigana não gostava de me ver daquela maneira. Ela - minha cigana - queria o melhor pra mim.

"Cigana" como encruzilhada significativa também atesta o princípio dialógico postulado por Bakhtin, quando diz que cada palavra é polifônica e seu significado é determinado por incontáveis contextos em que foi previamente utilizada, carregando consigo os traços de todos os sujeitos, possíveis e reais, que já empregaram tal palavra.

Ela não aparece apenas nesse contexto subjetivo e psicológico, individualizado, me fazendo refletir a relação mãe e filha. Ela circula "misteriosamente" numa esfera interpessoal, tangível linguisticamente, pois a cigana também aparece numa rede social. Uma amiga que está morando na Escócia me ligou impressionadíssima com um sonho que havia tido com uma cigana, onde ela pedia para me contar que seu nome era Mariah (com " $\mathrm{h}$ " no final) e que eu deveria fazer um trabalho para tirar o "estigma" que os ciganos sempre carregaram, o que os fazia sofrer perseguições mesmo depois de mortos.

Intrigada com o nome Mariah, faço uma pesquisa rápida para saber se na umbanda existem ciganos com este nome. Descubro que Mariah é a cigana que roga pragas!

Como os ciganos, os significantes circulam. Trazem significados e ressignificam vivências populares, criam laços entre as pessoas e implicam situar-nos, possibilitando que um sujeito daí surja. 
O baiano, uma das entidades que Joana mais gosta de receber, também aparece nomeando o pai: “... meu pai era pequeninho, era baiano lá de Moçambique". A mãe era mineira.

Depois de ouvir muitas histórias sobre a mãe de Joana, quase no final da pesquisa, ela fala sobre seu pai, conta um sonho com ele e revela que o pai "tinha vidência", que era "médio firme" e ficava no quartinho do centro ajudando a mãe. "Ele era a escora da minha mãe". Depois disso, começou a buscar uma foto dele para colocar ao lado da foto da mãe no terreiro. Diz ela: "assim completa, né?"

E me deu uma foto de seu pai para ampliá-la.

Bosi (1994) coloca que "lembrar não é reviver, mas refazer, reconstruir, repensar com imagens e idéias de hoje, as experiências do passado."

Quando Joana coloca que "é conversando que a gente se entende e vai pondo as coisa no lugar", mostra sem saber, um dos sentidos do contar histórias, narrando se vai ordenando os acontecimentos e ressignificando as vivências. O que Joana completa ao colocar a imagem do pai ao lado da imagem da mãe?

Ao significar esses acontecimentos, Joana anuncia algumas mudanças (ainda em sigilo) que refletirão no trabalho da casa.

O modo umbandista de lidar com a significância reforça elos com a sociedade circundante. Ao abrir suas portas na festa de Cosme e Damião permitindo que toda a criançada da vizinhança venha compartilhar daquela alegria que certamente faz perpetuar uma tradição. As crianças ali presentes são vistas e tratadas como se fossem os erês*, espíritos da linha de Cosme e Damião. Recebê-las é como tratar bem assas entidades. Os médios brincam com as crianças repartem seus doces com elas, rolam no chão, sujam-se e fazem bagunça. Nessa interação, ensinam às crianças, de maneira lúdica, a religião e, aos adultos o dever de tratá-las bem. Todas e também a "sua".

Deste modo, a vivência praticamente física e sensorial da significância abre passagem para a inclusão social de permeio à readmissão de significados 
eventualmente recalcados ou depreciados e, através prática umbandista, transmitem valores éticos e morais.

Na umbanda, do terreiro de Pai Benedito, o morto aparece com reverberações metafóricas, o que estaria reprimido ganha corpo. Há uma vida social que inclui o morto e portanto, ele está vivo nos significantes que ali circulam.

A vivência psíquica desse morto passa a ter vida e influenciar a construção da história dos vivos. Não se trata aqui de discutir e, nem negar a concepção religiosa de que o morto tem vida, mas de vermos o alcance social e psicológico que acaba refletindo na vida dessa comunidade. O "morto" acaba por configurar um modo de dar sentido à vida.

Do ponto de vista psicológico, é inegável que as construções de sentidos possibilitadas pela "vida" do morto na comunidade possibilitam transformações pessoais, possibilitam a reintegração de conteúdos "psíquicos" ou pedaços da própria história "esquecidos" e o fazem ao mesmo tempo em que criam ou ressignificam laços sociais. Em suma, promove concomitantemente a inclusão social e a intrapsíquica.

Este trabalho se mostrou como uma encruzilhada de significados e me fez lembrar o conceito de significante para Lacan, que com outras palavras vai dizer que o significante é uma encruzilhada para diferentes significações.

O "morto", na qualidade de significante, promove uma riqueza e sutileza de recursos expressivos que fortalece laços interpessoais e intergeracionais.

Por meio do conceito de "espírito", a umbanda explora com habilidade a capacidade dos significantes de ao mesmo tempo serem universais e poderem ser muito específicos. Um significante muito geral pode ter uma incidência muito particular em alguém e vice versa, algo muito específico se revela (vide, por exemplo, a "descoberta" da filiação da pesquisadora à Cigana).

Deste modo, a reanimação de memórias e recordações, intrínseca aos labirintos da significância e da associação livre tal como amplamente é reconhecido em psicanálise, parece ganhar vigor persuasivo quando se supõe como subjacente as 
encruzilhadas da significância a atuação intencional de agentes espirituais capazes de se mostrarem em movimentos, aromas, sensações corporais e alegarem algum tipo de parentesco ou vínculo com os vivos (alegação que independentemente de qualquer verossimilhança por si só já estabelece um elo combinatório capaz de gerar novos sentidos).

A natureza includente desse "uso" da significância, bem como a multiplicidade e magnitude da sua incidência subjetiva, dificultam muito ou mesmo inviabilizam uma observação "externa". A pesquisadora "descobriu-se" como parte da história a ser narrada e isso mostrou-se condição relevante para a pesquisa. Além disso, alguns dos efeitos de sentido dependem do tempo da sua constituição e reconhecimento subjetivo. O ocultamento dos exus cujo estudo havia sido objetivo inicial do trabalho, por exemplo, acabou por se mostrar num modo mais radical da sua revelação.

Assim é a umbanda! Com suas entidades que representam os tipos brasileiros, trazendo significantes que despertam nossa própria história e se incumbe a dar sentido às vivências pessoais e sociais, possibilitando que cada um faça suas amarrações e teça sua própria colcha.

Essa não pára por aqui, porque terminá-la seria o fim da própria vida e, outros retalhos (significantes), ainda se juntarão, reiterando encruzilhadas de significados. 


\section{REFERÊNCIAS BIBLIOGRÁFICAS ${ }^{4}$}

AMARAL, R. (2000). Mitos dos Orixás do Candomblé Paulista. In:Textos base do curso "Mitologia e Arte Sacra Afro-Brasileiras", oferecido pelo Museu de Arqueologia da Universidade de São Paulo. ( $1^{\circ}$. Semestre)

BAIRRÃO, J.F.M.H. (2001). A Imaginação do Outro: intersecções entre psicanálise e hierologia. Paidéia - Cadernos de Psicologia e Educação. v.11, p.11-26.

(2002). Subterrâneos da Submissão: sentidos do mal no imaginário umbandista. Editorial. Memorandum. Belo Horizonte. v. 2, p. 55-67.

- (2004a). Espiritualidade Brasileira e Clínica Psicológica. In: Valdemar Augusto Angerami-Camon. (Org.). Espiritualidade e Prática Clínica. São Paulo: Thomson, p. 193-214.

(2004b) Sublimidade do Mal e Sublimação da Crueldade: criança, sagrado e rua. Editorial. Psicologia Reflexão e Crítica. Porto Alegre. v. 17, n. 1, p. 6173.

(2005) A Escuta Participante como procedimento de Pesquisa do Sagrado Enunciante. Editorial. Estudos de Psicologia. Natal. v. 10, n. 3, p. 441-446.

(2007). Linguagem e corpo na Umbanda. In: Irene Gaeta Arcuri; Marília Ancona Lopez. (Org.). Temas em Psicologia da Religião. São Paulo: Vetor Editora. p. 165-184.

BAIRRÃO, J. F. M. H.; LEME, F. R. (2003). Mestres Bantos da Alta Mogiana: tradição e memória da umbanda em Ribeirão Preto. Memorandum (Belo Horizonte), Belo Horizonte, v. 4, p. 5-32.

BARBOSA, M. V.A. (2001). A concepção da palavra em Bakhtin. Porto Velho: Primeira Versão (UFRO), v.69, p. 01-05.

\footnotetext{
${ }^{4}$ De acordo com a Associação Brasileira de Normas Técnicas. NBR 6023
} 
BARROS, W. M. (2007). Efeito do estrato hidroetanólico dos rizomas da Simaba ferruginea ST Hil. (SIMARIUBACEAE), sobre o comportamento e reprodução de ratas da Linhagem Wistar. Tese apresentada ao Curso de Pós-Graduação da Faculdade de Ciências Médicas da Santa Casa de São Paulo para obtenção de título de Doutor em Ciências da saúde.

BARTHES, R., et. al. (1971). Análise Estrutural da Narrativa. Petrópolis, RJ: Editora Vozes. p. 19-105.

BIRMAN, P. (1985). O que é umbanda. São Paulo: Abril Cultural / Brasiliense.

BOM MEIHY, J.C.S. (2001). Manual de História Oral. São Paulo: Edições Loyola, $3^{a}$ edição.

BROCKMEIER, J.; HARRÉ, R. (2003). Narrativa: problemas e promessas de um paradigma alternativo. Psicologia Reflexão e Critica. Porto Alegre, v. 16, n. 3. p. 525-535.

BRUMANA, F. G. e MARTINEZ, E. G. (1991). Marginalia Sagrada. Campinas: Editora da Unicamp.

CAIADO, M. R. M. (2006). Aluno deficiente visual na escola: lembranças e depoimentos. Campinas: Autores associados.

CARREIRA, A. F. (2002). Contando a minha história: uma técnica de trabalho de crianças em grupos para ouvir e contar histórias. São Paulo, SP: Editora Pancast.

CASAL, A. Y. (1997). Suportes teóricos e epistemológicos do método biográfico. Revista Ethmologia, Nova Série. $n^{\circ}$ 6-8. Edições Cosmos, Dep. Antropologia da Faculdade de Ciencias Sociais e Humanas, UME, Lisboa. 
CLIFFORD, J. (2002). Experiência etnográfica: antropologia e literatura no século XX. Org. José Reginaldo Santos Gonçalves. $1^{\text {a }}$ reimpressão. Rio de Janeiro: Ed. da UFRJ.

CRAPANZANO, Vincent. (1986). El dilema de Hermes: la máscara de la subversión en las descripciones etnográficas. In: CLIFFORD, James; MARCUS, George e. (Eds.). Retoricas de la antropologia. Madrid: Júcar, 1991.

FONSECA, M. N. S. (2000). (Org.). Brasil afro-brasileiro. Belo horizonte: Autêntica.

KEANE, W. (1997). Religious Language. Rewiew of Antropology. v.26. p. 47-71.

LACAN, J. (1960). Posição do Inconsciente. In: J. Lacan. Escritos. Rio de Janeiro, RJ: Jorge Zahar Editora, 1998.

LEME, R. F. (2005). Usos do imaginário nos estudos afro-brasileiros e no culto umbandista. Dissertação de mestrado apresentada como requisito parcial para a obtenção do título de mestre em Psicologia junto ao Programa de Pós-Graduação em Psicologia do Departamento de Psicologia e Educação da FFCLRP-USP. p. 01-164.

LUTZ, C. (1988). Unnatural emotions: everyday sentiments on a Micronesian atoll \& their challenge to western theory. Chicago: The University of Chicago Press.

MAGGIE, Y. (2001). Guerra de Orixá: um estudo de ritual de conflito. 3. ed. Rio de Janeiro: Jorge Zahar Editor.

MANTOVANI, A. e BAIRRÃO, J. F. M. H. (2005). Psicanálise e Religião: pensando os estudos afro-brasileiros com Ernesto La Porta. Editorial. Memorandum. Belo Horizonte, v. 9, p. 42-56.

NEGRÃO, L. N. (1996). Entre a cruz e a encruzilhada: formação do campo umbandista em São Paulo. São Paulo: EDUSP. 
ORLANDI, E. de L. P. Educação em direitos humanos: um discurso. In: Rosa Maria Godoy Silveira et alii. (Org.). Educação em direitos humanos: fundamentos teórico-metodológicos. 1 ed. João Pessoa: Editora Universitária. p. 295-311

PRANDI, R. (1996). Herdeiras do Axé. São Paulo: Hucitec.

PRANDI, R. (2006). As religiões afro-brasileiras nas ciências sociais. In: Conferência inaugural do XI Congresso Latino-Americano sobre Religião e Etnicidade. ALER Associação Latino-Amercana para o estudo das religiões. São Bernardo do Campo, 3 a 7 de julho.

QUINET, A. (2000). A descoberta do inconsciente. Rio de Janeiro: Jorge Zahar Editor.

RICOEUR, P. (1978). O Conflito das Interpretações: Ensaios de Hermenêutica. Rio de Janeiro Imago.

SALAMI, S. (1999). Poemas de Ifá e valores de conduta social entre os Yorubá da Nigéria .Tese de doutorado apresentada na Faculdade de Filosofia, Letras e Ciências Humanas da Universidade de São Paulo. Departamento de Sociologia. São Paulo.

SILVA, V. G. da. (1992). A crítica antropológica pós-moderna e a construção textual da etnografia religiosa afro-brasileira. In: Cadernos de Campo, São Paulo. Departamento de Antropologia da USP, ano 1, n.1, p.47-60.

TFOUNI, L. V. (1995). Letramento e alfabetização. São Paulo: Cortez.

THOMPSON, P. (1992). A voz do passado. Rio de Janeiro: Paz e Terra.

TRINDADE, L. (1985). Exu: símbolo e função. São Paulo: FFLCH/USP, 1985. (Coleção religião e sociedade Brasileira, v.2).

WIELEWICKI, V. H. G. (2001). A pesquisa etnográfica como construção discursiva. Editorial. Acta Scientiarum. Maringá, v. 23, n. 1, p. 27-32. 
WIKIPEDIA. (2009). Site: http://pt.wikipedia.org/wiki/S\%C3\%A3o_Benedito 


\section{GLOSSÁRIO}

Aparelho: Médio.

Cambone: Auxiliar dos médiuns quando estes estão incorporados. O cambone atende diretamente aos pedidos feitos pelas entidades, como por exemplo; buscar cigarro. O cambone também é uma espécie de tradutor e mediador entre um consulente e entidade, principalmente quando o consulente é novato e não entende o linguajar do espírito

Congá: Espaço no terreiro onde os médios incorporam e são realizados os atendimentos.

Coroa: Conjunto dos espíritos da direita que um médium recebe.

Demanda: Espécie de ataque ou conflito travado espiritualmente por meio de recursos "mágicos". Segudo Maggie é uma briga entre orixás, entre santos de um terreiro e de outro, estabelecida a partir dos homens (MAGGIE, 2001).

Desenvolvimento: Início e aprendizagem do trabalho mediúnico de um médio, quando esse começa a receber as entidades que irá trabalhar no decurso de sua vida.

Despachos: Tipo de oferenda ritual, feita geralmente com a intenção de afastar certas classes de espíritos. São oferendas aos guias. No caso dos exus, pode-se encontrar em seus despachos; pinga, charuto, panos nas cores pretas ou vermelhas (cores que identificam o orixá) e etc. 
Entrar na linha: Expressão utilizada para referir-se ao local estabelecido dentro do congá, onde os médiuns ficam postos, enfileirados - formando uma linha, para trabalhar durante a gira.

Erê: Espírito de criança. São agrupados numa linha própria a Linha das Crianças e tem como líderes de falange Cosme e Damião.

Escora: Entidades pessoais da esquerda responsáveis pela proteção do médio.

Fazer a cabeça: Ritual feito para que o médio tenha firmeza ao receber as entidades e para que nenhum mal venha atrapalhar seu trabalho. Geralmente confirma a plena maturidade mediúnica, o fim do desenvolvimento

Gira: Denominação utilizada na umbanda para referir-se a culto ou a sessão religiosa.

Guia: Entidade espiritual, como por exemplo, preto-velho. Mas também pode referirse aos colares utilizados pelos médiuns que simbolizam as linhas espirituais da umbanda.

Pejí: É o mesmo que altar, espaço onde são colocadas as imagens de santos católicos e de outras entidades cultuadas na umbanda ou seus simbolos. Seu lugar no terreiro é a parede frontal da sala principal onde são realizadas as giras. Local sagrado na cultura afro-brasileira. Nem todos os guias são representados; cultuados neste lugar.

Receber o bastão: Termo utilizado por estes umbandistas, referindo-se a quem herdará a responsabilidade de dirigir o terreiro de umbanda como pai ou mãe-desanto. 
Trabalho: Oferenda ou seqüência ritual com um propósito específico. Por exemplo, quando algum guia pede para fazer algo no intuito de alcançar ou apressar um resultado desejado ou para desmanchar algum malefício.

Trato: Servir comidas, bebidas ou objetos de agrado das entidades durante a gira. $\mathrm{O}$ trato é um agrado para a entidade para que esta esteja sempre satisfeita e possa ajudar seus fiéis quando solicitada. São especificas para cada tipo ou classe de entidade e entende-se que essas oferendas, uma vez em posse das entidades, se transformam em meios para que elas possam trabalhar. Cada tipo de oferenda tem significados diversos, geralmente não revelados.

Tronqueira: Local fechado do terreiro, reservado para o culto á esquerda e onde entre outras coisas ficam imagens de exus e de pombas-gira. Apenas as pessoas de dentro do terreiro, como mãe-de-santo e médiuns, podem ter acesso. 
ANEXOS 
ANEXO 1 - TERMO DE CONSENTIMENTO APÓS INFORMAÇÃO 
TERMO DE CONSENTIMENTO APÓS INFORMAÇÃO

Pesquisa em Psicologia Social

Título: Os Exus da Umbanda: Inclusão Social e Narração Umbandista

Pesquisador: Flávia Andréa Pasqualin

Orientador: José Francisco Miguel Henriques Bairrão

\section{INFORMAÇÕES DADAS AOS COLABORADORES:}

Solicito a sua colaboração para uma pesquisa que tem o intuito de entender como as entidades denominadas "exus" se inserem na vida social e psicológica de médiuns, do terreiro e da sociedade. Pretende-se construir um retrato fiel desta entidade inserida no contexto geral de sua religião, assim como compreender em que medida suas características coincidem com a figura do brasileiro marginalizado. Assim, peço a sua autorização para acompanhar, observar e registrar (à mão, com gravador ou com filmadora) entrevistas, aspectos da sua vida pessoal e religiosa e a vida cotidiana do "centro", conforme for combinado previamente por nós. Haverá um único risco, mínimo, relacionado a esta pesquisa. Este risco é o que possa resultar de uma maior divulgação da sua religião e da sua "casa" no meio científico, pois os resultados deste trabalho serão divulgados publicamente em revistas especializadas ou outras formas de publicação. De qualquer forma, o seu anonimato e o da comunidade serão preservados, se assim desejar. Partimos da aposta de que o estudo das entidades "exus" será útil para a compreensão de aspectos sociais e psicológicos do indivíduo marginalizado socialmente. Solicito também a sua autorização para que os registros obtidos possam ser consultados por pesquisadores vinculados ao Laboratório de Etnopsicologia da FFCLRP e utilizados, se for o caso, nas pesquisas que eles desenvolvem, as quais seguem os mesmos critérios éticos aqui expostos, já que tanto este trabalho como os deles fazem parte de um mesmo programa de pesquisa psicológica sobre a umbanda e a espiritualidade brasileira.

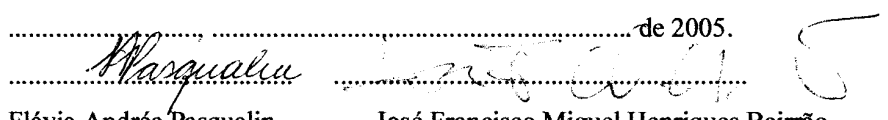

Flávia Andréa Pasqualin José Francisco Miguel Henriques Bairrão

Av. Bandeirantes 3900 - Ribeirão Preto - SP

Tel. (0xx 16)6023808 
Eu, foana Darc Gomes da dilva, RG: 28.720.814-x, médium ou pai/ mãe de santo do(a) Lenda espirita Unbanda Pai Benedito apos esclarecido pelo pesquisador sobre os objetivos e procedimentos da pesquisa a ser desenvolvida com médiuns e com entidades "exus" para o entendimento sobre a marginalidade no contexto umbandista, tendo recebido a garantia de que os procedimentos de registro das informações só serão realizados com a minha prévia autorização, podendo ser interrompidos a qualquer momento, se assim eu desejar, assim como poderei determinar o que não será divulgado, além da garantia de obter a resposta para qualquer pergunta ou esclarecimento sobre os procedimentos, riscos, benefícios e outros assuntos relacionados com a pesquisa, declaro-me de acordo em participar desse estudo, autorizando o pesquisador a observar, interagir e a entrevistar a mim e às entidades "exus" que comigo trabalham. Em sendo o caso de eu ser pai ou mãe de santo, portanto responsável pela condução espiritual de uma comunidade umbandista, autorizo-o a freqüentar e desenvolver a pesquisa no terreiro por mim dirigido, podendo entrevistar a mim, os médiuns da casa e suas entidades, mediante prévio entendimento com os mesmos.

Estou certo de que, embora a interpretação dos dados e a publicação dos resultados sejam da responsabilidade do pesquisador, nada será feito que possa me prejudicar ou à minha religião. Sei também que não serão divulgadas as informações obtidas sem minha autorização ou das entidades envolvidas. $O$ pesquisador comprometeu-se a não desenvolver nenhuma atividade que possa causar danos psíquicos ou sociais nem a mim nem aos demais membros da comunidade umbandista.

Por fim, o pesquisador compromete-se a me manter a par dos resultados em primeira mão e assina comigo este documento, em duas vias, uma delas permanecendo comigo.

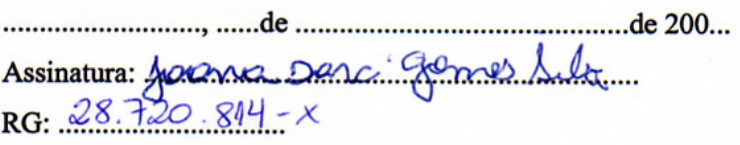


ANEXO 2 - NORMAS PARA MÉDIOS 
Segunda-feira - Preto Velho fazer banho de:

(Rosa branca) (rosa branca, arruda e guiné)

Quarta-feira - Caboclo fazer banho de:

(Arruda, alecrim e guiné ) (folha de pitanga )

Sexta-feira - Baiano fazer banho de:

São 7 ervas

Espada de São Jorge ( uma folha cortar em 7 pedaços )

alho 3 dentes

fumo 3 pedaços

coco seco 3 pedaços

arruda 3 folhas

guiné 3 folhas

alecrim 3 folhas

samambaia 3 folhas

Todo primeiro Domingo do mês - tem que trabalhar no Centro com Cosme e Damião.

Todo segundo Sábado do mês - tem que trabalhar no Centro com Cigano.

Toda terça-feira - irá ter trabalho de esquerda (apenas os médiuns).

Todo médium - deve fazer e tomar o banho de descarrego antes de ir trabalhar no centro.

Todo médium - deve cantar os pontos no trabalho.

Levar 7 velas de 7 dias - ( 4 brancas e 3 vermelhas) para firmar a sua escora.

Pagar a mensalidade de R\$20,00 - para ajudar com as despesas do centro, caso o

médium não tenha condição de pagar em dinheiro, deverá ajudar através de trabalho.

Defumação do dia de trabalho

(Incenso, Alfazema, Benjoim, Folha de Loro, Cravo, Nos Moscada, Canela em Pau, Breu, Mirra, Açúcar Cristal).

Defumação

(Arruda, Alecrim, Guiné, Folha de Laranjeira, Folha de Coqueiro, Folha de Eucalipto, Folha de Café, Folha de Uva, Pimenta Calabresa, Azeite de Dendê, Chifre)

Defumação de Domingo (Cosme e Damião)

(Açúcar Cristal, Coco Ralado, Cravo, Canela em Pau, Erva Doce, Flor de Laranjeira, Nos Moscada, Rosa Branca).

Material utilizado no centro para trabalho:

(Velas, Carvão, Giz, Charutos, Cigarro filtro Branco e Vermelho, Fumo, Coco Seco, Cerveja, Pinga, Champagne, Martini, Conhaque, Whisky, Vodka, Batida de Coco, Vinho Tinto Suave, Vinho Branco Suave, Niger, Guaraná, Copo Descartável, Pólvora, Caneta, Caderno) (Água Benta, Água de Mina, Água de Mar, Creolina, Folhagens - arruda, guine, alecrim, folha de laranjeira, folha de samambaia, Milho de Pipoca) (Energia, Água, IPTU, Pano de Chão, Vassoura, Rodo, Balde, Sabão em Pó, Cera, Lâmpada).

Quando chegar no Centro para trabalho o médio deve:

(Bater a cabeça no altar 3 vezes, bater a cabeça no chão em frete 0 altar, bater a cabeça no Pé da Mãe de Santo, ascender uma vela para o Anjo de Guarda fazendo uma Prece, pedir Bença para Mãe de Santo e para a Mãe Pequena, depois sentar, fazer silêncio a aguarda o início dos trabalhos)

Quando acabar o trabalho o médio deve:

(Bater a cabeça no altar 3 vezes, bater a cabeça no chão em frente 0 altar, pedir Bença para a Mãe de Santo, salvar os outros médiuns e salvar a Tabaca)

Cada médium será responsável pôr uma determinada área no Centro. 